Prepared in cooperation with the U.S. Environmental Protection Agency

\title{
Characterization of Mercury Contamination in the Androscoggin River, Coos County, New Hampshire
}

Open-File Report 2013-1076 
THIS PAGE INTENTIONALLY LEFT BLANK 


\section{Characterization of Mercury Contamination in the Androscoggin River, Coos County, New Hampshire}

By Ann T. Chalmers, Mark C. Marvin-DiPasquale, James R. Degnan, James F. Coles, Jennifer L. Agee, and Darryl Luce

Prepared in cooperation with the U.S. Environmental Protection Agency

Open-File Report 2013-1076 


\title{
U.S. Department of the Interior SALLY JEWELL, Secretary
}

\section{U.S. Geological Survey Suzette M. Kimball, Acting Director}

\author{
U.S. Geological Survey, Reston, Virginia: 2013
}

For more information on the USGS - the Federal source for science about the Earth, its natural and living resources, natural hazards, and the environment, visit http://www.usgs.gov or call 1-888-ASK-USGS.

For an overview of USGS information products, including maps, imagery, and publications, visit http://www.usgs.gov/pubprod

To order this and other USGS information products, visit http://store.usgs.gov

Any use of trade, firm, or product names is for descriptive purposes only and does not imply endorsement by the U.S. Government.

Although this information product, for the most part, is in the public domain, it also may contain copyrighted materials as noted in the text. Permission to reproduce copyrighted items must be secured from the copyright owner.

Suggested citation:

Chalmers, A.T., Marvin-DiPasquale, M.C., Degnan, J.R., Coles, J.F., Agee, J.L., and Luce, Darryl, 2013, Characterization of mercury contamination in the Androscoggin River, Coos County, New Hampshire: U.S. Geological Survey Open-File Report 2013-1076, 56 p., http://pubs.usgs.gov/of/2013/1076/. 


\section{Acknowledgments}

The authors would like to thank the many individuals that provided field and laboratory support for this project. Andrew Hoffman of the New Hampshire Department of Environmental Services (NHDES), Vivien Taylor of Dartmouth College, and Cornell Rosiu of the U.S. Environmental Protection Agency (USEPA) assisted with sediment collection; Chuck Dobroski of Avatar Environmental, Kenneth Munney of the U.S. Fish and Wildlife Service, and Stan Pauwels of the USEPA collected fish samples; David Buck of BioDiversity Research Institute collected bat samples; and Michael Ferrier, Erica Czerepak, and Bethany Kelley of USEPA Region 1 Environmental Services Assistance Team (ESAT) collected oligochaete, swallow, and toxicity samples and processed the surface and pore-water toxicity samples.

Thor Smith of the U.S. Geological Survey (USGS) assisted with surface-water, pore-water, and invertebrate sampling. Marc Zimmerman, Jon Denner, and Jamie Shanley of the USGS assisted with pore-water sample collection, and Evangelos Kakouros, Le Kieu, and Michelle Beyer of the USGS analyzed pore-water and sediment samples. Jeffrey Deacon of the USGS and Cornell

Rosiu of the USEPA were instrumental in the study planning and design. The authors would also like to thank Chuck Dobroski and Jamie Shanley for their thoughtful technical reviews. 
THIS PAGE INTENTIONALLY LEFT BLANK 


\section{Contents}

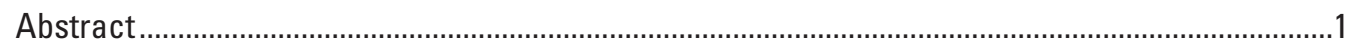

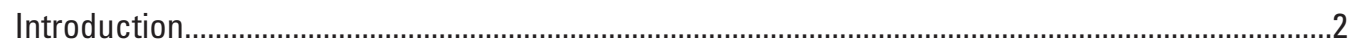

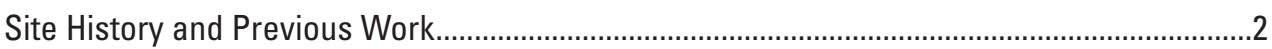

Purpose and Scope .......................................................................................................

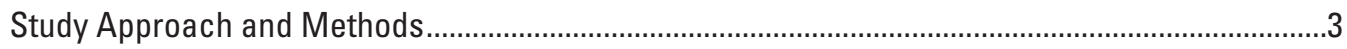

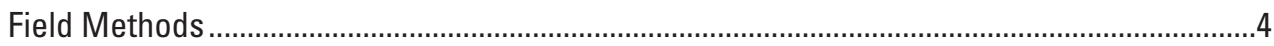

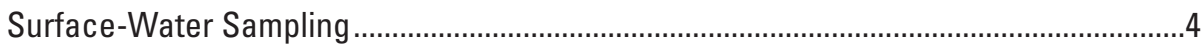

Sediment Pore-Water Sampling.................................................................................

Streambed-Sediment Sampling ...................................................................................

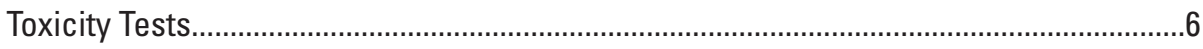

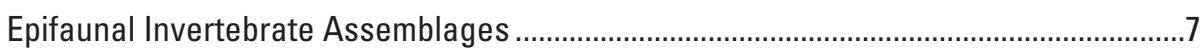

Infaunal Invertebrate Tissue .............................................................................................

White Sucker, Smallmouth Bass, and Crayfish..............................................................

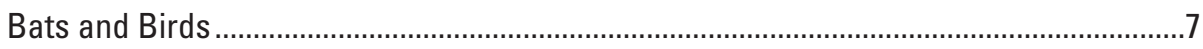

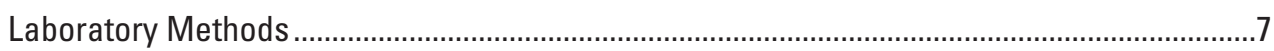

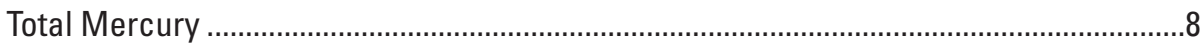

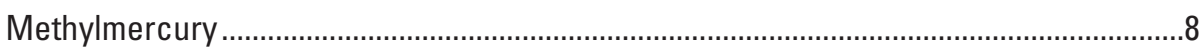

Reactive Inorganic Mercury ...................................................................................

Methylmercury Production Potential and Microbial Divalent-Mercury-Methylation Rate Constant................................................................................................

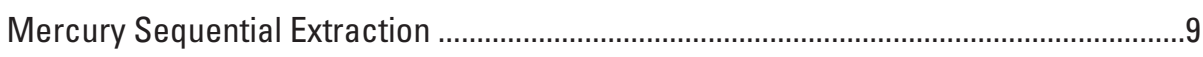

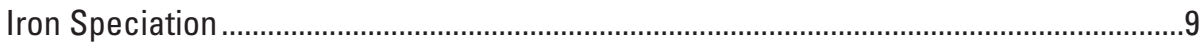

Total Reduced Sulfur .................................................................................................

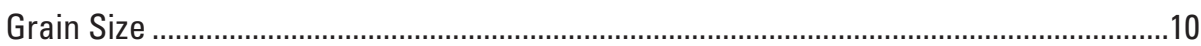

Dry Weight, Bulk Density, Porosity, and Organic Content ............................................10

Total and Organic Carbon, Total Nitrogen, and Carbon and Nitrogen Isotopes..............10

Pore-Water Dissolved Organic Carbon......................................................................10

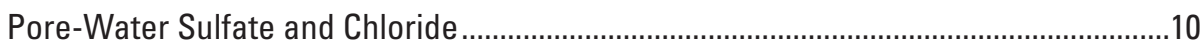

Pore-Water Ferrous Iron ...............................................................................................10

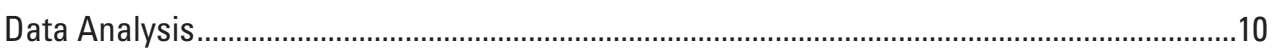

Results and Discussion......................................................................................................11

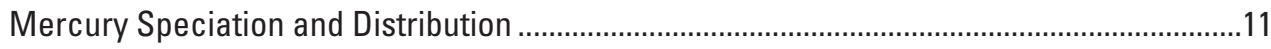

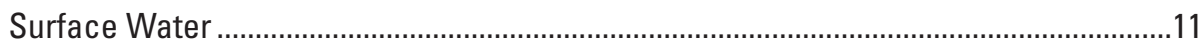

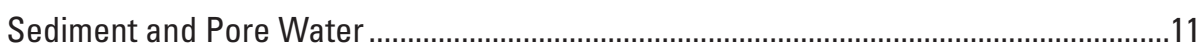

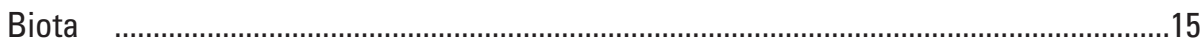

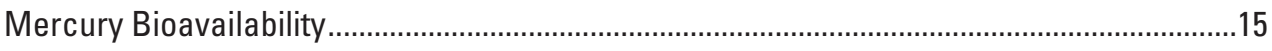

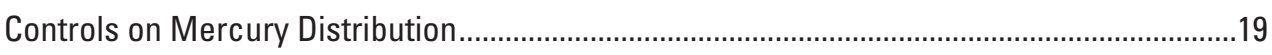

Controls on Divalent Mercury Availability for Methylation...................................................23

Controls on Partitioning between Bed Sediment and Pore Water........................................23

River-Reach Integrated Mercury Species Inventories and Methylmercury Production

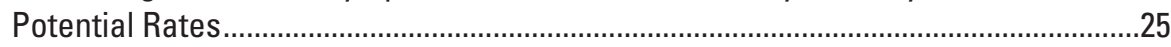

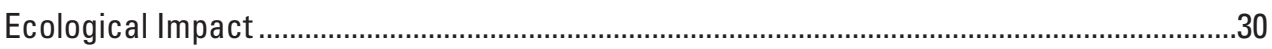

Comparison to Other Studies.................................................................................................33 
Summary and Conclusions..........................................................................................................

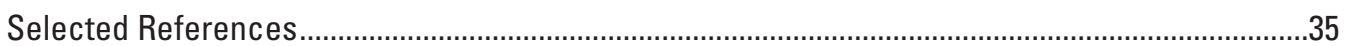

Appendix 1. Quality Assurance and Control at the U.S. Geological Survey Laboratory in

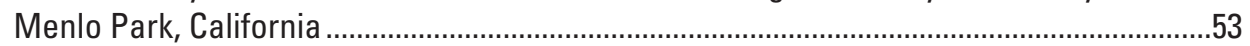

Appendix 2. Surface-Water, Pore-Water, Sediment, Invertebrate, and Biota Data......................55

\section{Figures}

1. Graph showing generalized locations of sediment and pore-water sampling sites on the Androscoggin River downstream from a former chloralkali facility in Berlin, New Hampshire

2. Map of study area on the Androscoggin River, Coos County, New Hampshire.................5

3. Boxplots showing concentrations of sediment $A$, total mercury $(\mathrm{THg}), B$, methylmercury $(\mathrm{MeHg}$ ), and $C$, percentage of $\mathrm{THg}$ as $\mathrm{MeHg}$ from the Androscoggin River, Coos County, New Hampshire....

4. Boxplots showing concentrations of pore-water $A$, total mercury (pw.THg), $B$, methylmercury (pw.MeHg), and $C$, percentage of $\mathrm{THg}$ as $\mathrm{MeHg}$ (pw\% $\mathrm{MeHg}$ ) from the Androscoggin River, Coos County, New Hampshire.

5. Boxplots showing concentrations of $A$, dissolved organic carbon (pw.DOC) and $B$, sediment loss on ignition (LOI) from the Androscoggin River, Coos County, New Hampshire.....

6. Boxplots showing mercury partitioning coefficients from the Androscoggin River, Coos County, New Hampshire

7. Bar graph showing sequential extractions of surficial sediment in the Androscoggin River, Coos County, New Hampshire.

8. Boxplots showing concentrations of total mercury (THg) in $A$, smallmouth bass and

$B$, white sucker from the Androscoggin River, Coos County, New Hampshire.

9. Boxplot showing concentrations of total mercury $(\mathrm{THg})$ in smallmouth bass from the Androscoggin River

10. Boxplots showing sediment mercury methylation potential from the Androscoggin

River, Coos County, New Hampshire.....

11. Boxplots showing concentrations of $A$, pore-water sulfate $\left(\mathrm{pw}^{-\mathrm{SO}_{4}^{-2}}\right)$ and $B$, sediment total reduced sulfur (TRS) from the Androscoggin River, Coos County, New Hampshire .....

12. Boxplots showing $A$, sediment grain size less than 63 micrometers $(\mu \mathrm{m})$ and $B$, oxidation reduction potential (redox, $\mathrm{E}_{\mathrm{h}}$ ) from the Androscoggin River, Coos County, New Hampshire.

13. Graphs showing predicted against measured sediment total mercury $(\mathrm{THg})$ for $A$, near, $B$, far, and $C$, all stream reaches of the Androscoggin River, Coos County, New Hampshire ......

14. Graph showing predicted against measured methylmercury (MeHg) from the Androscoggin River, Coos County, New Hampshire

15. Graphs showing predicted against measured sediment inorganic reactive mercury $\left(\mathrm{Hg}(\mathrm{II})_{\mathrm{R}}\right)$ for $A$, near, $B$, far, and $C$, all stream reaches of the Androscoggin River, Coos County, New Hampshire.

16. Graphs showing predicted against measured mercury methylation potential (MPP) $A$, constant $\left(\mathrm{k}_{\text {meth }}\right)$ and $B$, rate for the Androscoggin River, Coos County, New Hampshire 
17. Graphs showing predicted against measured partitioning coefficient for $A$, total mercury $\left(\mathrm{k}_{\mathrm{d}}[\mathrm{THg}]\right)$ and $B$, methylmercury $\left(\mathrm{k}_{\mathrm{d}}[\mathrm{MeHg}]\right)$ for the Androscoggin River, Coos County, New Hampshire.....

18. Graph showing sediment total mercury partitioning coefficient as a function of dissolved organic carbon and grain size

19. Graph showing sediment methylmercury partitioning coefficient as a function of dissolved organic carbon and grain size

20. Bar graph showing New Hampshire Department of Environmental Services (NHDES) benthic index of biotic integrity (B-IBI) for the Androscoggin River, Coos County, New Hampshire

\section{Tables}

1. Study sampling area description and dates for the Androscoggin River from Pontook Reservoir to Shelburne Dam, New Hampshire..

2. Summary of methods used for analysis of sediment, pore water, surface water, and biota from the Androscoggin River, Coos County, New Hampshire

3. Sequential extraction scheme applied to surface sediment samples from the Androscoggin River, Coos County, New Hampshire.

4. Wilcoxon rank sum test comparing results upstream and downstream from a former chloralkali site on the Androscoggin River in Berlin, New Hampshire

5. Kruskal-Wallis rank sum test results comparing data grouped by sample distance from a former chloralkali site on the Androscoggin River in Berlin, New Hampshire....47

6. Sequential extraction results for surface sediment, Androscoggin River, Coos County, New Hampshire

7. Stream reach parameters used to calculate reach specific depth integrated mercury species inventories and rates . .30

8. Depth-integrated mercury species inventories and rates, by river reach .......................31

9. Guidelines for total mercury in surface water, sediment, and fish and methylmercury in surface water

10. Comparison of mercury concentrations in the Androscoggin River, Coos County, New Hampshire, with National Water-Quality Assessment Program and Northeastern Ecosystem Research Cooperative datasets 


\section{Conversion Factors and Datum}

SI to Inch/Pound

\begin{tabular}{|c|c|c|}
\hline Multiply & By & To obtain \\
\hline \multicolumn{3}{|c|}{ Length } \\
\hline centimeter $(\mathrm{cm})$ & 0.3937 & inch (in.) \\
\hline meter $(\mathrm{m})$ & 3.281 & foot $(\mathrm{ft})$ \\
\hline kilometer (km) & 0.6214 & mile (mi) \\
\hline meter $(\mathrm{m})$ & 1.094 & yard $(y d)$ \\
\hline \multicolumn{3}{|c|}{ Area } \\
\hline square meter $\left(\mathrm{m}^{2}\right)$ & 0.0002471 & acre \\
\hline square meter $\left(\mathrm{m}^{2}\right)$ & 10.76 & square foot $\left(\mathrm{ft}^{2}\right)$ \\
\hline square centimeter $\left(\mathrm{cm}^{2}\right)$ & 0.1550 & square inch $\left(\mathrm{ft}^{2}\right)$ \\
\hline square kilometer $\left(\mathrm{km}^{2}\right)$ & 0.3861 & square mile $\left(\mathrm{mi}^{2}\right)$ \\
\hline \multicolumn{3}{|c|}{ Mass } \\
\hline kilogram (kg) & 2.205 & pound avoirdupois (lb) \\
\hline \multicolumn{3}{|c|}{ Hydraulic gradient } \\
\hline meter per kilometer $(\mathrm{m} / \mathrm{km})$ & 5.27983 & foot per mile ( $\mathrm{ft} / \mathrm{mi})$ \\
\hline
\end{tabular}

In this report, the words right and left refer to directions that would be reported by an observer facing downstream.

Vertical coordinate information is referenced to the North American Vertical Datum of 1988 (NAVD 88).

Horizontal coordinate information is referenced to the North American Datum of 1983 (NAD 83).

Altitude, as used in this report, refers to distance above the vertical datum.

Concentrations of chemical constituents in water are either in milligrams per liter $(\mathrm{mg} / \mathrm{L})$, micrograms per liter ( $\mu \mathrm{g} / \mathrm{L})$, nanograms per liter $(\mathrm{ng} / \mathrm{L})$, moles per liter $(\mathrm{M})$, or millimoles per liter (mmol/L). 


\title{
Characterization of Mercury Contamination in the Androscoggin River, Coos County, New Hampshire
}

\author{
By Ann T. Chalmers', Mark C. Marvin-DiPasquale', James R. Degnan', James F. Coles' ${ }^{1}$, Jennifer L. Agee', and \\ Darryl Luce ${ }^{2}$
}

\section{Abstract}

The former chloralkali facility in Berlin, New Hampshire, was designated a Superfund site in 2005. Historic paper mill activities resulted in the contamination of groundwater, surface water, and sediments with many organic compounds and mercury $(\mathrm{Hg})$. $\mathrm{Hg}$ continues to seep into the Androscoggin River in elemental form through bedrock fractures. The objective of this study was to spatially characterize (1) the extent of $\mathrm{Hg}$ contamination in water, sediment, and biota; (2) $\mathrm{Hg}$ speciation and methylmercury $(\mathrm{MeHg}$ ) production potential rates in sediment; (3) the availability of inorganic divalent $\mathrm{Hg}(\mathrm{Hg}(\mathrm{II}))$ for $\mathrm{Hg}(\mathrm{II})$-methylation ( $\mathrm{MeHg}$ production); and (4) ancillary sediment geochemistry necessary to better understand $\mathrm{Hg}$ speciation and $\mathrm{MeHg}$ production potential rates in this system.

Concentrations of total mercury (THg) and $\mathrm{MeHg}$ in sediment, pore water, and biota in the Androscoggin River were elevated downstream from the former chloralkali facility compared with those upstream from reference sites. Sequential extraction of surface sediment showed a distinct difference in $\mathrm{Hg}$ speciation upstream compared with downstream from the contamination site. An upstream site was dominated by potassium hydroxide-extractable forms (for example, organic-Hg or particle-bound $\mathrm{Hg}(\mathrm{II})$ ), whereas sites downstream from the point source were dominated by more chemically recalcitrant forms (largely concentrated nitric acid-extractable), indicative of elemental mercury or mercurous chloride. At all sites, only a minor fraction (less than 0.1 percent) of THg existed in chemically labile forms (for example, water extractable or weak acid extractable). All metrics indicated that a greater percentage of mercury at an upstream site was available for $\mathrm{Hg}(\mathrm{II})$-methylation compared

${ }^{1}$ U.S. Geological Survey.

${ }^{2}$ U.S. Environmental Protection Agency. with sites downstream from the point source, but the absolute concentration of bioavailable $\mathrm{Hg}(\mathrm{II})$ was greater downstream from the point source. In addition, the concentration of tinreducible inorganic reactive mercury, a surrogate measure of bioavailable $\mathrm{Hg}$ (II) generally increased with distance downstream from the point source. Whereas concentrations of mercury species on a sediment-dry-weight basis generally reflected the relative location of the sample to the point source, river-reach integrated mercury-species inventories and $\mathrm{MeHg}$ production potential (MPP) rates reflected the amount of finegrained sediment in a given reach.

THg concentrations in biota were significantly higher downstream from the point source compared with upstream reference sites for smallmouth bass, white sucker, crayfish, oligochaetes, bat fur, nestling tree swallow blood and feathers, adult tree swallow blood, and tree swallow eggs. As with tin-reducible inorganic reactive mercury, $\mathrm{THg}$ in smallmouth bass also increased with distance downstream from the point source. Toxicity tests and invertebrate community assessments suggested that invertebrates were not impaired at the current (2009 and 2010) levels of mercury contamination downstream from the point source. Concentrations of $\mathrm{THg}$ and $\mathrm{MeHg}$ in most water and sediment samples from the Androscoggin River were below U.S. Environmental Protection Agency (USEPA), the Canadian Council of Ministers of the Environment, and probable effects level guidelines. Surfacewater and sediment samples from the Androscoggin River had similar THg concentrations but lower MeHg concentrations compared with other rivers in the region. Concentrations of THg in fish tissue were all above regional and U.S. Environmental Protection Agency guidelines. Moreover, median THg concentrations in smallmouth bass from the Androscoggin River were significantly higher than those reported in regional surveys of river and streams nationwide and in the Northeastern United States and Canada. The higher concentrations of mercury in smallmouth bass suggest conditions may be more favorable for $\mathrm{Hg}$ (II)-methylation and bioaccumulation in the Androscoggin River compared with many other rivers in the United States and Canada. 


\section{Introduction}

During operation of the chloralkali facility in Berlin, New Hampshire, elemental mercury $\left(\mathrm{Hg}^{0}\right)$ was spilled contaminating the overburden and underlying fractured rock on the east (left) bank of the Androscoggin River. $\mathrm{Hg}^{0}$ is relatively nontoxic; the primary pathway of $\mathrm{Hg}^{0}$ toxicity in the environment begins with the oxidation to inorganic divalent mercury $(\mathrm{Hg}(\mathrm{II}))$ in the presence of chloride, thiol compounds, and oxygen. In low salinity waters such as those of the Androscoggin River, $\mathrm{Hg}^{0}$ oxidation is quite slow, and formation of oxidation products on the surface of the liquid further reduces oxidation rates (Amyot and others, 2005). The conversion of $\mathrm{Hg}(\mathrm{II})$ to more bioavailable methylmercury $(\mathrm{MeHg})$ is a process that is largely carried out by anaerobic bacteria near the sediment-water interface (Gilmour and others, 1992). Rates of net benthic MeHg production in the sediments are controlled by the activity of the $\mathrm{Hg}(\mathrm{II})$ methylating microbial community and by $\mathrm{Hg}(\mathrm{II})$ availability to microbes (Marvin-DiPasquale and others, 2009a). Environmental factors that affect the activity of communities of $\mathrm{Hg}(\mathrm{II})$-methylating bacteria include temperature, $\mathrm{pH}$, and presence of suitable electron acceptors and donors. Availability of $\mathrm{Hg}$ (II) to microbes is controlled by total mercury (THg) concentration, dissolved organic carbon (DOC), sediment grain size, and calcium, iron, and sulfur solid-phase mineral chemistry. Understanding the $\mathrm{Hg}(\mathrm{II})$ processes and the environments that are conducive to methylation will provide key information for remedial actions and decisions.

\section{Site History and Previous Work}

In September 2005, Congress added the former chloralkali facility in Berlin, N.H., to the national priorities list, commonly known as the Superfund list (U.S. Environmental Protection Agency, 2005). Investigations onsite have revealed elevated mercury, lead, arsenic, polycyclic aromatic hydrocarbons, organochlorine chemicals (dioxin and furans, polychlorinated biphenyls), and other toxic metals in groundwater and soils (Darryl Luce, U.S. Environmental Protection Agency (USEPA), written commun., 2008). The mercury contamination originates from two longstanding point sources across from one another on the Androscoggin River in Berlin, N.H. A chloralkali facility that produced chlorine gas for the papermaking industry using electrolytic diaphragm cells operated from the late 1800s through the 1960s (Margaret Bastien, New Hampshire Department of Environmental Services (NHDES), written commun., 2004). How mercury was used at the facility is uncertain. Mercury may have been used in the cells to separate chlorine from a brine solution. The second source of mercury was from a sawmill that used mercuric chloride wood preserving process known as kyanization. Kyanization was used by the sawmill from 1888 through 1930 (Weston Solutions, 2005). The mercuric chloride may have been prepared at the chloralkali facility and then transported across the river for use at the kyanization plant. Regardless of use, the main release of mercury to the environment was at the chloralkali facility on the left bank of the Androscoggin River, just downstream from Sawmill Dam (fig. 1). The total amount of mercury released from the facility that seeped into the overburden and into the underlying fractured bedrock is unknown (Degnan and others, 2005). Efforts to contain the mercury at the chloralkali site and eliminate seepage to the river include demolition of the cell houses, installation of a bentonite-soil slurry barrier wall on the site perimeter, and pressure grouting the bedrock along the riverbank (Margaret Bastien, NHDES, written commun., 2003). Despite earlier actions to address the source of contamination, mercury continues to seep into the Androscoggin River through fractures in the bedrock at the edge of the site (Darryl Luce, USEPA, written commun., 2008). Mercury has also been found in the sediment of the adjacent Androscoggin River from sampling conducted by the former site owners and the NHDES (Darryl Luce, USEPA, written commun., 2008). THg concentrations (average plus or minus standard deviation) in sediments collected at dam impoundments by the NHDES (Lori Siegel, NHDES, written commun., 2004) were highly variable, from $75 \pm 177$ nanograms per gram (ng/g) at Sawmill Dam (upstream from the facility) to $361 \pm 483 \mathrm{ng} / \mathrm{g}$ at Riverside Dam and $354 \pm 277 \mathrm{ng} / \mathrm{g}$ at Smith Hydro Dam (both downstream from the facility). MeHg concentrations in sediments collected by the NHDES were lowest at Sawmill Dam $(0.071 \pm 0.082 \mathrm{ng} / \mathrm{g})$ and higher at Smith Hydro Dam $(1.00 \pm 0.79 \mathrm{ng} / \mathrm{g})$ and Riverside Dam (1.28 $\pm 2.16 \mathrm{ng} / \mathrm{g})$. Subsequently, further investigation into the extent of mercury contamination and transformation processes within the Androscoggin River was deemed warranted by the USEPA to determine the potential impacts on the environment and to provide a more comprehensive understanding of mercury dynamics in this system to guide potential remediation activities. To that end, the USEPA funded a study conducted by the U.S. Geological Survey (USGS) from 2009 through 2012 to provide more detailed information regarding the extent of mercury contamination and speciation within the Androscoggin River. The major objectives of this study were to characterize the extent of mercury contamination in sediment, water, and biota of the Androscoggin River and to assess mercury speciation and the potential availability of in-situ mercury for $\mathrm{Hg}(\mathrm{II})$-methylation.

\section{Purpose and Scope}

This report (1) compares surface-water, pore-water, sediment, and biota $\mathrm{THg}$ and $\mathrm{MeHg}$ concentrations upstream and downstream from a former chloralkali facility; (2) evaluates the potential for $\mathrm{Hg}(\mathrm{II})$-methylation and mercury bioaccumulation; (3) explains differences in $\mathrm{MeHg}$ production rates and bioavailable $\mathrm{Hg}(\mathrm{II})$ patterns among sites using nonparametric rank sum tests and best-fit linear model equations; (4) assesses the health of the aquatic ecosystem surrounding the former chloralkali facility using a variety of surface-water, sediment, 


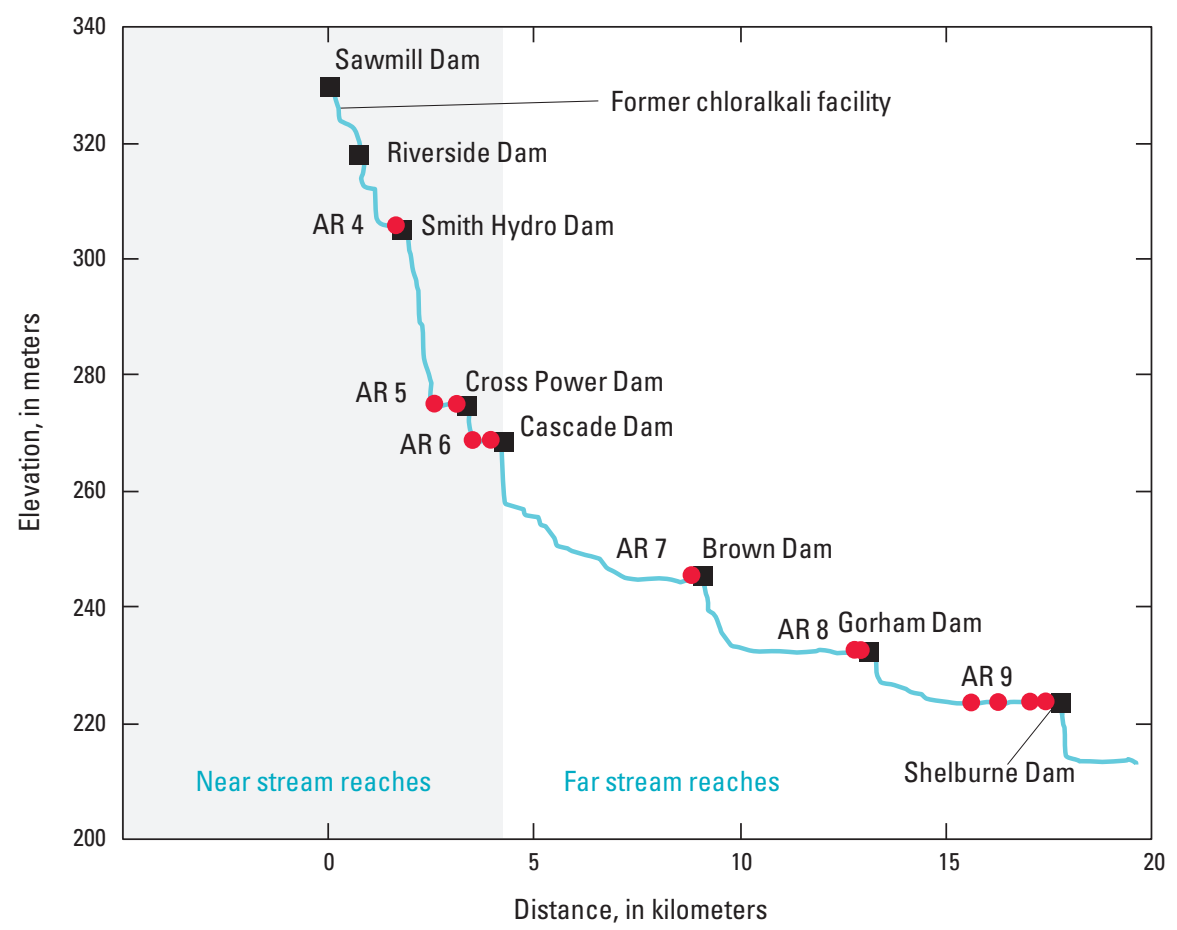

Figure 1. Generalized locations of sediment and pore-water sampling sites on the Androscoggin River downstream from a former chloralkali facility in Berlin, New Hampshire. Stream reaches are signified by AR followed by number. The reference reach (AR2) is 16 kilometers upstream from the former chloralkali facility and is not shown. Sampling locations are indicated by red circles, dams are indicated by black squares. Elevation and distance data from Google Earth, February 17, 2012.

and biological indices and guidelines; and (5) compares $\mathrm{THg}$ and $\mathrm{MeHg}$ concentrations in water, sediment, and biota from the study site to concentrations reported in other river systems nationally and regionally in the Northeastern United States and Canada.

In addition, this report also summarizes concurrent biomonitoring data collected by BioDiversity Research Institute (Gorham, Maine) and Avatar Environmental (West Chester, Pennsylvania) contracted by the USEPA for the purposes of providing additional context regarding the human health and ecological impacts of mercury within the study area.

\section{Study Approach and Methods}

The study area encompasses a 40-kilometer $(\mathrm{km})$ reach of the Androscoggin River from Pontook Reservoir to just upstream from Shelburne Dam, including the former chloralkali facility site in Berlin (table 1, fig. 2). Individual river reaches (coded as AR followed by the number of the reach\#) were defined by the presence of dam structures at the upper and lower boundary of each reach. The precise coordinates for all sampling locations are listed in table 2-1. Pontook
Reservoir (AR1) and Wheeler Bay (within the upper portion of AR2), both upstream from the facility, were used as reference sites of background (nonpoint-source) conditions. AR1 was used as a reference site for birds and bats, whereas AR2 was a reference site for sediment, pore water, surface water, epifaunal invertebrates, crayfish, and birds. Seven stream reaches, from the facility (within AR3) to just upstream from Shelburne Dam (AR9), were sampled to characterize the mercury contamination downstream from the point source.

$\mathrm{THg}$ and $\mathrm{MeHg}$ concentrations were analyzed in surface water, pore water, and sediment and THg in macroinvertebrates, crayfish, fish, bats, and birds (tables 1, A2-1). The potential for $\mathrm{Hg}(\mathrm{II})$-methylation and $\mathrm{MeHg}$ bioaccumulation was assessed by a number of different metrics. The percentage of $\mathrm{THg}$ as $\mathrm{MeHg}$ (percent $\mathrm{MeHg}$ ) in sediment was used as a proxy for $\mathrm{Hg}$ (II)-methylation efficiency. Tin-reducible reactive inorganic mercury $\left(\mathrm{Hg}(\mathrm{II})_{\mathrm{R}}\right)$ was used as a surrogate for the pool of inorganic $\mathrm{Hg}(\mathrm{II})$ readily available to sediment bacteria for $\mathrm{Hg}$ (II)-methylation. This methodologically defined assay measures simple $\mathrm{Hg}(\mathrm{II})$-salts, such as mercury sulfate and mercury chloride $\mathrm{Hg}$ (II) bound to low molecular weight organic ligands, and $\mathrm{Hg}$ (II) weakly adsorbed to particle surfaces (Marvin-DiPasquale and others, 2006; Marvin-DiPasquale, 
Table 1. Study sampling area description and dates for the Androscoggin River from Pontook Reservoir to Shelburne Dam, New Hampshire.

[Epifaunal invertebrates were collected in rock baskets]

\begin{tabular}{|c|c|c|c|}
\hline $\begin{array}{l}\text { Reach } \\
\text { code }\end{array}$ & Reach description & Sampling dates & Sample types \\
\hline AR1 & Above Pontook Dam & 2010 & Bat, bird \\
\hline AR2 & Pontook Dam to Wheeler Bay & 2009, 2010, 2011 & $\begin{array}{l}\text { Sediment, pore-water, surface-water, epifaunal inverte- } \\
\text { brate, oligochaetes, crayfish, fish, bird }\end{array}$ \\
\hline AR3 & Sawmill Dam to Riverside Dam & 2009,2010 & Surface-water, epifaunal invertebrate, crayfish, fish, bird \\
\hline AR4 & Riverside Dam to Smith Hydro Dam & 2009,2010 & $\begin{array}{l}\text { Sediment, pore-water, surface-water, epifaunal inverte- } \\
\text { brate, oligochaetes, crayfish, fish, bird }\end{array}$ \\
\hline AR5 & Smith Hydro Dam to Cross Power Dam & 2010,2011 & Sediment, pore-water, oligochaetes, crayfish, fish \\
\hline AR6 & Cross Power Dam to Cascade Dam & 2009, 2010, 2011 & Sediment, pore-water, oligochaetes, crayfish, fish \\
\hline AR7 & Cascade Dam to Brown Dam & 2010, 2011 & Sediment, pore-water, oligochaetes, crayfish, fish \\
\hline AR8 & Brown Dam to Gorham Dam & 2009,2010 & $\begin{array}{l}\text { Sediment, pore-water, surface-water, epifaunal inverte- } \\
\text { brate, oligochaetes, crayfish, fish, bird }\end{array}$ \\
\hline AR9 & Gorham Dam to Shelburne Dam & 2009,2010 & $\begin{array}{l}\text { Sediment, pore-water, surface-water, epifaunal inverte- } \\
\text { brate, oligochaetes, crayfish, fish, bat, bird }\end{array}$ \\
\hline
\end{tabular}

unpub. data). Microbial MeHg production potential (MPP) rates were measured in sediment using ${ }^{200} \mathrm{Hg}(\mathrm{II})$ stable isotope incubations to measure the microbial rate constant for $\mathrm{Hg}(\mathrm{II})$ methylation $\left(\mathrm{k}_{\text {meth }}\right)$ and calculated based on $\mathrm{k}_{\text {meth }}$ and the independently measured $\mathrm{Hg}(\mathrm{II})_{\mathrm{R}}$ concentration (Marvin-DiPasquale and others, 2008). Another approach used to assess mercury availability was a five-step sequential extraction (Bloom and others, 2003) that chemically characterizes the THg pool from most labile (water-extractable) to most refractory (aqua regia-extractable). Site-specific differences in MPP rates were examined in terms of a suite of environmental factors, such as sediment redox conditions, particle size, sulfur and iron chemistry, and organic content in sediment, all of which can affect both the activity of $\mathrm{Hg}$ (II)-methylating bacteria and the availability of $\mathrm{Hg}$ (II) to those bacteria.

The potential biological impact of the mercury contamination in the study area was assessed by the community composition of epifaunal macroinvertebrate assemblages and toxicity testing of surface waters, pore waters, and bulk sediment. Surface-water, sediment, and biological indices and guidelines were also used to evaluate the potential ecological impact of the mercury contamination within the study area.

\section{Field Methods}

Field sampling was performed during 3 years (table 1). Samples were collected from a wide range of media during August and September 2009, including surface water, sediment pore water, whole sediment, fish, crayfish, epifaunal invertebrates, and infaunal invertebrates. Surface-water, sediment pore-water, and whole-sediment samples were collected by the USGS, fish and crayfish were collected by Avatar Environmental, and epifaunal invertebrates and infaunal invertebrates were collected by USGS and USEPA Region 1 Environmental Services Assistance Team (ESAT). During August 2010, USGS field sampling focused on mercury speciation and $\mathrm{Hg}$ (II)-methylation in sediment and on ancillary sediment parameters associated with carbon, iron, and sulfur. Additional biological sampling was conducted during 2010 and 2011 by BioDiversity Research Institute, ESAT, and the USEPA and included fish, infaunal invertebrates, bats, and marsh birds.

\section{Surface-Water Sampling}

Surface-water samples were collected during low streamflow conditions (average daily flow of 1,620 cubic feet per second) in September 2009 using multiple sampling points, based on standard USGS protocols (U.S. Geological Survey, 2005), and were processed using trace-metal clean techniques (Olson and DeWild, 1999). At wadeable sections of the river, samples were collected with a hand-held teflon depth integrating sampler (DH-81). At nonwadeable sections, samples were collected using an isokinetic sampler (D-95; equipped with a teflon nozzle and a teflon bottle) that was lowered from bridges using a reel and cable. Specific conductance, $\mathrm{pH}$, dissolved oxygen, and water temperature were determined during the collection of surface-water samples using a multiprobe sonde (YSI 600XL). Samples were filtered using 0.45-micrometer $(\mu \mathrm{m})$ high-capacity capsule filters. Both dissolved (filter passing) and total (nonfiltered) surfacewater samples were collected during 2009; $\mathrm{THg}$ and $\mathrm{MeHg}$ 


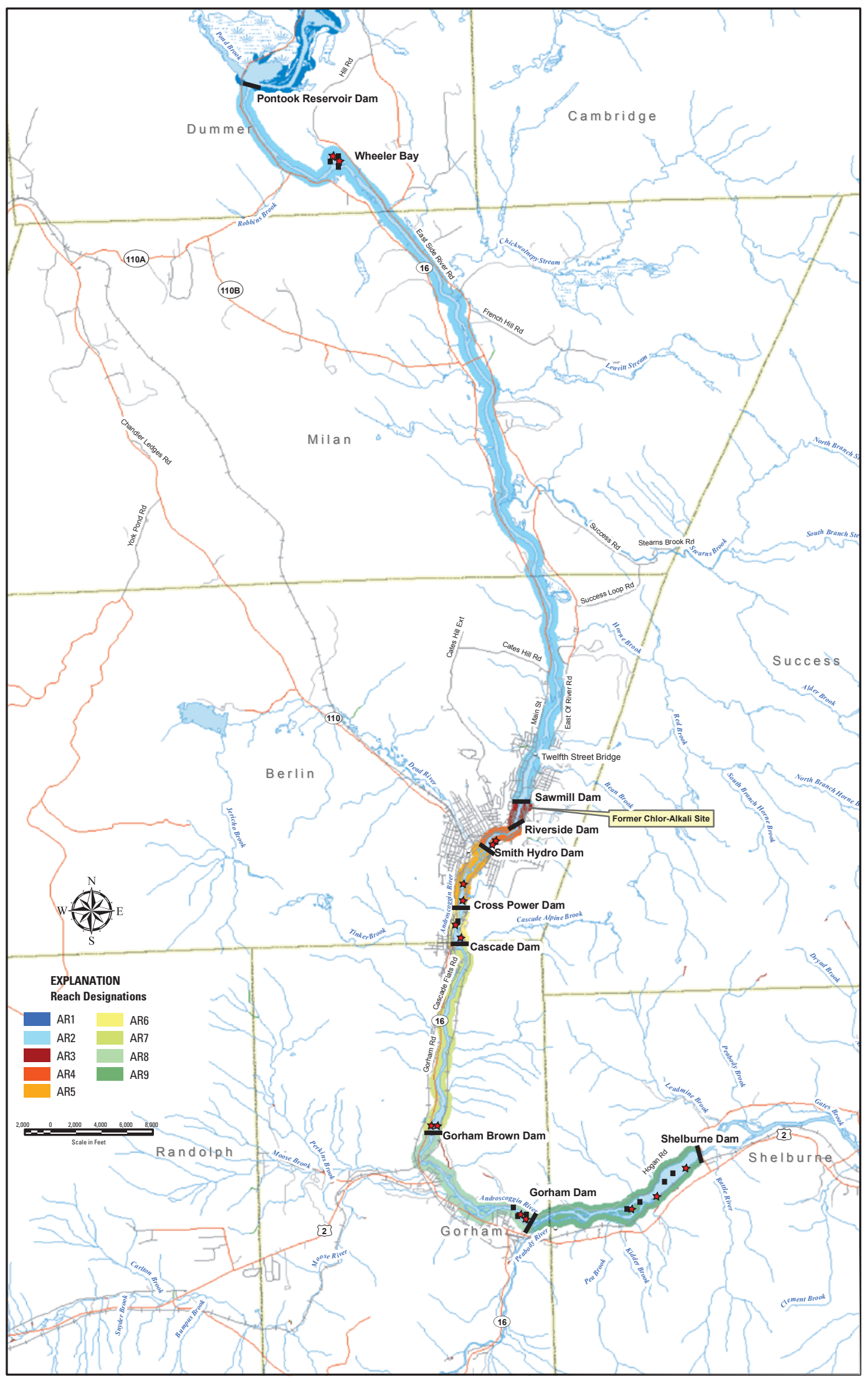

Base map prepared by AVATAR Environmental, LLC.

Figure 2. Map of study area on the Androscoggin River, Coos County, New Hampshire. Stream reaches are signified by AR followed by number. Pore-water and sediment sampling sites are black squares (2009) and red stars (2010). Base map prepared by AVATAR Environmental LCC. 
samples were preserved with hydrochloric acid to a $\mathrm{pH}$ of less than 2, total recoverable metals (antimony, arsenic, beryllium, cadmium, chromium, copper, lead, nickel, selenium, strontium, vanadium, and zinc) samples were preserved with nitric acid to a $\mathrm{pH}$ of less than 2 , and organic carbon samples were preserved with sulfuric acid to a $\mathrm{pH}$ of less than 2 . All samples were kept chilled in coolers with wet ice and then refrigerated upon return to the laboratory.

\section{Sediment Pore-Water Sampling}

Pore-water samples were collected in depositional areas of the stream channel, typically along the channel margins. Pore-water samples were obtained in-situ during low streamflow conditions during September 2009 and August 2010 using a push-point sampler as described in Zimmerman and others (2005) and were processed using trace-metal clean techniques (Olson and DeWild, 1999). A push-point sampler is designed to sample pore water with minimal disturbance to the sediment matrix. Specific conductance was used to monitor chemical differences between surface water and pore water during sampling and to verify that surface water was not drawn down into the pore-water sampling zone.

Other field parameters measured with the YSI 600XL multiprobe sonde included $\mathrm{pH}$, dissolved oxygen, oxidationreduction (redox) potential (ORP), and water temperature. ORP was measured with a platinum band electrode. Porewater samples were collected at depths between 7 and 15 centimeters $(\mathrm{cm})$ below the interface between the sediment and surface water using a peristaltic pump with teflon tubing. In-line filtration with $0.45-\mu \mathrm{m}$ high-capacity capsule filters was used during 2009 , and $0.4-\mu \mathrm{m}$ precombusted quartz-fiber filters in teflon filter assemblies were used during 2010. Both dissolved (filter passing) and nonfiltered pore-water samples collected during 2009 were preserved for THg and $\mathrm{MeHg}$ (pw.THg and pw.MeHg), total recoverable metals (antimony, arsenic, beryllium, cadmium, chromium, copper, lead, nickel, selenium, strontium, vanadium, and zinc), and dissolved organic carbon (pw.DOC), as described above for surface water. All samples collected during 2010 were filtered and preserved immediately upon collection as follows: pw.THg and pw.MeHg with 6 moles per liter (M) hydrochloric acid (1 percent final concentration), ferrous iron (pw.Fe(II)) with 10 percent hydrochloric acid (2 percent final concentration), pw.DOC with phosphoric acid to a $\mathrm{pH}$ less than 2 , and porewater sulfate $\left(\mathrm{pw} . \mathrm{SO}_{4}\right)$ was frozen.

\section{Streambed-Sediment Sampling}

Streambed-sediment samples were collected from undisturbed, continuously wetted, depositional zones in the stream channel that coincided with pore-water sampling locations (table 2-1). Samples collected during 2009 were composites of 5 to 10 representative subsamples over a 5 - to 10 -square meter $\left(\mathrm{m}^{2}\right)$ area of relatively homogeneous sediment
(Shelton and Capel, 1994). The upper 0- to 10-cm-depth interval of streambed sediment was sampled with a hand-held glass coring device, except at water depth greater than 1 meter (m) where an Eckman dredge was used. Samples collected for $\mathrm{THg}$ and $\mathrm{MeHg}$ were frozen onsite, whereas all other sediment samples were kept chilled on wet ice.

Streambed-sediment samples were collected during 2010 from one or two sediment cores ( 0 - to $10-\mathrm{cm}$ depth) per site as described in Lutz and others (2008). To better document spatial variability, both on a small scale around each site as well as on a larger scale between stream reaches, two to three primary sites per reach were sampled (for a total of 15 primary sites), plus three additional field replicate sediment samples collected within 10 to $50 \mathrm{~m}$ from each primary site (for a total of 45 field replicate sites; table 2-1). For each sampling location (primary and field replicate; total of 60 sampling sites), sediment was composited in a ziplock bag and kept cold and dark on wet ice in a cooler until further processed and subsampled (within 8 hours of sample collection). Sediment sample processing included homogenizing, subsampling, and preserving as appropriate for each analyte. Sediment ORP and $\mathrm{pH}$ were measured by standard electrochemical probe techniques (Marvin-DiPasquale and Agee, 2003). Incubations associated with benthic MPP rates were initiated within 8 hours of sample collection, as described below. Subsamples collected for organic content (as percent loss on ignition (percent LOI)), grain size less than $63 \mu \mathrm{m}$ (percent fines), porosity, dry weight, and bulk density were stored chilled on wet ice. All other subsamples were frozen.

\section{Toxicity Tests}

Surface-water and pore-water toxicity tests were conducted by the USEPA Region 1 ESAT of North Chelmsford, Massachusetts. Surface water (10-12 liters (L)) was collected for chronic, 7-day bioassays with larval fathead minnow (Pimephales promelas) and the cladoceran (Ceriodaphnia dubia) using survival, growth, and reproductive criteria (U.S. Environmental Protection Agency, 2008a, b). At least $1 \mathrm{~L}$ of pore water was collected at each site, which was used for acute, 96-hour survival bioassays conducted using the freshwater amphipod (Hyalella Azteca) and the larval midge (Chironomus tentans), as described by the U.S. Environmental Protection Agency (2001a). Detailed methods of pore-water and surface-water toxicity testing are described by Environmental Services Assistance Team (2009a, 2009b, respectively). Whole-sediment toxicity tests were run by EnviroSystems, Inc., of Hampton, N.H. Sediment samples were collected at locations coincident with porewater samples and were used for bulk sediment toxicity tests with the Hyallela azteca (28-day exposure) and Chironomus dilutus (20-day exposure) using survival- and growth-based criteria as described by EnviroSystems, Inc., (2010a, 2010b, respectively). All surface-water, pore-water, and bulksediment samples collected for toxicity tests were kept chilled on wet ice or refrigerated until use in the above bioassays. 


\section{Epifaunal Invertebrate Assemblages}

Epifaunal invertebrate samples were collected following NHDES benthic index of biotic integrity (B-IBI) protocols (New Hampshire Department of Environmental Services, 2004). Rock baskets $(16.5 \mathrm{~cm} \times 28 \mathrm{~cm})$ containing 3.8 - to 7.6-cm-diameter gravel were placed in riffle habitats upstream from water-chemistry sampling sites at water depths deep enough to maintain continuous flow over the artificial substrate. Four baskets per site were anchored to the streambed by sections of steel reinforcing rod (rebar) that were approximately $1.2 \mathrm{~m}$ long and 19 millimeters $(\mathrm{mm})$ in diameter. Invertebrate samples collected from three of the four rock baskets were used to evaluate the aquatic ecosystem health, which is based on the presence of certain taxa and the abundance of organisms at the sampling sites. The organisms collected from the fourth rock basket at each site were combined in a single sample that was analyzed for THg. The rock baskets were deployed August 6-7, 2009, and retrieved 6.5 weeks later (September 21-22, 2009).

Rock baskets were retrieved by placing a 500-mesh D-frame net downstream from the rock basket and gently lifting and sliding the rock basket into the net. Rock baskets were emptied into 500- $\mu \mathrm{m}$ sieve buckets. The empty basket cages were gently scrubbed and rinsed into 5-gallon pails, and the contents were poured into the sieve bucket. Rocks in the sieve buckets were gently brushed and rinsed to remove organisms and detritus and returned to basket cage. Leaves and detritus in the sieve bucket were rinsed, inspected for organisms, and returned to the stream. The contents of the sieve bucket were transferred to jars and preserved with 70-percent ethanol. Samples for tissue chemistry were thoroughly rinsed with site water, placed in glass jars, and frozen for subsequent analysis of THg using a Milestone direct mercury analyzer (DMA) at the USEPA laboratory in Chelmsford, Mass. Invertebrate assemblage samples were processed according to NHDES B-IBI protocols (New Hampshire Department of Environmental Services, 2004) with a 300-organism count and identified to genus and species level by Lotic, Inc., of Unity, Maine.

\section{Infaunal Invertebrate Tissue}

Infaunal worms (Oligochaeta spp.) were collected from the top $15 \mathrm{~cm}$ of sediment in the same locations as the porewater and sediment samples. A minimum of 5 grams (g) of infaunal worms were washed of external sediment and debris, placed in glass jars, and frozen. Tissue samples were analyzed for THg using a DMA at the U.S. Department of Energy National Renewable Energy Laboratory in North Chelmsford (Nobis Engineering, 2009).

\section{White Sucker, Smallmouth Bass, and Crayfish}

Fish samples were collected by Avatar Environmental using electroshocking during August 2009 and by the U.S. Fish and Wildlife Service, the USEPA, and ESAT using rod and reel and gill nets during August 2011 (Nobis Engineering, 2009). Two whole-body composite samples of white sucker (Catostomus commersoni) were collected at three stream reaches during 2009 (table 1). Composite white sucker samples consisted of two to five fish. During 2011, individual whole-body samples of white sucker were collected at four stream reaches. Smallmouth bass (Micropterus dolomieui) of $25-$ to $38-\mathrm{cm}$ length were collected in 2009 and greater than $25-\mathrm{cm}$ length during 2011. Smallmouth bass samples were five individual skinless fillets of at least $5 \mathrm{~g}$. All fish samples were rinsed with deionized water, wrapped in plastic wrap, placed in ziplock bags, and frozen. Crayfish were collected by trapping or electroshocking. Two composites of 5 to 10 whole crayfish (more than $100 \mathrm{~g}$ wet weight) were collected at each site during August 2009, and 10 individual whole crayfish were collected at each site during August 2011 (Nobis Engineering, 2009). Crayfish were rinsed with deionized water, placed in a ziploc bag, and immediately chilled on wet ice.

\section{Bats and Birds}

Blood and fur from little brown bats (Myotis lucifugus) and big brown bats (Eptesicus fuscus) were sampled by BioDiversity Research Institute at the AR1 reference site (Pontook Reservoir) and downstream at AR9. Bats were collected using mist nets as described by Buck and Evers (2011). Tree swallows (Tachycineta bicolor) were sampled by ESAT at the two reference locations (Pontook Reservoir (AR1) and Wheeler Bay (AR2)) and four downstream stream reaches (AR3, AR4, AR8, and AR9). Blood, eggs, and feathers of adult and nestling tree swallows were collected as described in the Ecological Investigation Quality Assurance Project plan (Nobis Engineering, 2011).

\section{Laboratory Methods}

The laboratory methods detailed below were conducted by the USGS Branch of Regional Research, Western Region (USGS BRR-WR) Laboratory in Menlo Park, California, and were associated with the streambed-sediment and pore-water samples collected during 2010 only. These methods reflect the key parameters discussed in detail in this report. These and all other laboratory methods are summarized in table 2 (in back of report). 


\section{Total Mercury}

THg analysis was conducted on all 60 streambedsediment samples collected during 2010. Samples were stored frozen until analysis. After thawing, sediment THg was first extracted overnight in concentrated acid (aqua regia; concentrated nitric acid $\left(\mathrm{HNO}_{3}\right)$ plus hydrochloric acid $(\mathrm{HCl})$ at a 1:3 ratio), followed by the addition of the oxidant bromine monochloride $(\mathrm{BrCl})$ and heating overnight at 60 degrees Celsius $\left({ }^{\circ} \mathrm{C}\right)$ to ensure all the mercury was in the divalent inorganic form $(\mathrm{Hg}(\mathrm{II}))$ in accordance with standard USGS protocol (Olund and others, 2004). THg in the extract was assayed by cold vapor atomic fluorescence spectrometry (CVAFS) using a Tekran 2006 automated total mercury analyzer in accordance with USEPA method 1631 (U.S. Environmental Protection Agency, 2001b, 2002). Further details on the method are described in Marvin-DiPasquale and others (2011). Each batch of analytical samples was accompanied by the analysis of the following minimum number of quality assurance (QA) samples: one certified reference material, one matrix spike, one analytical duplicate, one field duplicate, one method blank, and calibration standards prepared from commercially certified mercuric chloride $\left(\mathrm{HgCl}_{2}\right)$ solution.

Pore-water samples collected for pw.THg analysis were preserved in the field with a final concentration of 0.5 -percent $\mathrm{HCl}$ and stored refrigerated in the dark until further processing. Subsequently, the samples were initially oxidized with $\mathrm{BrCl}$ and similarly analyzed by CVAFS using a Tekran 2600 automated total mercury analyzer in accordance with USEPA method (U.S. Environmental Protection Agency, 2001b, 2002). Each batch of analytical samples was accompanied by the analysis of the following minimum number of QA samples: one matrix spike, one analytical duplicate, one field duplicate, one method blank, and calibration standards prepared from commercially certified $\mathrm{HgCl}_{2}$ solution. For sediment and pore water, the detection limit for the THg assay is approximately 0.5 nanogram per liter (ng/L) at the level of the autoanalyzer. QA results for sediment and pore-water THg assays are detailed in appendix 1 .

\section{Methylmercury}

$\mathrm{MeHg}$ analysis was conducted on the 15 primary streambed-sediment samples collected during 2010. Samples were stored frozen until analysis. After thawing, sediment $\mathrm{MeHg}$ was first extracted with a solution of 25-percent potassium hydroxide (KOH) in methanol at $60^{\circ} \mathrm{C}$ for 4 hours (Xianchao and others, 2005). Quantification of $\mathrm{MeHg}$ in the extract was then carried out after ethylation of the analyte using a Brooks Rand Labs automated MeHg analyzer (MERX). Further method details are described in Marvin-DiPasquale and others (2011). Each batch of analytical samples was accompanied by the analysis of the following minimum number of QA samples: one certified reference material, one matrix spike, one analytical duplicate, one field duplicate, one method blank, and calibration standards prepared from commercial crystalline methylmercury chloride $(\mathrm{MeHgCl})$ and compared with a separate, commercially available $\mathrm{MeHg}$ standard solution.

Pore-water samples collected for pw.MeHg analysis were preserved in the field with a final concentration of 0.5 percent $\mathrm{HCl}$ and stored refrigerated in the dark until further processing. Subsequently samples were distilled (U.S. Environmental Protection Agency, 2001b) and then quantified after ethylation of the analyte using a MERX (MarvinDiPasquale and others, 2011). The detection limit for the $\mathrm{MeHg}$ assay is approximately 0.5 picogram (pg; absolute mass as mercury). QA results for sediment and pore-water $\mathrm{MeHg}$ assays are detailed in appendix 1.

\section{Reactive Inorganic Mercury}

$\mathrm{Hg}(\mathrm{II})_{\mathrm{R}}$ analysis was conducted on all 60 streambedsediment samples collected during 2010. Sediment $\mathrm{Hg}(\mathrm{II})_{\mathrm{R}}$ is methodologically defined as the fraction of total $\mathrm{Hg}$ (II) that is readily reduced to $\mathrm{Hg}^{0}$ by an excess of tin chloride $\left(\mathrm{SnCl}_{2}\right)$ over an exposure time of 15 minutes. Further method details are described in Marvin-DiPasquale and Cox (2007). Sediment subsamples for $\mathrm{Hg}(\mathrm{II})_{\mathrm{R}}$ were stored frozen until analysis. Each batch of analytical samples was accompanied by the analysis of the following minimum number of QA samples: one analytical duplicate, one field duplicate, four bubbler blanks, and calibration standards prepared from a commercial $\mathrm{HgCl}_{2}$ stock solution. No commercially available certified reference material exists for $\mathrm{Hg}(\mathrm{II})_{\mathrm{R}}$ in sediment. The detection limit for the $\mathrm{Hg}(\mathrm{II})_{\mathrm{R}}$ assay is approximately $40 \mathrm{pg}$ (absolute mass). QA results are detailed in appendix 1.

\section{Methylmercury Production Potential and Microbial Divalent-Mercury-Methylation Rate Constant}

MPP rates were assessed for the 15 primary streambedsediment samples collected during 2010. Bulk sediment MPP rates were quantified using a stable isotope incubation approach (Marvin-DiPasquale and others, 2011). Incubations were initiated 4 to 8 days after initial field collection of the sediment. Three subsamples of sediment ( $3.0 \mathrm{~g}$ wet weight) per site were transferred into 13-cubic centimeter $\left(\mathrm{cm}^{3}\right)$ sealed serum vials under anaerobic conditions (nitrogen gas $\left(\mathrm{N}_{2}\right)$-flushed glove bag). An isotopically enriched solution $(0.1$ milliliter $(\mathrm{mL}))$ of mercury chloride $\left({ }^{200} \mathrm{HgCl}_{2}\right)$ was then injected through the sepum of each vial for a final amendment concentration of 38 nanograms (ng) of isotopic mercury $\left({ }^{200} \mathrm{Hg}(\mathrm{II})\right)$ per gram of sediment (wet weight). The samples were vortexed for 1 minute each immediately following the isotope amendment. One sample per set was immediately flash frozen in a bath of dry ice and ethanol. This sample represented the killed control. The remaining two samples per set were incubated at $20^{\circ} \mathrm{C}$ for 5 hours, after which they too 
were flash frozen in dry ice and ethanol and stored at $-80^{\circ} \mathrm{C}$ until further processing, which consisted of extraction with 25-percent $\mathrm{KOH}$ in methanol and quantification by isotopedilution inductively coupled plasma mass spectrometry (ICPMS; Marvin-DiPasquale and others, 2011).

Pseudo-first-order rate constants for ${ }^{200} \mathrm{Hg}$ (II)-methylation $\left(\mathrm{k}_{\text {meth }}\right.$, units $=1 /$ done per day $)$ were then calculated from the incubated samples as described for the radiotracer ${ }^{203} \mathrm{Hg}$ (II)methylation assay in Marvin-DiPasquale and others (2008).

Daily MPP rates (in ng/g dry sediment per day) were calculated as:

$$
\mathrm{MPP}=\mathrm{Hg}(\mathrm{II})_{\mathrm{R}}-\left(\mathrm{Hg}(\mathrm{II})_{\mathrm{R}} \times \exp \left(-\mathrm{k}_{\text {meth }} \times t\right)\right),
$$

where

$t \quad$ is the time during which methylation occurred (for the purposes of this rate, 1 day); and

$\mathrm{Hg}(\mathrm{II})_{\mathrm{R}} \quad$ is the independently measured in-situ concentration of inorganic reactive mercury, in ng/g dry weight.

QA consisted of killed controls, analytical duplicates for every site, and the use of internal standards (that is, isotopically enriched $\left.\mathrm{MeHg}\left(\mathrm{Me}^{199} \mathrm{Hg}\right)\right)$.

\section{Mercury Sequential Extraction}

$\mathrm{THg}$ sequential extraction analysis was conducted on the 15 primary streambed-sediment samples collected during 2010. Sediment sequential extraction followed the fivefraction (F1 thru F5) scheme detailed in Bloom and others (2003) and Marvin-DiPasquale and others (2011) with each successive fraction using a stronger extraction solution (from deionized water to aqua regia) to dissolve mercury in the sediment sample. The specific extraction solutions and typical mercury species extracted with them are detailed in table 3 . The starting sample mass extracted was $3 \pm 0.2 \mathrm{~g}$ wet weight with the exact weight $( \pm 0.001 \mathrm{~g})$ noted. Each extraction step was conducted overnight for a minimum of 12 hours. The analysis of THg on each extraction fraction was conducted as described above for pore water. For QA, 3 of the 15 samples were run in duplicate, as were reagent blanks for all extractants. The relative percent difference (mean plus or minus standard error) for analytical duplicates associated with the five fractions were as follows (number of samples in each case equals three): $\mathrm{F} 1=21 \pm 16$ percent, $\mathrm{F} 2=30 \pm 6$ percent, $\mathrm{F} 3=$ $7.5 \pm 3.9$ percent, $\mathrm{F} 4=22 \pm 14$ percent, and $\mathrm{F} 5=9.6 \pm 5.3$ percent. No certified reference material is commercially available for these method-defined sequential extraction fractions.

\section{Iron Speciation}

Iron speciation analysis was conducted on the 15 primary streambed-sediment samples collected during 2010. Samples were stored frozen until analysis. Three forms of sediment iron were assayed: acid-extractable ferrous iron (Fe(II) $)_{\mathrm{AE}}$, amorphous (poorly crystalline) ferric iron ( $\mathrm{Fe}(\mathrm{III})_{\mathrm{a}}$ ), and crystalline ferric iron $\left(\mathrm{Fe}(\mathrm{III})_{\mathrm{c}}\right)$. Method details are described in Marvin-DiPasquale and others (2008). The typical detection limit for each iron fraction is approximately 0.01 milligram per milliliter $(\mathrm{mg} / \mathrm{mL})$ at the level of the spectrophotometric analysis. Each batch of analytical samples was accompanied by the analysis of the following minimum number of QA samples: one analytical duplicate, one field duplicate, one matrix spike for $\mathrm{Fe}(\mathrm{II})_{\mathrm{AE}}$ and $\mathrm{Fe}(\mathrm{III})_{\mathrm{c}}$ fractions only, one method blank, and ferrous sulfate $\left(\mathrm{FeSO}_{4}\right)$ calibration standards prepared from analytical-grade crystalline reagents. No certified reference material is commercially available for these method-defined iron species. QA results are detailed in appendix 1.

\section{Total Reduced Sulfur}

Total reduced sulfur (TRS) analysis was conducted on the 15 primary streambed-sediment samples collected during 2010. Samples were stored frozen until analysis. After

Table 3. Sequential extraction scheme applied to surface sediment samples from the Androscoggin River, Coos County, New Hampshire.

[The mercury sequential extraction sequence (Bloom and others, 2003) with each fraction number (F\#) is described by the extraction solution used and the dominant mercury species associated with that fraction. $\mathrm{DI}$, deionized; $\mathrm{Hg}$, mercury; $\mathrm{HgCl}_{2}$, mercuric chloride; $\mathrm{HgSO}_{4}$, mercuric sulfate; $\mathrm{M}$, moles per liter; $\mathrm{HCl}$, hydrochloric acid; $\mathrm{HgO}$, mercuric oxide; $\mathrm{KOH}$, potassium hydroxide; $\mathrm{Hg}(\mathrm{II})$, inorganic divalent mercury; $\mathrm{MeHg}$, methylmercury; $\mathrm{Hg}_{2} \mathrm{Cl}_{2}$, mercurous chloride; $\mathrm{HNO}_{3}$, nitric acid; $\mathrm{Hg}^{0}$, elemental mercury; $\mathrm{HgS}$, cinnabar; $\mathrm{m}-\mathrm{HgS}$, metacinnabar; $\mathrm{HgAu}$, mercury gold amalgam]

\begin{tabular}{lll}
\hline F\# & \multicolumn{1}{c}{ Extraction } & \multicolumn{1}{c}{ Dominant mercury species } \\
\hline F1 & DI water & Soluble, $\mathrm{HgCl}_{2}, \mathrm{HgSO}_{4}$ \\
F2 & $\mathrm{pH}=2 ; 0.1 \mathrm{M}$ acetic acid plus $0.01 \mathrm{M} \mathrm{HCl}$ & $\mathrm{HgO}, \mathrm{HgSO}_{4}$ \\
F3 & $1 \mathrm{M} \mathrm{KOH}$ & Organic or particle bound $\mathrm{Hg}(\mathrm{II}), \mathrm{MeHg}_{2} \mathrm{Hg}_{2} \mathrm{Cl}{ }_{2}$ \\
F4 & $12 \mathrm{M} \mathrm{HNO}_{3}$ & Elemental $\mathrm{Hg}^{0}, \mathrm{Hg}_{2} \mathrm{Cl}_{2}$ \\
F5 & Aqua regia (concentrated $\mathrm{HNO}_{3}$ and $\mathrm{HCl}$ at $1: 3$ ratio) & $\mathrm{HgS}, \mathrm{m}-\mathrm{HgS}, \mathrm{HgAu}$ \\
\hline
\end{tabular}


thawing, sediment TRS was extracted by a single-step hot acid chromium reduction approach and quantified spectrophotometrically (Marvin-DiPasquale and others, 2008). Each batch of analytical samples was accompanied by the analysis of the following minimum number of QA samples: one analytical duplicate, one field duplicate, one method blank, and zinc sulfide ( $\mathrm{ZnS}$ ) calibration standards. No certified reference material is commercially available for the TRS assay. The detection limit for this assay is approximately 0.2 micromole per milliliter $(\mu \mathrm{mol} / \mathrm{mL})$ at the level of the spectrophotometric analysis. QA results are detailed in appendix 1.

\section{Grain Size}

Grain-size analysis was conducted on all 60 streambedsediment samples collected during 2010. Samples were stored refrigerated until analysis. Sediment percent fines was assayed as the weight percentage of dry sediment less than 63 micrometers (less than $63 \mu \mathrm{m}$, the sand/silt split) and was conducted by wet sieving (Matthes and others, 1992). Each batch of analytical samples was accompanied by the analysis of the following minimum number of QA samples: one analytical duplicate and onefield duplicate. No certified reference material is commercially available for the grain size analysis. QA results are detailed in appendix 1.

\section{Dry Weight, Bulk Density, Porosity, and Organic Content}

Analysis of bulk density, dry weight, porosity, and organic content (as percent LOI) was conducted on all 60 streambed-sediment samples collected during 2010. Samples were stored refrigerated until analysis. These four sediment parameters were analyzed consecutively from single sediment subsamples, as previously detailed (MarvinDiPasquale and others, 2008). Each batch of analytical samples was accompanied by the analysis of the following minimum number of QA samples: one analytical duplicate at all sites and one field duplicate. No certified reference material is commercially available for this suite of sediment analyses. QA results are detailed in appendix 1 (table 1-3).

\section{Total and Organic Carbon, Total Nitrogen, and Carbon and Nitrogen Isotopes}

Analysis of total carbon (TC), total organic carbon (TOC), and total nitrogen (TN), with associated isotopes $\left(\delta^{13} \mathrm{C}\right.$ and $\delta^{15} \mathrm{~N}$, respectively), was conducted on all 60 streambedsediment samples collected during 2010. Samples were stored frozen until analysis. Analysis was conducted as described in Kendall and others (2001) using a Carlo Erba model 1500 elemental analyzer connected to an Elementar Isoprime mass spectrometer before and after acidification ( $\mathrm{HCl}$ acid fuming overnight to remove inorganic carbon). Each batch of analytical samples was accompanied by the analysis of the following minimum number of QA samples: one analytical duplicate, one field duplicate, and calibration standards prepared from ethylene-diamine-tetra-acetic acid. QA results for $\mathrm{TC}$ and $\mathrm{TN}$ are detailed in appendix 1.

\section{Pore-Water Dissolved Organic Carbon}

Analysis of pw.DOC was conducted on pore water collected from the 15 primary streambed sites sampled during 2010. Samples were stored refrigerated and acidified (to a $\mathrm{pH}$ of less than 2) until analysis. Analysis for pw.DOC was conducted using high temperature combustion and infrared (IR) detection on a Shimadzu Scientific Instruments TOCVCPH total organic carbon analyzer. QA measures included analytical duplicates, field duplicates, calibration standards, method blanks, and reagent blanks. QA results are detailed in appendix 1 .

\section{Pore-Water Sulfate and Chloride}

Analysis of pw. $\mathrm{SO}_{4}$ and pore-water chloride (pw.Cl) was conducted on pore water collected from the 15 primary streambed sites sampled during 2010. Samples were stored frozen until analysis and assayed by ion chromatography as described in Marvin-DiPasquale and others (2008). QA measures included analytical duplicates, field duplicates, calibration standards, method blanks, and reagent blanks. QA results are detailed in appendix 1.

\section{Pore-Water Ferrous Iron}

Analysis of pw.Fe(II) was conducted on pore water collected from the 15 primary streambed sites sampled during 2010. Samples were stored refrigerated and acidified (to a $\mathrm{pH}$ of less than 2) until analysis and assayed by the colorimetric ferrozine assay as described in Marvin-DiPasquale and others (2008). QA measures included analytical duplicates, field duplicates, calibration standards, method blanks, and reagent blanks. QA results are detailed in appendix 1.

\section{Data Analysis}

Statistical analysis was performed using the TICBO Sptofire S+, version 8.1 software. Type II error probability (p) was set at less than 0.05 for all statistical tests, unless otherwise noted. We generally report median and interquartile range (IQR) data throughout the Results and Discussion section because the two-sided Kolmogorov-Smirnov goodnessof-fit test indicated that a majority (more than 60 percent) of the parameters measured in this study were not normally distributed. For data below the reporting limit, medians and IQRs were calculated using maximum likelihood estimation (Helsel, 2005) subroutines developed by the USGS for the 
$\mathrm{S}+$ statistical platform. The mercury distribution in sediment, pore water, and biota was analyzed by comparing grouped medians from samples collected downstream from the former chloralkali facility to the reference sites using the nonparametric Wilcoxon rank sum (WRS) test. Downstream stream reaches were split into two spatial groupings determined by stream gradient: near-stream reaches (AR3 (fish only), AR4, AR5, and AR6), 0 to $4 \mathrm{~km}$ downstream from the point source in an area of steep stream gradients, and far-stream reaches (AR7, AR8, and AR9), 8 to $16 \mathrm{~km}$ downstream from the point source where stream gradients were much more gradual (fig. 1). Grouped medians of samples collected from reference, near, and far-stream reaches were compared using the nonparametric Kruskal-Wallis rank sum (KWRS) test. If KWRS indicated a significant difference between groupings, Tukey multiple-comparison test was used to determine which medians differed significantly.

Starting with multiple (four to seven) explanatory variables, best-fit linear model equations were developed using step-wise linear regression to describe the spatial variability in key mercury metrics. Prior to model development, parameters that were not normally distributed were $\log$-base $10\left(\log _{10}\right)$ transformed and used in the model. Explanatory variables (independent or $x$ variables) with type II error $\mathrm{p}$ more than 0.1 were removed from the regression equations; all overall model fits required $\mathrm{p}$ less than 0.05 as a testing criterion.

\section{Results and Discussion}

Samples from various matrices were collected to (1) define areas of mercury contamination, (2) better understand factors controlling $\mathrm{MeHg}$ production and bioaccumulation, and (3) assess the ecological impact of the mercury contamination. Tabular results of all physical parameters measured and chemical analysis conducted on surface water, pore water, sediment, invertebrates, fish, bats, and birds are listed in tables A2-2 through 2-22. Sediment and pore-water analyses included in this report are only of depositional areas, not the entire stream channel. The results from the statistical (nonparametric WRS) assessment of sediment, pore water, toxicity tests, and select biota data, comparing the reference reaches (AR1 and AR2) to all stream reaches downstream from the former chloralkali plant, are summarized in table 4 (in back of report).

The results from the statistical (nonparametric KWRS) assessment of sediment, pore water, toxicity tests, and select biota data, comparing the reference reach (AR2) with near downstream stream reaches (AR3, AR4, AR5, and AR6) and with far downstream stream reaches (AR7, AR8, and AR9), are summarized in table 5 (in back of report). Ancillary parameters that showed no significant differences among the spatial groupings were not included in tables 4 or 5 (in back of report); these parameters included sediment TC, TN, carbon to nitrogen ratio $(\mathrm{C}: \mathrm{N}), \mathrm{TOC}$, percent LOI, TRS, $\mathrm{Fe}(\mathrm{II})_{\mathrm{AE}}$,
$\mathrm{Fe}(\mathrm{III})_{\mathrm{a}}, \mathrm{Fe}(\mathrm{III})$, carbon $13\left({ }^{13} \mathrm{C}\right)$ and nitrogen $15\left({ }^{15} \mathrm{~N}\right)$ isotopes, and pore-water parameters pw.Fe(II), pw. $\mathrm{SO}_{4}$, and pw.DOC. The lack of significant spatial differences generally reflected the limited range of parameter concentrations in the study area.

\section{Mercury Speciation and Distribution}

THg and $\mathrm{MeHg}$ concentrations in surface water, sediment, pore water, and biota were compared downstream from the former chloralkali facility relative to reference sites. Sequential extraction of surface sediment was used to assess differences in mercury speciation upstream and downstream from the facility.

\section{Surface Water}

The number (n) of observations associated with the 2009 surface-water samples was too small $(\mathrm{n}=5)$ for statistical evaluation of the spatial groupings used for sediment. However, visual inspection of the data (table 2-2) showed little difference among the various stream reaches sampled for filtered THg (range from 0.70 to $1.00 \mathrm{ng} / \mathrm{L}$, mean of $0.87 \mathrm{ng} / \mathrm{L}$ ), nonfiltered $\mathrm{THg}$ (range from 0.44 to $2.17 \mathrm{ng} / \mathrm{L}$, mean of $1.13 \mathrm{ng} / \mathrm{L}$ ), filtered MeHg (all less than $0.1 \mathrm{ng} / \mathrm{L}$ ), nonfiltered $\mathrm{MeHg}$ (all less than $0.1 \mathrm{ng} / \mathrm{L}$ ), and $1 \mathrm{M} \mathrm{KOH}-$ extractable $\mathrm{Hg}$ (II) (all less than $0.08 \mathrm{ng} / \mathrm{L}$ ). This observed limited variability between surface-water samples collected around a point source in a high-gradient stream is not surprising because of the short hydrologic residence time.

\section{Sediment and Pore Water}

Sediment $\mathrm{THg}$ and $\mathrm{MeHg}$ concentrations were significantly higher downstream from the point source than at the reference site (table 4 , in back of report). The highest median sediment $\mathrm{THg}$ and $\mathrm{MeHg}$ concentrations were in stream reach AR5, $2.5 \mathrm{~km}$ downstream from the point source (figs. 3A and B). No significant difference existed between near- and far-stream reaches, suggesting that sediment $\mathrm{THg}$ and $\mathrm{MeHg}$ concentrations were not decreasing downstream from the point source as far as Shelburne Dam, and could possibly continue at elevated levels downstream from Shelburne Dam (table 5, in back of report).

Whereas pw.MeHg concentrations were significantly higher downstream from the point source than at the reference site, pw.THg concentrations were not (table 4, in back of report). The highest pw.THg and pw.MeHg concentrations were in stream reach AR4, $2 \mathrm{~km}$ downstream from the point source (figs. 4A and B). Samples from AR4 were collected in a depositional area in and around a dense stand of aquatic emergent vegetation. The median pw.DOC concentrations at this location were also three times higher than other stream reaches (fig. 5). The elevated pw.DOC concentrations at AR4 may facilitate the desorption of organic and inorganic mercury 

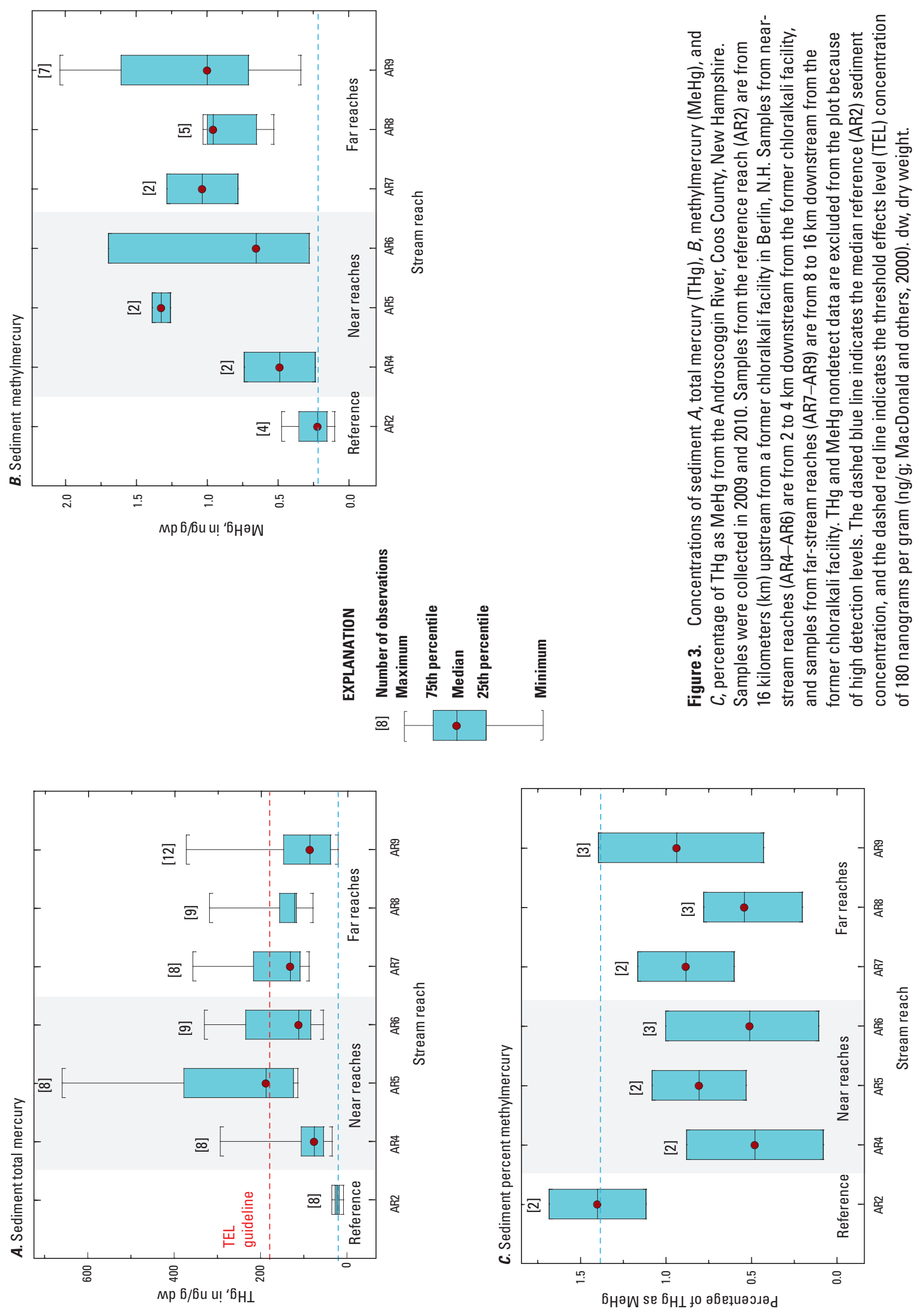

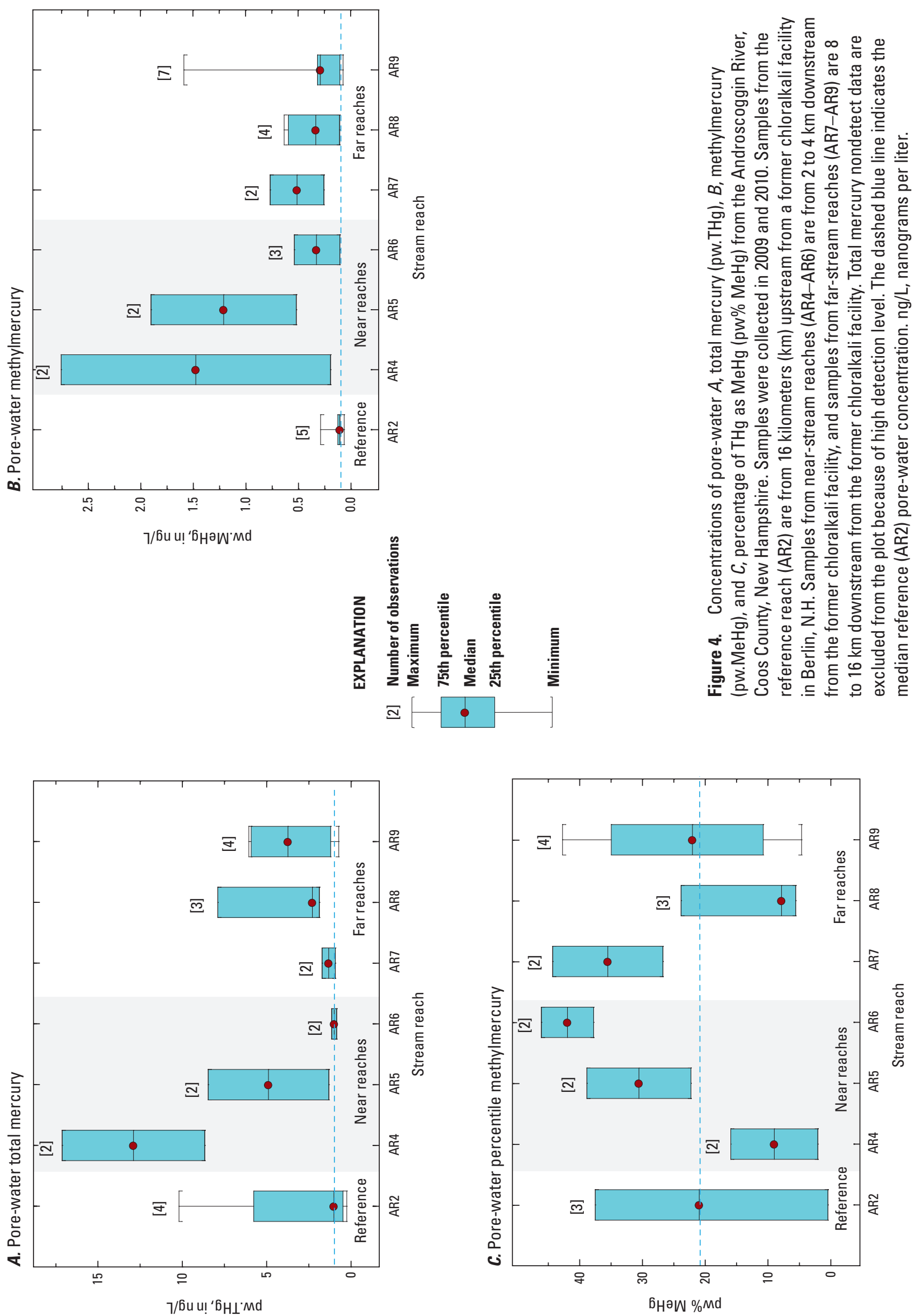

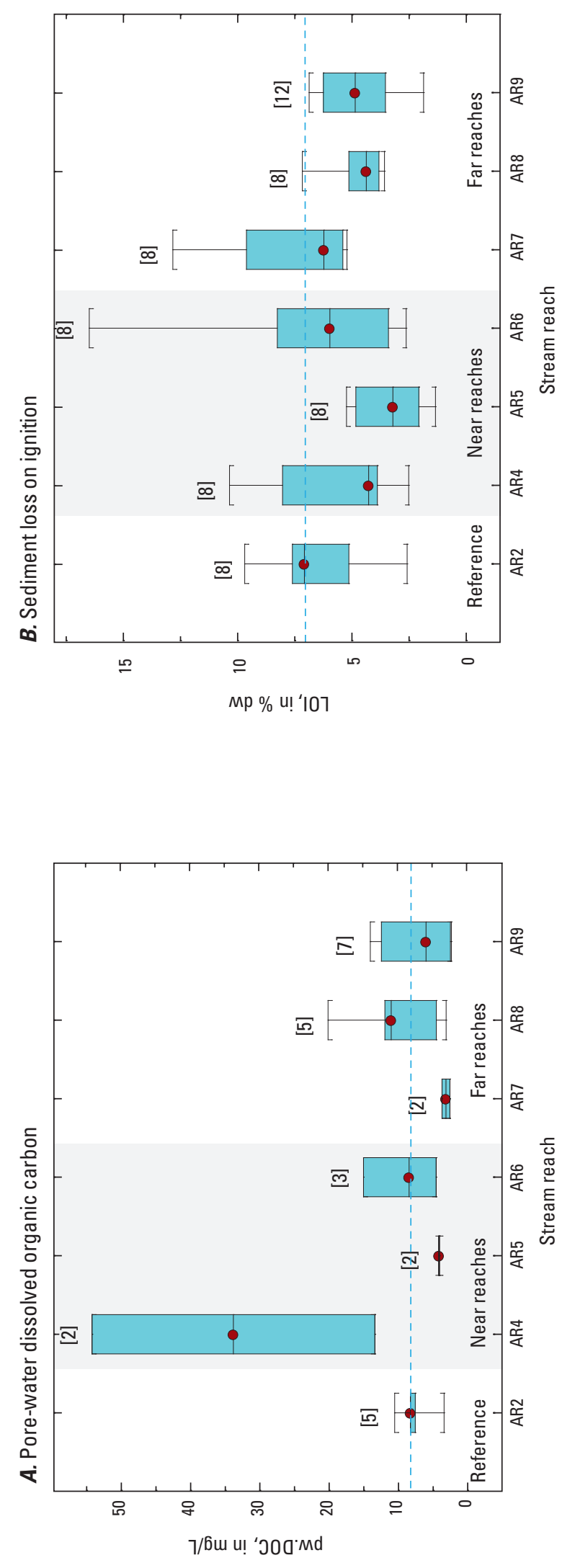

틈 듬

离 㪣

을

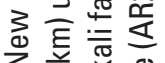

क क

릏흘 흔

仓े

果 을

ن은

过

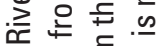

言离 동.

O즌

造这要

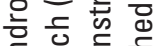

运芯密

잉

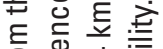

인

更迹

틀

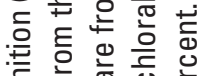

든 흔 등

ᄃ응후

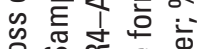

은 क

む엏ㅎㅎ

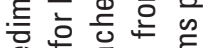

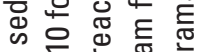

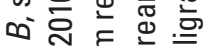

을 䎡壳

匹

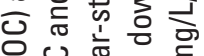

잉

文员志

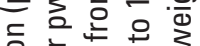

둥ㅎㅇ

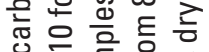

ง 들

กึ ฏ

完 品元

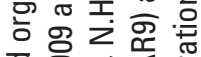

일.

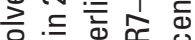

的客定

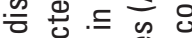

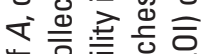

후웡

क 凹

응 要离

㝴

흔

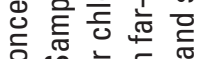

ठํ ॐ

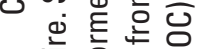

内

닌 을 능

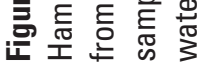


species off particles and into the pore water dissolved phase (Hill and others, 2009; Dong and others, 2010). The lower sediment partitioning coefficients $\left(\mathrm{K}_{\mathrm{d}}^{\mathrm{s}}\right)$ at AR4 confirmed that $\mathrm{THg}$ and $\mathrm{MeHg}$ partitioned into the dissolved phase to a greater extent in this particular reach compared with all other stream reaches (figs. 6A and $\mathrm{B}$ ).

The distribution of mercury species as identified in surficial-sediment sequential extractions was also significantly different between the reference site and downstream from the point source (tables 4,6 , in back of report). Concentrations of the three refractory fractions (F3, F4 and F5; table 3) were all significantly higher downstream from the point source, compared with the reference site. The highest concentration of $12 \mathrm{M} \mathrm{HNO}_{3}$-extractable mercury (F4 fraction typified by $\mathrm{Hg}^{0}$ or mercurous chloride $\left(\mathrm{Hg}_{2} \mathrm{Cl}_{2}\right)$ ) was found at $\mathrm{AR} 4$, the first reach downstream from the point source. At all sites, only a minor percentage (less than 0.1 percent) of THg existed in chemically labile forms (fractions F1 and F2; table 3). The relative composition of mercury species also changed downstream from the point source. The reference site had greater than 86 percent of $\mathrm{THg}$ in the $\mathrm{KOH}$ fraction, consistent with organic or particle bound $\mathrm{Hg}$ (II) (table 3 ), whereas downstream from the point source, the percentage of the F4 fraction increased dramatically (fig. 7). As much as 86 percent of the THg was found in this F4 fraction in stream reach AR4. No significant change in mercury species distribution was noted between near and far-stream reaches (table 5, in back of report), suggesting the elevated levels of refractory mercury species (potentially $\mathrm{Hg}^{0}$ or $\mathrm{Hg}_{2} \mathrm{Cl}_{2}$ ) continues at least as far as Shelburne Dam.

\section{Biota}

$\mathrm{THg}$ concentrations in smallmouth bass, white sucker, crayfish, oligochaetes, bat fur, nestling tree swallow blood and feathers, adult tree swallow blood, and tree swallow eggs were all significantly higher downstream from the point source than at the reference sites (table 4, in back of report). Far-stream reaches had significantly higher smallmouth bass and white sucker THg concentrations than near-stream reaches (fig. 8; table 5, in back of report). Median THg concentrations in bat blood and adult swallow feathers were higher downstream from the point source than the reference site, but the difference was not significant. The highest $\mathrm{THg}$ concentrations in epifaunal macroinvertebrates were found in the stream reach adjacent to the point source (AR3); however, the sample size $(n=5)$ was too small to conduct a statistical spatial comparison (table 2-16).

Smallmouth bass $\mathrm{THg}$ concentrations from this study were also compared with smallmouth bass fillet concentrations collected from the Androscoggin River between Rumford and Lisbon, Maine, (80-180 km downstream from the study area) by the Maine Department of Environmental Protection from 2000 to 2009 as part of the Surface Water Ambient Toxic Monitoring Program (Maine Department of Environmental Protection, 2009). Grouped medians from reference, near, far, and Maine stream reaches were compared using nonparameteric KWRS test. Smallmouth bass THg concentrations from Maine were significantly higher than the New Hampshire reference site in Wheeler Bay (AR2) and similar to far-stream reaches (AR7-AR9) between Gorham and Shelburne, suggesting elevated THg levels in smallmouth bass continue downstream from the study area (fig. 9).

\section{Mercury Bioavailability}

The potential for $\mathrm{Hg}$ (II)-methylation was evaluated using a number of different metrics including the percentage of $\mathrm{THg}$ as $\mathrm{MeHg}$ (percent $\mathrm{MeHg}$ ) in sediment, tin-reducible inorganic mercury $\left(\mathrm{Hg}(\mathrm{II})_{\mathrm{R}}\right)$, stable isotope ${ }^{200} \mathrm{Hg}$ (II)-methylation rate incubations to derive $\mathrm{k}_{\text {meth }}$, MPP rates calculated from independently measured $\mathrm{k}_{\text {meth }}$ and $\mathrm{Hg}(\mathrm{II})_{\mathrm{R}}$ data, and $\mathrm{THg}$ sequential extraction. Selective sequential extractions measured how readily mercury was leached from sediment; more readily leached organic bound mercury species are presumably more bioavailable for $\mathrm{Hg}$ (II)-methylation than the more refractory (strong acid soluble) compounds. All metrics indicated that mercury was relatively more available for $\mathrm{Hg}$ (II)-methylation at the reference site than downstream from the point source. The sediment percent $\mathrm{Hg}(\mathrm{II})_{\mathrm{R}}$ was significantly higher at the reference site than downstream from the point source (fig. 10B; table 4, in back of report). The median percent $\mathrm{MeHg}$ in sediment was highest at the reference site (fig. 3C); however, the difference was not significant, most likely due to the limited number of samples from the reference site (table 4, in back of report). Sequential extraction results indicated that a significantly higher percentage of $\mathrm{THg}$ was associated with the $\mathrm{F} 3$ fraction ( $\mathrm{KOH}$ soluble, indicative of organic or particle bound mercury) at the reference site, whereas sites downstream from the point source had a significantly higher percentage of refractory forms (F4 and F5 fractions; fig. 7; table 4, in back of report).

Although the proportion of mercury readily available for $\mathrm{Hg}(\mathrm{II})$-methylation appeared greater at the reference site compared with stream reaches downstream from the point source, the absolute concentration of $\mathrm{Hg}$ (II) readily available for $\mathrm{Hg}$ (II)-methylation and the extent of mercury bioaccumulation in biota was greater downstream from the point source. Sediment $\mathrm{Hg}(\mathrm{II})_{\mathrm{R}}$ concentrations were significantly higher downstream from the point source than at the reference site, as were $\mathrm{THg}$ concentrations in smallmouth bass, white sucker, crayfish, oligochaetes, bat fur, and swallow feathers, blood, and eggs (figs. 10A, 8A and B; table 4, in back of report). Sequential extractions of surficial sediment also indicated significantly higher concentrations of organic or particle bound mercury (F3 fraction) downstream from the point source compared with the reference site (table 4, in back of report). Median values for MPP and $\mathrm{k}_{\text {meth }}$ were also higher downstream from the point source compared with the reference site, but the difference was not significant most likely due to the small number of observations $(n=2)$ at the 

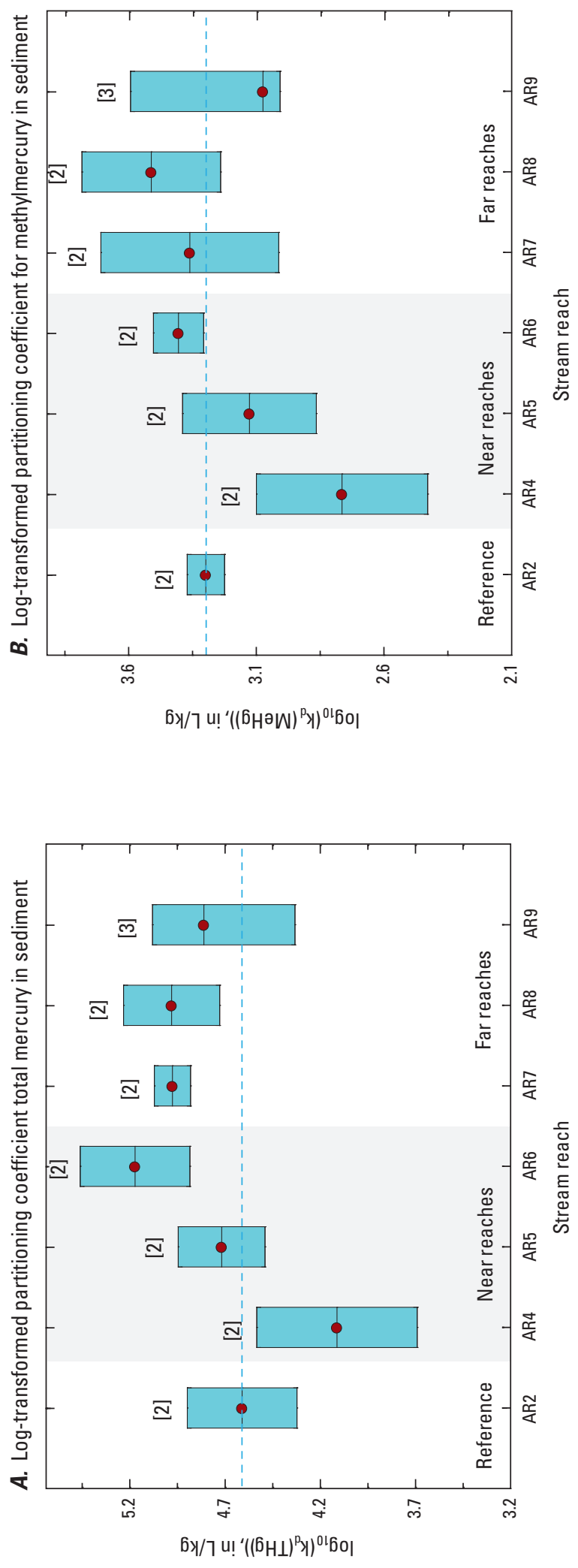

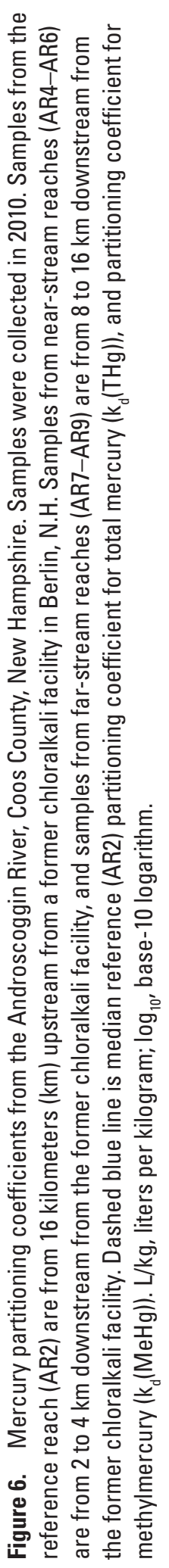




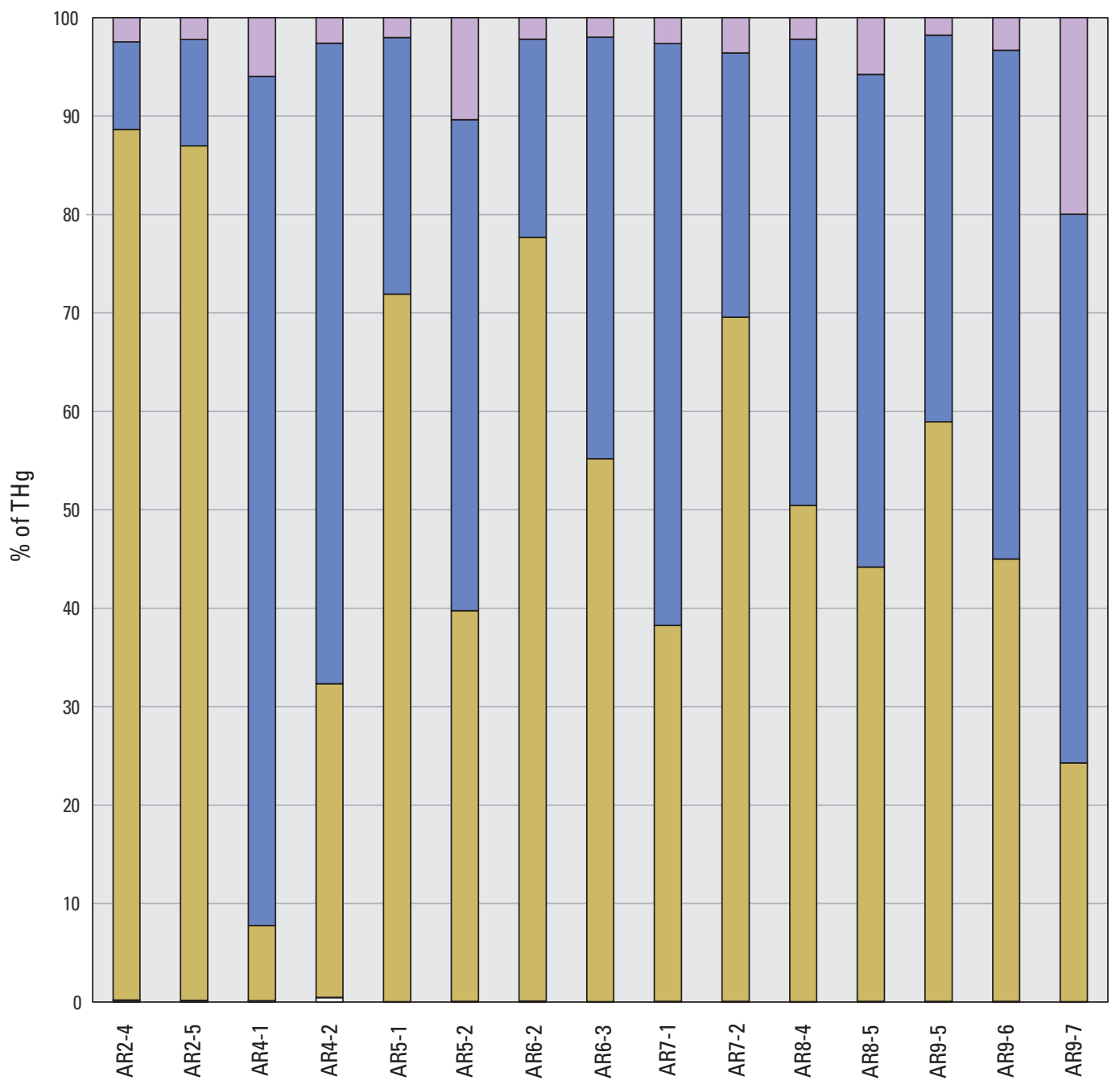

EXPLANATION

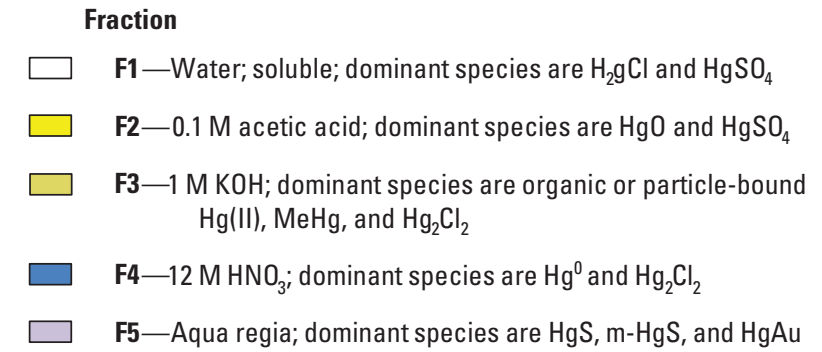

Figure 7. Sequential extractions of surficial sediment in the Androscoggin River, Coos County, New Hampshire. The mercury sequential extraction sequence (Bloom and others, 2003) shows each fraction number $(F \#)$ described by both the extraction solution used and the dominant mercury species associated with that fraction. AR, Androscoggin River, shows reach and site number (for example, AR2-4 is reach 2, site 4); $\mathrm{Hg}^{0}$, elemental mercury; $\mathrm{Hg}(\mathrm{II})$, divalent inorganic mercury; $\mathrm{HgAu}$, mercury and gold amalgam; $\mathrm{HgCl}_{2}$, mercuric chloride; $\mathrm{Hg}_{2} \mathrm{Cl}_{2}$, mercurous chloride; $\mathrm{HgO}$, mercuric oxide; $\mathrm{HgS}$, cinnabar; $\mathrm{HgSO}_{4^{\prime}}$ mercuric sulfate; $\mathrm{HNO}_{3^{\prime}}$ nitric acid; $\mathrm{KOH}$, potassium hydroxide; $\mathrm{M}$, moles per liter; $\mathrm{MeHg}$, methylmercury; $\mathrm{m}-\mathrm{HgS}$, metacinnabar; \% of THg, percentage of total mercury as fraction number (F\#). 

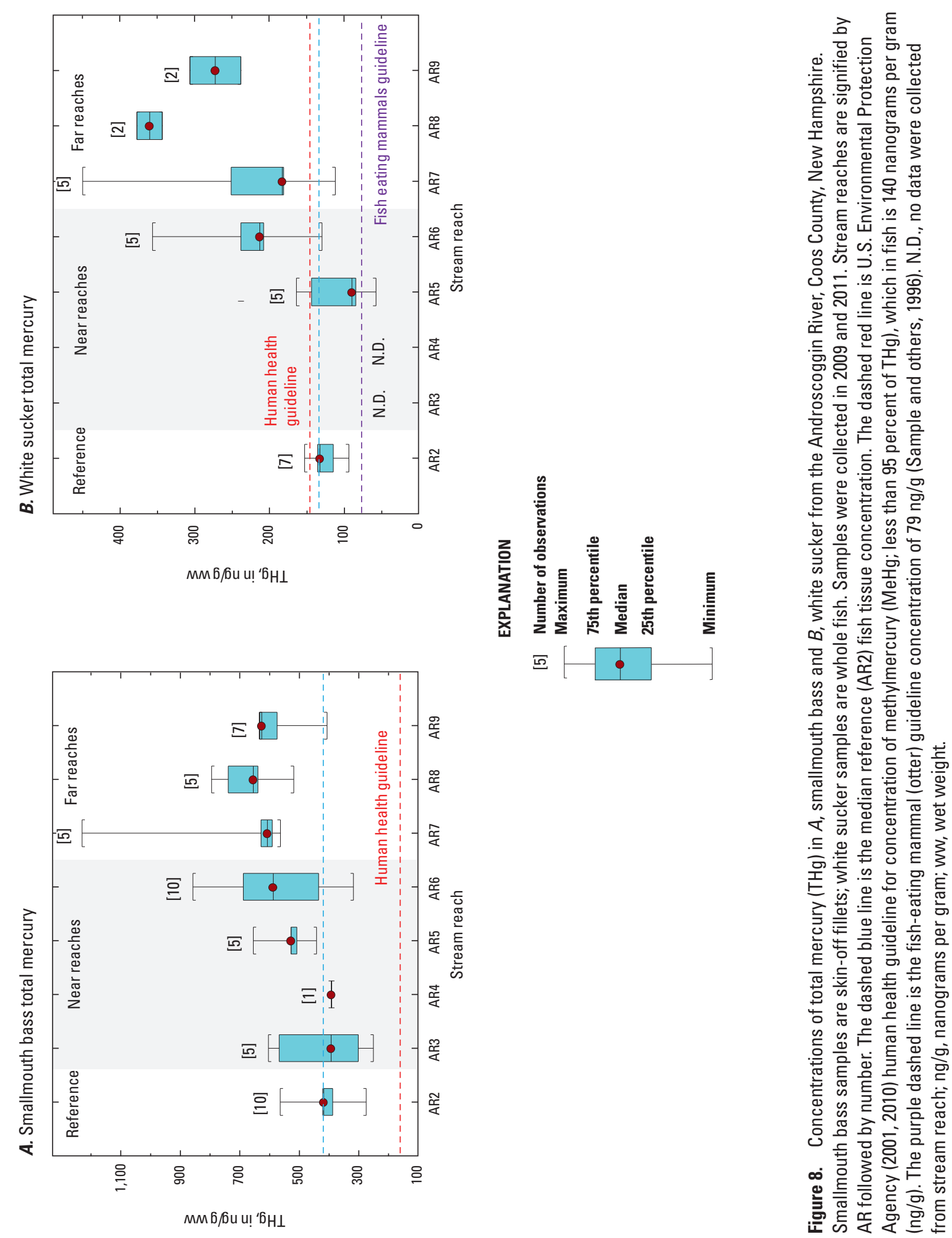


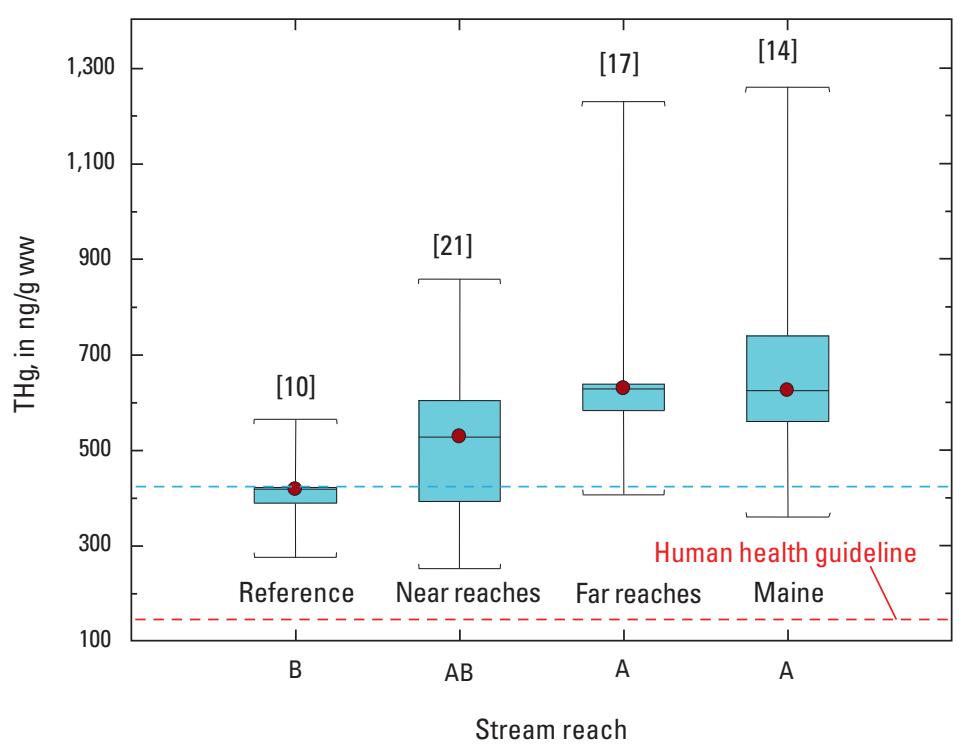

EXPLANATION

[10] Number of observations Maximum

75th percentile

Median

25th percentile

Minimum

Figure 9. Concentrations of total mercury (THg) in smallmouth bass from the Androscoggin River. The reference reach is 16 kilometers $(\mathrm{km})$ upstream from a former chloralkali facility in Berlin, N.H., near-stream reaches are 0 to $4 \mathrm{~km}$ downstream from the former chloralkali facility, far-stream reaches are 8 to $16 \mathrm{~km}$ downstream from the former chloralkali facility in Gorham and Shelburne, N.H., and the Maine sampling reach is 80 to $180 \mathrm{~km}$ downstream from the former chloralkali facility (Rumford to Lisbon, Maine). Data from Maine were collected by the Maine Department of Environmental Protection Surface Water Ambient Toxics Monitoring Program from 1990 through 2009. Data for New Hampshire were collected between 2009 and 2011. The dashed blue line is median reference (AR2) fish tissue concentration; red dashed line is the U.S. Environmental Protection Agency $(2001,2009)$ human health guideline. Letters A, B, and AB indicate statistical significance: Stream reaches labeled with " $A$ " are statistically different than stream reaches labeled with " $B$ ", and stream reaches labeled " $A B$ " are not statistically different than stream reaches labeled " $A$ " or " $B$." ng/g, nanograms per gram; ww, wet weight.

reference site (table 4 , in back of report). The highest values of $\mathrm{k}_{\text {meth }}$ were observed at AR4 (fig. 10C), an observation that was likely driven by the high concentrations of pw. $\mathrm{SO}_{4}$ and pw.DOC fueling sulfate-reducing $\mathrm{Hg}(\mathrm{II})$-methylating microbial activity and consistent with the high sediment TRS concentrations and low sediment oxidation reduction potential (also known as redox; $\mathrm{E}_{\mathrm{h}}$ ) also observed at this site (figs. 5, 11, and 12B). The highest calculated MPP rates were at stream reaches AR4 and AR7 (fig. 10D). Interestingly, the elevated MPP rates at AR4 were driven by the high $\mathrm{k}_{\text {meth }}$ values, whereas the elevated MPP rates at AR7 were driven by high $\mathrm{Hg}(\mathrm{II})_{\mathrm{R}}$ concentrations (fig. 10A).

Not only was the absolute concentration of $\mathrm{Hg}(\mathrm{II})_{\mathrm{R}}$ greater downstream from the point source than at the reference site, but the concentration generally increased with distance downstream from the point source (fig. 10A). Far sites (8 to $16 \mathrm{~km}$ downstream from the point source) had significantly higher $\mathrm{Hg}(\mathrm{II})_{\mathrm{R}}$ concentrations in whole sediment than near sites (table 5, in back of report). Similarly, the bioaccumulation of mercury generally increased with distance downstream from the point source. THg concentrations in smallmouth bass and white sucker were significantly higher in far-stream reaches than near-stream reaches (table 5 , in back of report). Near-stream reaches are comparatively short and have a high gradient, whereas far-stream reaches are longer and lower in gradient (fig. 1). The longer, lower gradient far-stream reaches appear to have conditions more conducive to methylation than the high-gradient near-stream reaches, which may reflect a difference in the type and size of particles that are likely to be deposited in these two contrasting hydrologic settings and the effect that particles have on the speciation and availability of mercury deposited to the benthos.

\section{Controls on Mercury Distribution}

Using step-wise linear regression and beginning with potential explanatory variables of sediment organic carbon (measured as percent LOI), bulk density (BD), percent fines, and percent dry weight, the best single model of sediment 

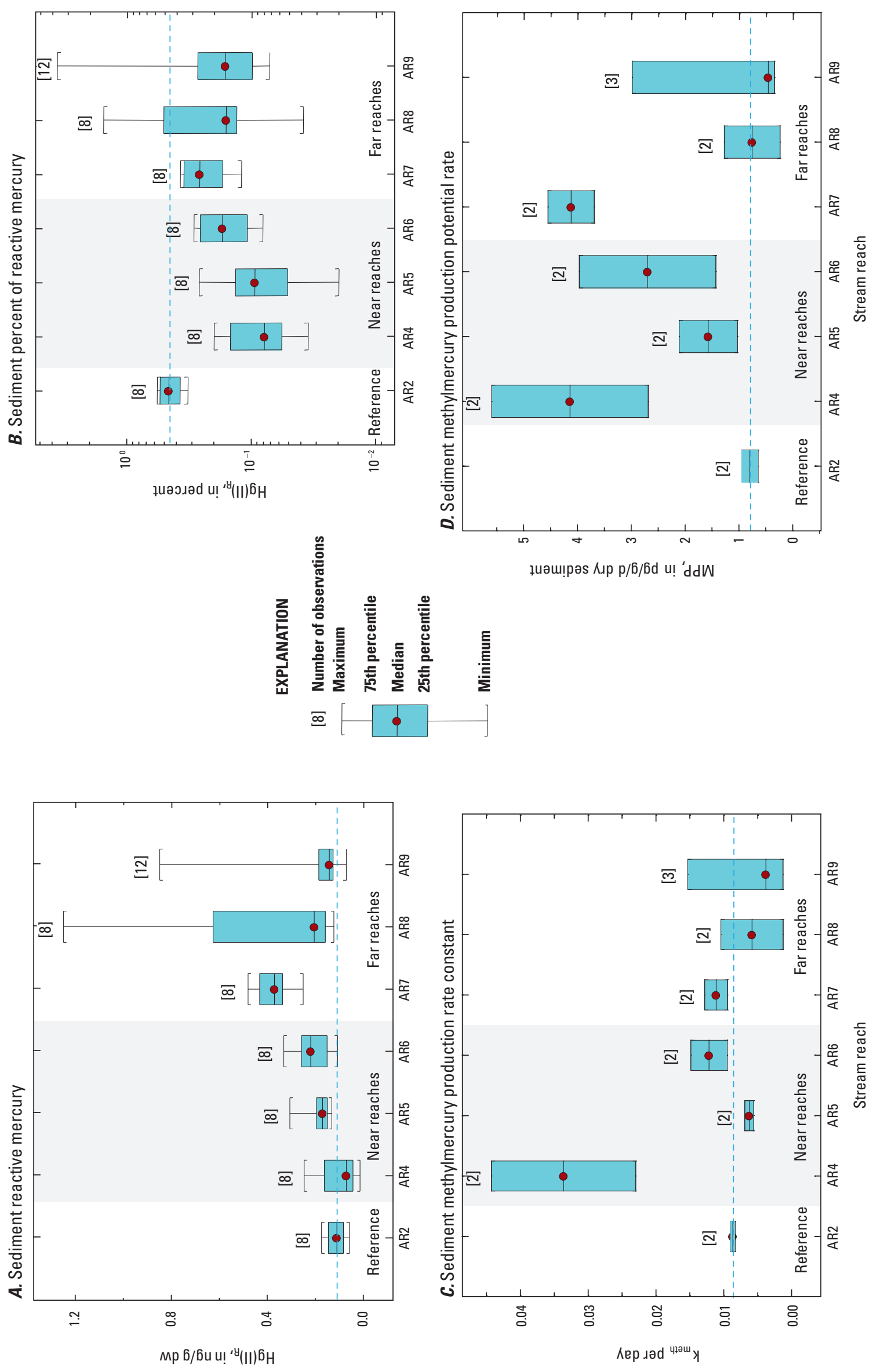

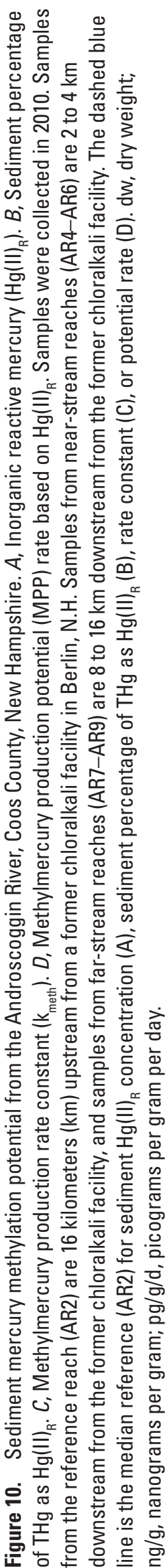



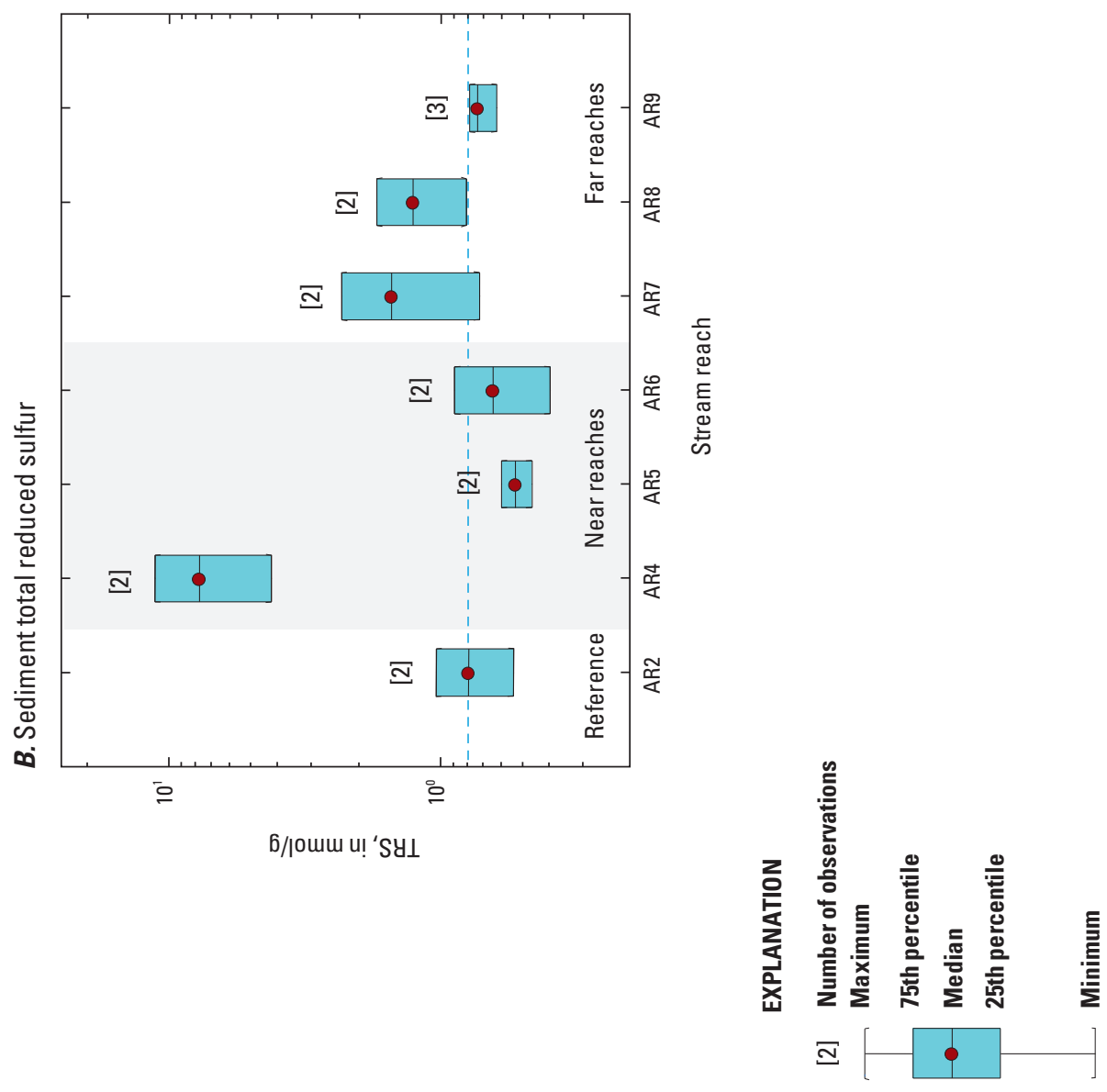
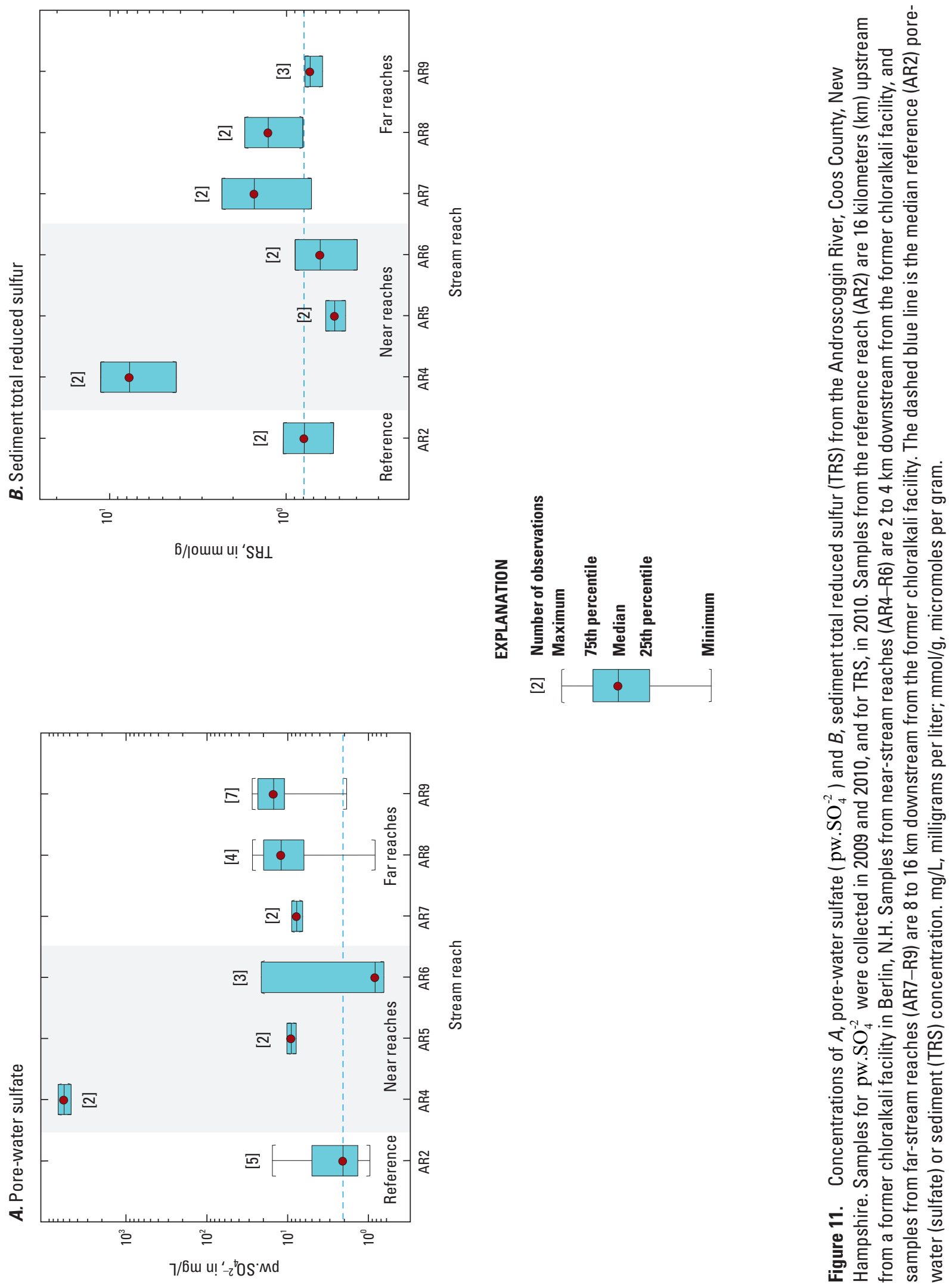

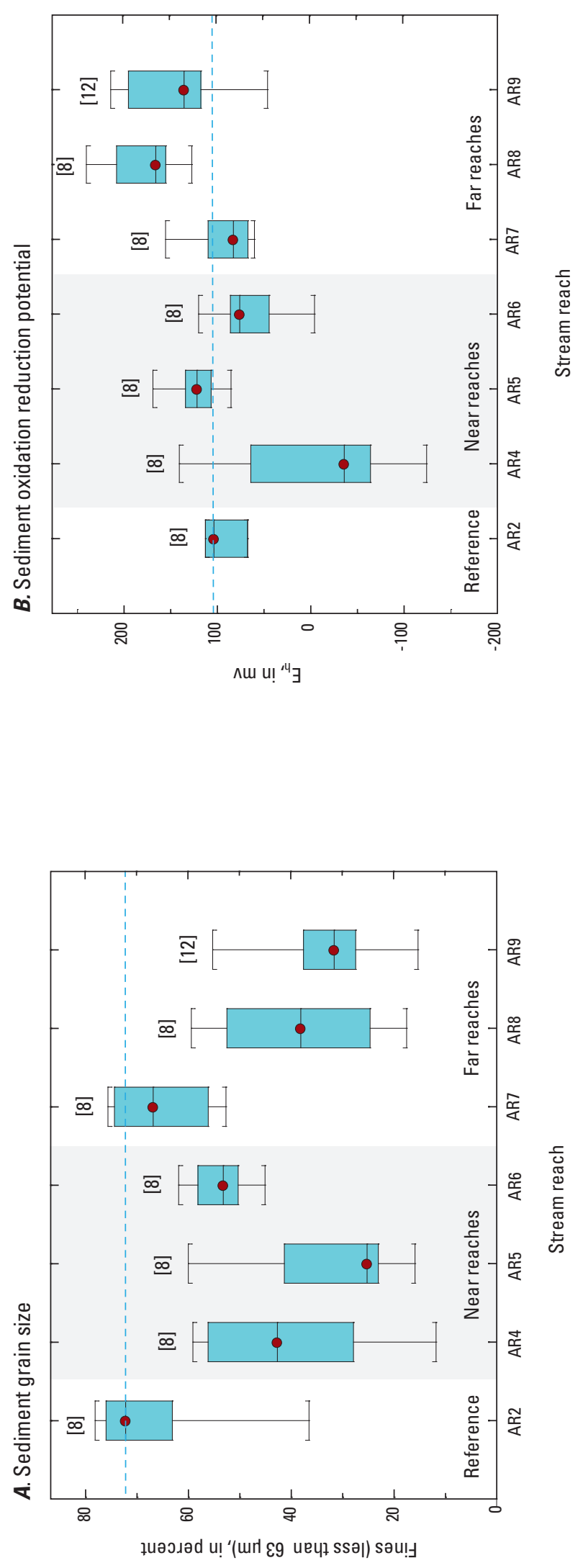

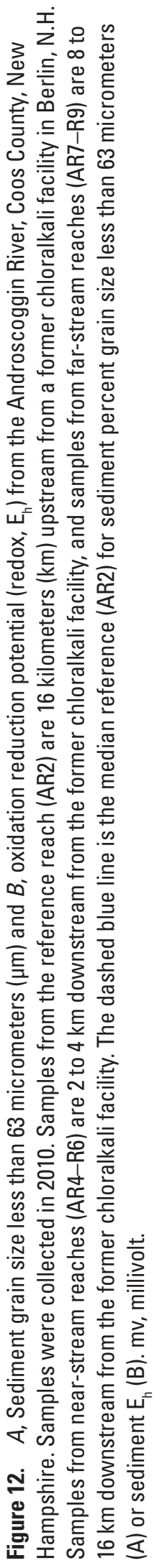


THg concentration throughout the whole study area included only percent $\mathrm{LOI}$ and $\mathrm{BD}$, although it had low explanatory power (coefficient of determination $\left(\mathrm{R}^{2}\right)$ of 0.19 ). However, by grouping the downstream study area into near (AR4, AR5, and AR6) and far (AR7, AR8, and AR9) stream reaches, regression models could explain 49 to 55 percent of the variability in $\mathrm{THg}$ concentration (fig. 13). In the far-stream reaches, percent LOI alone explained 49 percent of the variability in sediment $\mathrm{THg}$ concentration. A positive relation between $\mathrm{THg}$ and percent LOI has been observed in a number of other studies (Hammerschmidt and Fitzgerald, 2006; Han and others, 2007; Marvin-DiPasquale and others, 2009a, b). In the higher gradient near-stream reaches, sediment BD became an important explanatory variable in addition to percent LOI, alluding to the nature of the particles that are likely to be deposited in the high-gradient environment.

Sediment MeHg concentration across all stream reaches was best described as a positive function of sediment $\mathrm{THg}$ concentration and a negative function of sediment TRS concentration (fig. 14), when starting with $\mathrm{THg}, \mathrm{Hg}(\mathrm{II})_{\mathrm{R}}, \mathrm{k}_{\text {meth }}$, $\mathrm{E}_{\mathrm{h}}$, percent LOI, TRS, and percent fines as initial explanatory variables in the stepwise regression. Sediment $\mathrm{MeHg}$ and $\mathrm{THg}$ are often correlated at lower $\mathrm{THg}$ concentrations (Krabbenhoft and others, 1999; Kamman and others, 2005b; MarvinDiPasquale and others, 2009a; Scudder and others, 2009), as seen in this study. The negative relation between $\mathrm{MeHg}$ concentration and TRS concentration may reflect $\mathrm{Hg}$ (II) binding to solid-phase reduced sulfur compounds, thus reducing the amount of $\mathrm{Hg}$ (II) available for methylation (Huerta-Diaz and Morse, 1992; Marvin-DiPasquale and others, 2009a).

\section{Controls on Divalent Mercury Availability for Methylation}

Explanatory variables used in stepwise linear regression to describe controls on $\mathrm{Hg}(\mathrm{II})_{\mathrm{R}}, \mathrm{k}_{\text {meth }}$, and MPP included percent LOI, TRS, $\mathrm{E}_{\mathrm{h}}$, percent fines, and THg concentration. The availability of sediment $\mathrm{Hg}$ (II) for $\mathrm{Hg}$ (II)-methylation, as assessed by the $\mathrm{Hg}(\mathrm{II}) \mathrm{R}$ assay, was best described as a multivariable linear function of sediment $\mathrm{THg}$, percent fines, and $\mathrm{E}_{\mathrm{h}}$. Approximately 50 percent of the variability in sediment $\mathrm{Hg}(\mathrm{II})_{\mathrm{R}}$ could be explained by these three variables across all stream reaches, but 76 percent of $\mathrm{Hg}(\mathrm{II})_{\mathrm{R}}$ variability was accounted for in near-stream reaches alone using the same three variables (fig. 15). One-third of the variability in sediment $\mathrm{Hg}(\mathrm{II})_{\mathrm{R}}$ in far-stream reaches was explained by a combination of percent fines and $\mathrm{E}_{\mathrm{h}}$. Low variability in sediment THg concentrations appeared to make sediment THg a weak explanatory variable for sediment $\mathrm{Hg}(\mathrm{II})_{\mathrm{R}}$ in these stream reaches. The positive relation between sediment $\mathrm{Hg}(\mathrm{II})_{\mathrm{R}}$ and $\mathrm{E}_{\mathrm{h}}$ likely reflects the binding kinetics of inorganic $\mathrm{Hg}$ (II) to solidphase minerals and organics, which appear to increase under reducing conditions and decrease under more oxic conditions (Marvin-DiPasquale and Cox, 2007; Marvin-DiPasquale and others, 2009a, b). An increase in percent fines (a decrease in sediment grain size) reflects more surface area and solid-phase binding sites for $\mathrm{Hg}(\mathrm{II})$.

The activity of the in-situ $\mathrm{Hg}$ (II)-methylating microbial community, as assessed by $\mathrm{k}_{\text {meth }}$, was best predicted by $\mathrm{E}_{\mathrm{h}}$ alone $\left(\mathrm{R}^{2}=0.59\right.$; fig. 16). The highest $\mathrm{k}_{\text {meth }}$ values were measured at the most chemically reducing site (AR4), and the lowest $\mathrm{k}_{\text {meth }}$ values were measured at the two most oxidized sites (AR8 and AR9; fig. 10). The importance of reducing conditions for microbial $\mathrm{Hg}$ (II)-methylation has been documented in Morel and others (1998).

Calculated MPP rates were best modeled as a combined positive function of THg concentration and negative function of sediment $\mathrm{E}_{\mathrm{h}}$. Because MPP rates are a function of both microbial activity $\left(\mathrm{k}_{\text {meth }}\right)$ and in-situ $\mathrm{Hg}(\mathrm{II})$ availability, controls on $\mathrm{Hg}(\mathrm{II})_{\mathrm{R}}$ and $\mathrm{k}_{\text {meth }}$ would also apply to MPP. Sediment organic carbon (as percent LOI) was less of an explanatory variable for predicting $\mathrm{Hg}$ (II)-methylation in this study compared with other studies (Lambertsson and Nilsson, 2006; Marvin-DiPasquale and others, 2009a), reflecting the limited range of organic carbon concentrations in the study area (fig. 5).

\section{Controls on Partitioning between Bed Sediment and Pore Water}

The distribution of inorganic $\mathrm{Hg}$ (II) and $\mathrm{MeHg}$ between sediment particles (solid-phase) and pore water affects the availability of inorganic $\mathrm{Hg}(\mathrm{II})$ and $\mathrm{MeHg}$ for $\mathrm{Hg}(\mathrm{II})$-methylation and bioaccumulation, respectively. Grain size (Bloom and others, 1999) and organic content (Hammerschmidt and others, 2006; Sunderland and others, 2006) are often key factors in partitioning between pore water and sediment. Typically, partitioning of both THg and $\mathrm{MeHg}$ from sediment to pore water increases with increasing pw.DOC and decreasing percent fines (increasing grain size; Marvin-DiPasquale and others, 2009a). DOC contains strong mercury-binding ligands that increase mercury dissolution into pore water by stabilizing nanoparticles of compounds such as cinnabar (HgS; Slowey, 2010; Gerbig and others, 2011), whereas decreasing percent fines reduces particulate surface area and thus potential binding sites on sediments. The relation between the distribution coefficient for total mercury $\left(\mathrm{k}_{\mathrm{d}}[\mathrm{THg}]\right)$ and the ratio of pw.DOC to grain size [pw.DOC/ percent fines] was first described by Marvin-DiPasquale and others (2009a) for eight diverse nonpoint-source streams across the United States (in Florida, Wisconsin, and Oregon) as part of the USGS National Water Quality Assessment Program (NAWQA) mercury topical study. The same pw.DOC/percent fines ratio explained 44 and 40 percent of the variability in the partitioning coefficients for $\mathrm{THg}$ and $\mathrm{MeHg}$, respectively, in the Androscoggin River data (fig. 17).

Plotting the Androscoggin River data along with the NAWQA data (as $k_{d}[\mathrm{THg}]$ against the pw.DOC/percent fines ratio; both log-base-10-transformed), we find that the both datasets fall along the same line but that the majority of the 

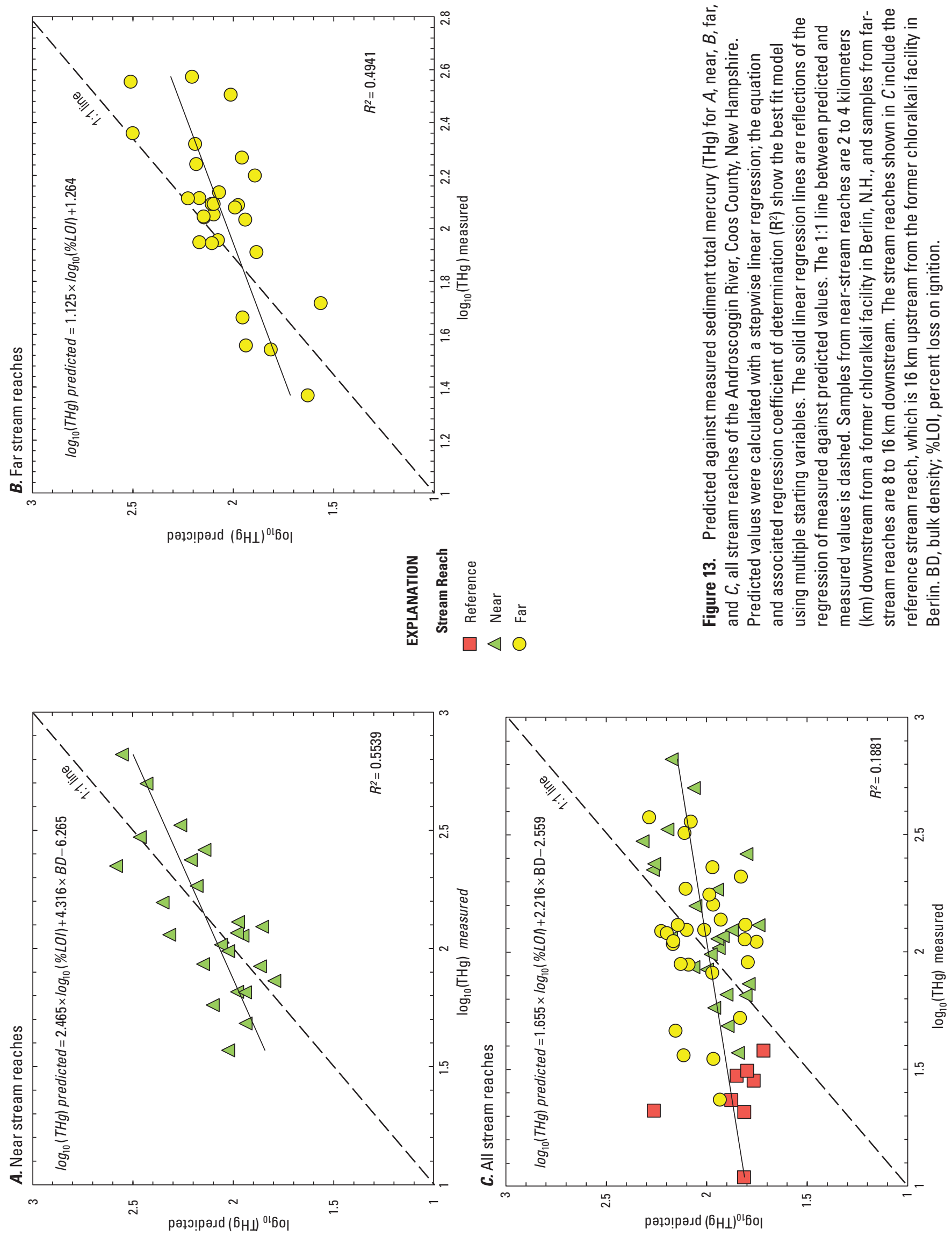


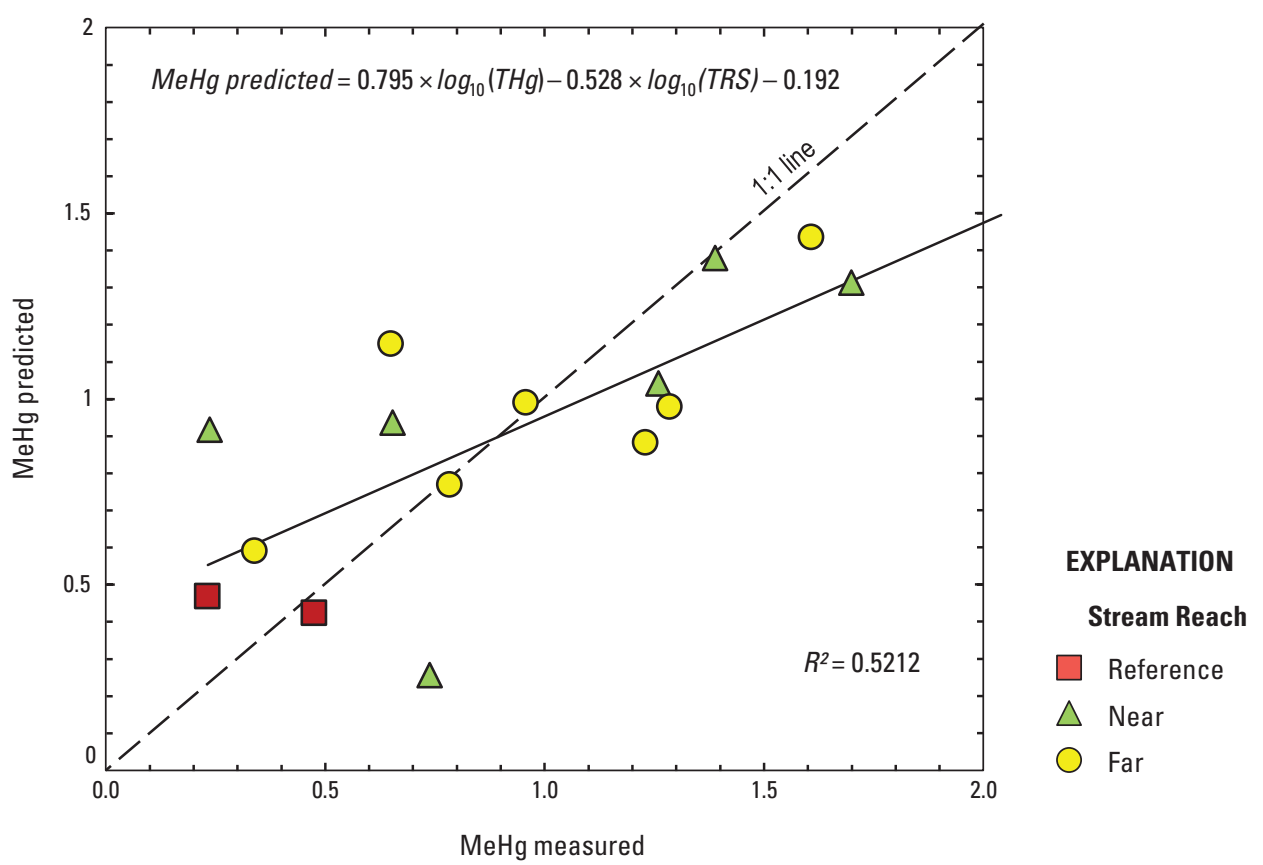

Figure 14. Predicted against measured methylmercury (MeHg) from the Androscoggin River, Coos County, New Hampshire. Predicted values were calculated with a stepwise linear regression; the equation and associated regression coefficient of determination $\left(R^{2}\right)$ show the best fit model using multiple starting variables. The solid linear regression line is a reflection of the regression of measured against predicted values. The 1:1 line between predicted and measured values is dashed. Samples from the reference stream reach are 16 kilometers $(\mathrm{km})$ upstream from a former chloralkali facility in Berlin, N.H. Samples from near-stream reaches are 2 to $4 \mathrm{~km}$ downstream from the former chloralkali facility, and samples from far-stream reaches are 8 to $16 \mathrm{~km}$ downstream from the former chloralkali facility. THg, total mercury; TRS, total reduced sulfur.

Androscoggin River data only occupies the upper one-third of the regression line (fig. 18). This suggests that, due to comparatively low pw.DOC or high percent fines (or some combination), THg in the Androscoggin River partitions to a greater extent onto sediment particles (larger $\mathrm{k}_{\mathrm{d}}[\mathrm{THg}]$ values). This would imply that $\mathrm{THg}$ (almost all as $\mathrm{Hg}(\mathrm{II})$ ) in the samples from the Androscoggin River was comparatively less available for $\mathrm{Hg}$ (II)-methylation than more than one-half of the sites from the earlier NAWQA study. In contrast, MeHg partitioning coefficients $\left(\mathrm{k}_{\mathrm{d}}[\mathrm{MeHg}]\right)$ for the Androscoggin River fell along a parallel line to those from the NAWQA study but were generally lower for the same pw.DOC/percent fines ratio (fig. 19). This implies that MeHg in the Androscoggin River partitions to a greater extent in pore water and may be more available for bioaccumulation into the food web compared with the nonpoint source streams sampled for the NAWQA mercury study.

\section{River-Reach Integrated Mercury Species Inventories and Methylmercury Production Potential Rates}

Stream reach integrated inventories of sediment $\mathrm{THg}$, $\mathrm{Hg}(\mathrm{II})_{\mathrm{R}}$, and $\mathrm{MeHg}$, as well as MPP rates, were calculated for each stream reach sampled during 2010. These calculations were based on stream reach-specific parameters (table 7), including total stream reach area, \%fine substrate (percentage of stream reach area with grain size less than 63 micrometers), stream reach-specific sediment percent dry weight (median from all samples collected for mercury analysis), stream reach-specific sediment bulk density (median from all samples collected for mercury analysis), and depth of fine substrate, as assessed with ground-penetrating radar (Degnan and others, 2011) in combination with a nonparametric analysis of the mercury species concentration data distribution (table 8), 

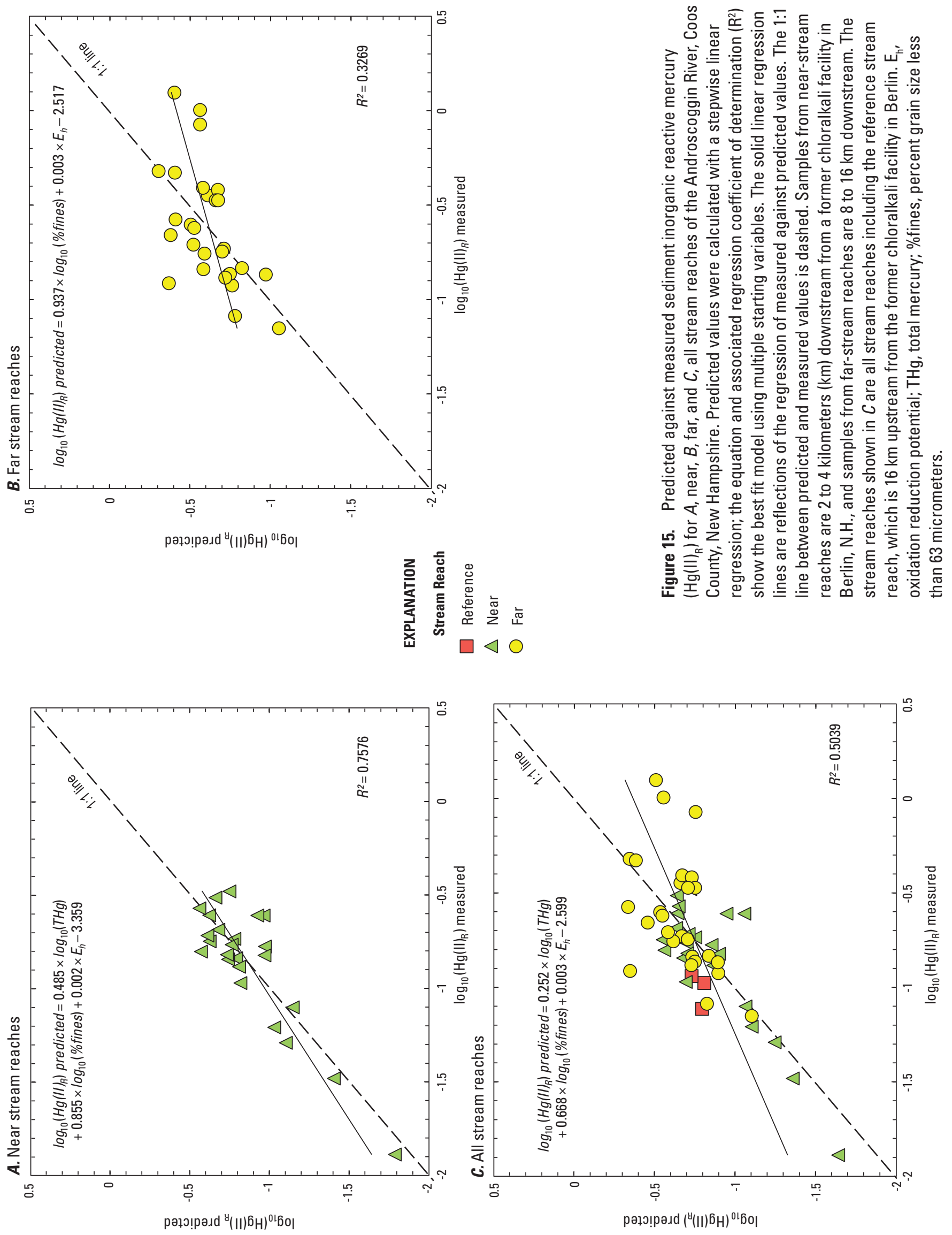

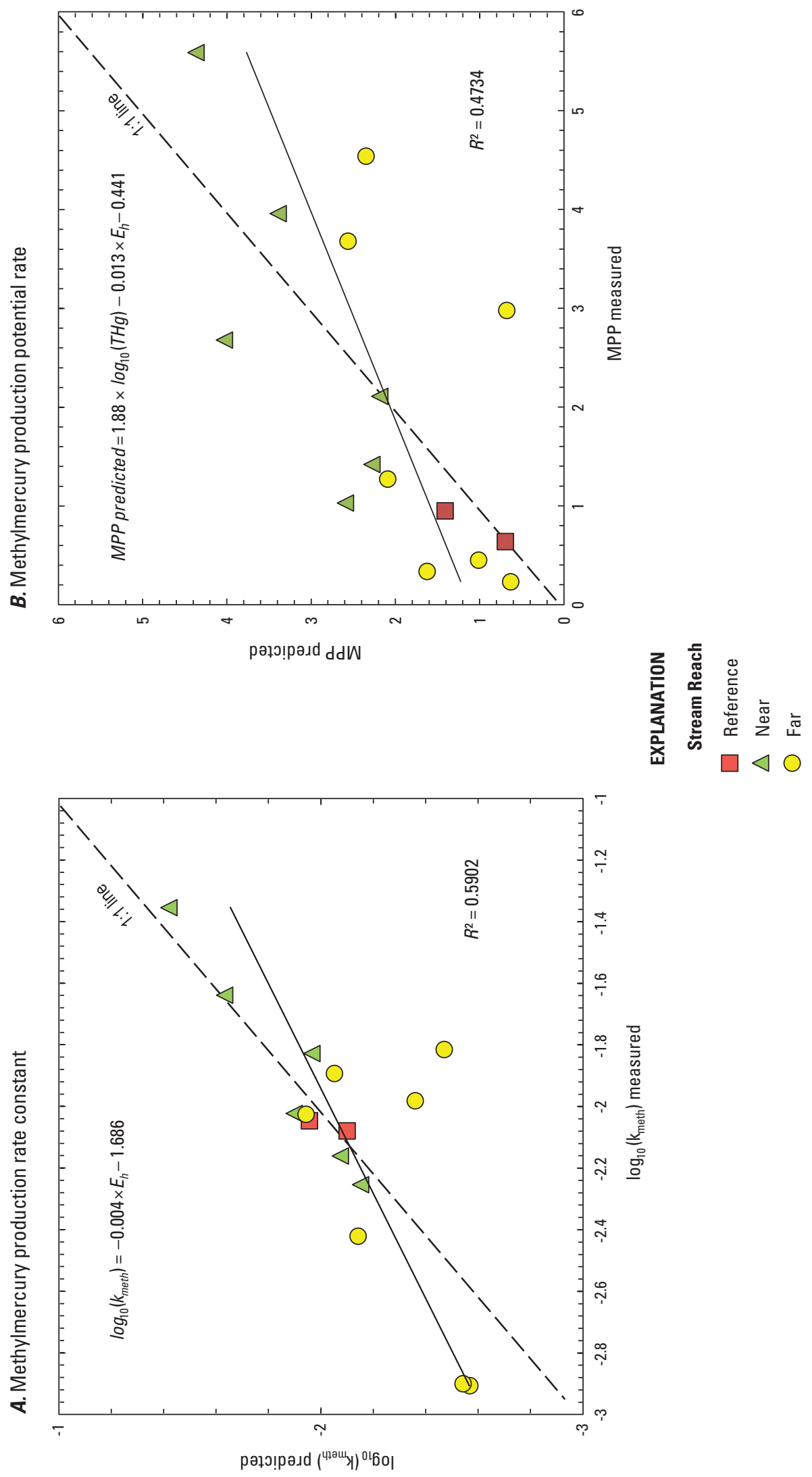

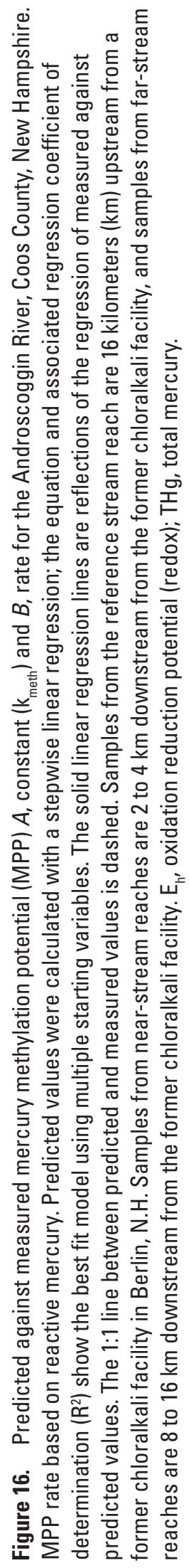



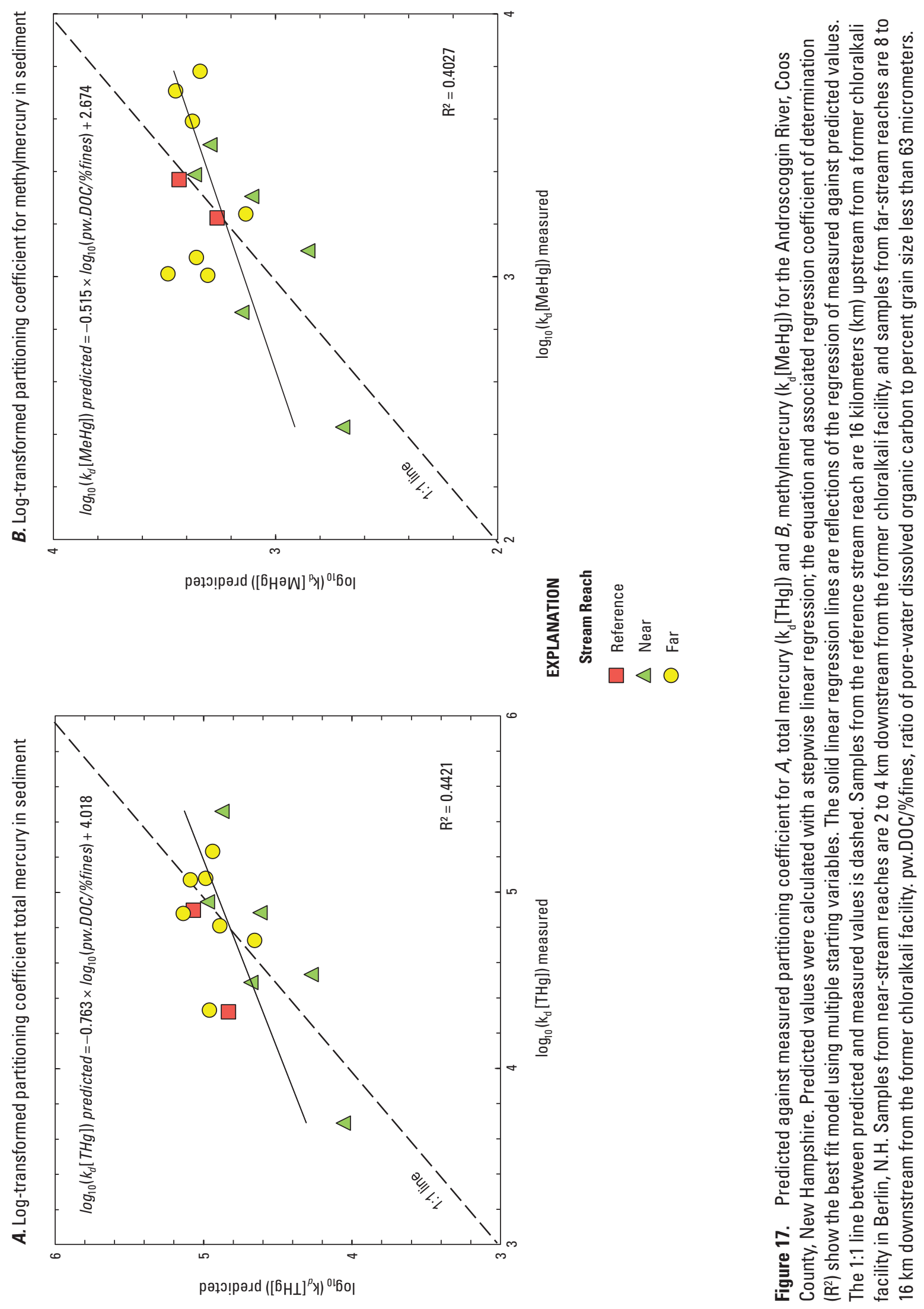


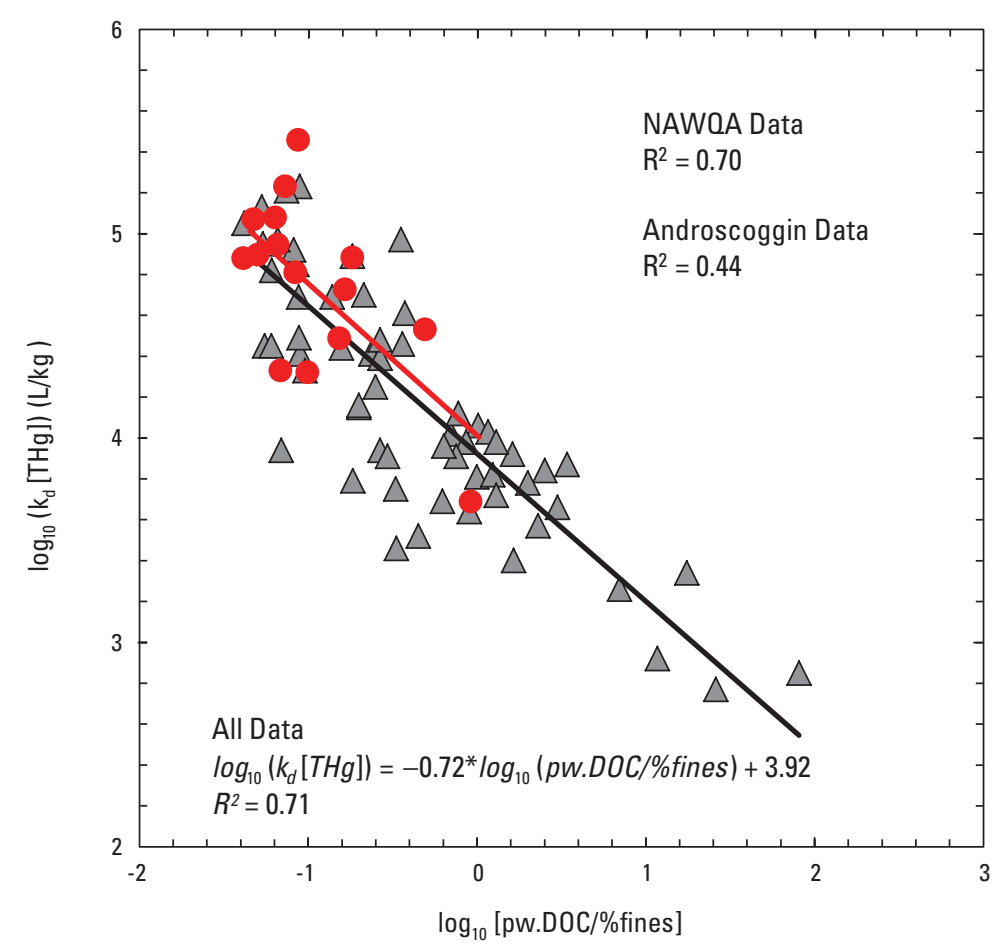

Figure 18. Sediment total mercury partitioning coefficient as a function of dissolved organic carbon and grain size. Sites on the Androscoggin River (red circles) are compared with sites sampled for the U.S. Geological Survey National Water-Quality Assessment Program (NAWQA, grey triangles) across the United States (Marvin-DiPasquale and others, 2008, 2009a). $k_{d}[\mathrm{THg}$, sediment total mercury partitioning coefficient; $\mathrm{L} / \mathrm{kg}$, liters per kilogram; pw.DOC/\% fines, ratio of dissolved organic carbon to percent grain size less than 63 micrometers; $\mathrm{R}^{2}$, coefficient of determination]
Figure 19. Sediment methylmercury partitioning coefficient as a function of dissolved organic carbon and grain size. Sites on the Androscoggin River (red circles) are compared with sites sampled for the U.S. Geological Survey National Water-Quality Assessment Program (NAWQA, grey triangles) across the United States (Marvin-DiPasquale and others, 2008, 2009a). $k_{d}[\mathrm{MeHg}$, sediment methylmercury partitioning coefficient; $\mathrm{L} / \mathrm{kg}$, liters per kilogram; pw.DOC/\% fines, ratio of dissolved organic carbon to percent grain size less than 63 micrometers; $R^{2}$, coefficient of determination]

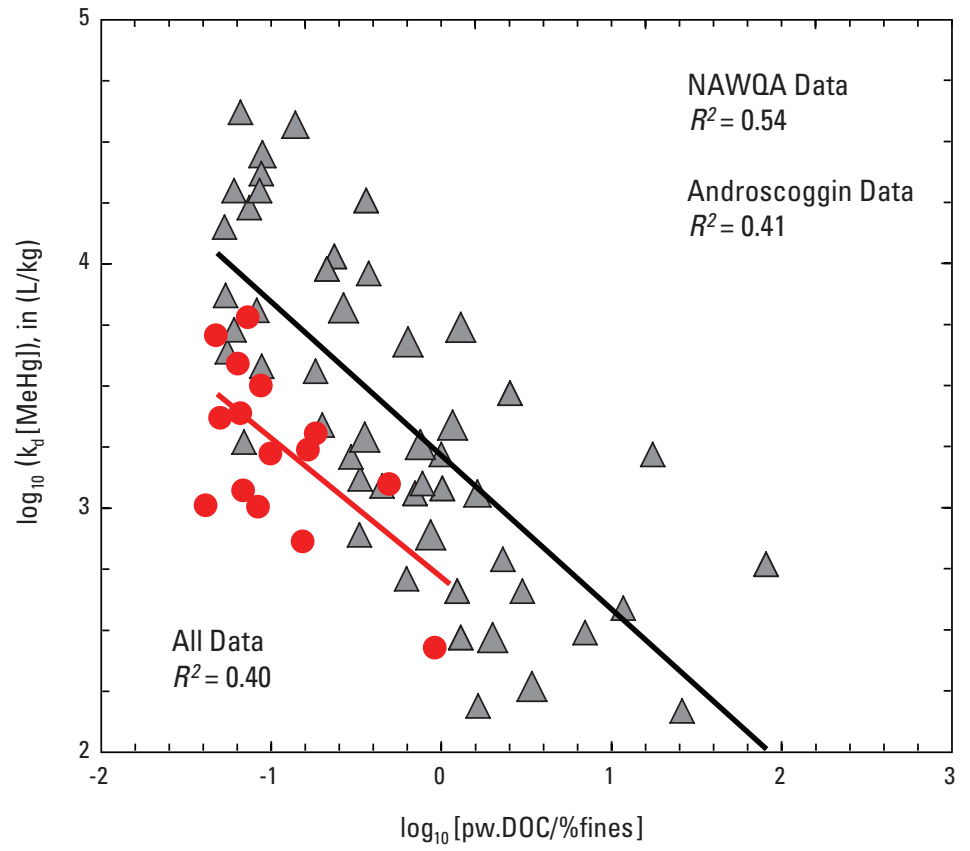


Table 7. Stream reach parameters used to calculate reach specific depth integrated mercury species inventories and rates.

[Stream reach area data are from Degnan and others (2011). Median sediment dry weight (dw) and bulk density were calculated from 2010 data only. Median depth of fine substrate was calculated excluding unknown (zero) observations. $\mathrm{m}^{2}$, square meters; $\mathrm{g} / \mathrm{cm}^{3} \mathrm{ww}$, grams of wet weight per cubic centimeter; $\mathrm{m}$, meters]

\begin{tabular}{|c|c|c|c|c|c|c|}
\hline Reach & Description & $\begin{array}{l}\text { Reach area, } \\
\text { in } \mathrm{m}^{2}\end{array}$ & $\begin{array}{l}\text { Fine substrate, } \\
\text { in percent of area }\end{array}$ & $\begin{array}{l}\text { Median sediment, } \\
\text { in percent dw }\end{array}$ & $\begin{array}{l}\text { Median sediment } \\
\text { bulk density, } \\
\text { in } \mathbf{g} / \mathbf{c m}^{3} \text { ww }\end{array}$ & $\begin{array}{l}\text { Median depth of sand, } \\
\text { silt, and clay layer, } \\
\text { in } \mathrm{m}\end{array}$ \\
\hline AR2 & Wheeler Bay & 89,108 & 55.6 & 47.2 & 1.37 & 1.18 \\
\hline AR5 & Upstream of Power Dam & 53,662 & 10 & 71.7 & 1.73 & 0.95 \\
\hline AR9 & Gorham Dam to Shelburne Dam & 696,373 & 45.7 & 64.4 & 1.6 & 1.07 \\
\hline
\end{tabular}

quartile distribution, and medians and 25 to 75 percent interquartile data. A simplifying assumption used in the calculation was that mercury species concentrations and MPP rates were zero for any substrate coarser than sand. Because large areas within each stream reach had substrate coarser than sand (table 7), it is likely that this simplifying assumption resulted in these inventories underestimating the actual amount of mercury species and MPP rates in each case and should be considered as minimum estimates. All mercury species inventories and MPP rates were first calculated for the top $10 \mathrm{~cm}$ only because that was the actual sediment sampling depth. A second simplifying assumption was that $\mathrm{THg}$ and $\mathrm{Hg}(\mathrm{II})_{\mathrm{R}}$ concentrations were constant with sediment depth. As such, we then calculated the stream reach-specific THg and $\mathrm{Hg}(\mathrm{II})_{\mathrm{R}}$ inventories for the full depth of the fine substrate, based on the median depth for the given reach (table 7).

Concentrations of mercury species and MPP rates, on a sediment dry weight basis, were higher in stream reaches downstream from the point source (figs. 3A, B, 10A and D; table 8). Whereas the distribution of sediment dry weight concentrations reflected the relative location of the sampling sites to the point source, stream reach-specific mercury inventories reflected the amount depositional environments with fine-grained sediment in each reach. AR9 was the largest stream reach sampled and had the largest percentage of area as fine substrate downstream from the point source (table 7). These geophysical conditions resulted in mercury inventories (total mass) being much larger in reach AR9 than in any other reach (table 8). In contrast, reach AR4 had the smallest area and the fourth smallest areal percentage of fine substrate (table 7), and as a consequence, typically had the smallest calculated mercury species inventories. For the top 0 - to 10 -cm-depth interval, median mercury inventory range estimates for all stream reaches downstream from the point source were as follows: THg, 0.03 to 2.91 kilograms (kg);
$\mathrm{Hg}(\mathrm{II})_{\mathrm{R}}, 0.03$ to 4.64 grams (g); $\mathrm{MeHg}, 0.20$ to $32.9 \mathrm{~g}$; and MPP rate, 1.10 to 14.8 milligrams per day (mg/d). On the basis of the median depth of the fine deposits in each reach, the median mass inventories for $\mathrm{THg}$ and $\mathrm{Hg}(\mathrm{II})_{\mathrm{R}}$ ranged from 0.21 to $31.0 \mathrm{~kg}$ and 0.19 to $49.4 \mathrm{~g}$, respectively (table 8).

\section{Ecological Impact}

The health of the aquatic ecosystem that was potentially affected by the former chloralkali facility was evaluated using a variety of toxicity tests, biological indices, and guidelines. Results of pore-water and surface-water bioassays are detailed in Environmental Services Assistance Team (2009a, b, respectively), and bulk sediment bioassays, in EnviroSystems, Inc., (2010a, b). Survival and growth of Hyalella azteca and Chironomus dilutus in sediment and survival of Hyalella azteca and Chironomus tentans in pore water collected downstream from the former chloralkali facility were not significantly different from the reference site (table 5, in back of report). Survival and reproduction of Ceriodaphnia dubia and survival and growth of Pimephales promelas provided no evidence of toxicity of surface water collected downstream from the former chloralkali site (table 2-13; Environmental Services Assistance Team, 2009b); however, the number of samples $(\mathrm{n}=5)$ collected did not allow for statistical testing.

Sites were evaluated for biological condition based on scores calculated with the use of the NHDES B-IBI for invertebrate assemblages (table 2-17). The B-IBI is designed to provide a relative measure of stream health and is centered on the mean (average) value of seven indicator metrics that reflect the biological condition of streams and rivers in the region, including the Androscoggin River. The Androscoggin River reaches AR2 through AR9 were classified as being exclusive to the Hills reference sites. The 25th percentile (64.5) for 


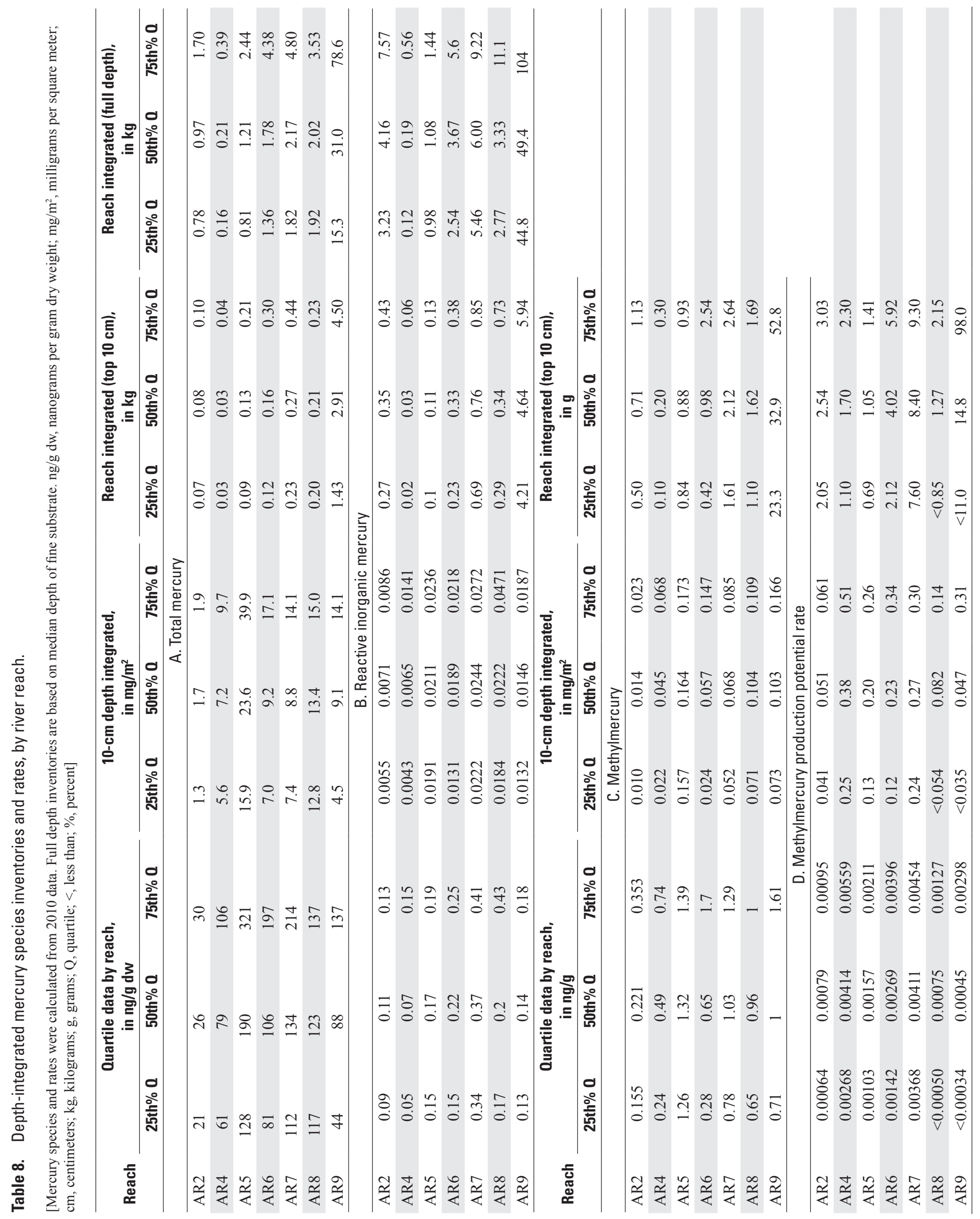


Hills reference sites is operationally defined as the threshold, and 90 percent (58) of the threshold categorizes the stream as unimpaired for the NHDES listing of impaired waters (Neils, NHDES, 2007). The B-IBI integrates the following metrics, which are denoted with $(+)$ to indicate where values increase with improving conditions and (-) to indicate where values decrease with improving conditions:

- total taxa richness $(+)$

- plecoptera (stoneflies) taxa $(+)$

- percent chironomidae (midge) taxa (-)

- percent noninsect taxa (-)

- tolerant taxa (-)

- percent intolerant (sensitive) taxa $(+)$

- percent clinger taxa $(+)$

For (-) metrics that decrease with improving conditions, the inverse values were used in calculating the B-IBI score so that these metrics would contribute to the B-IBI increasing with improving condition. All replicates at all sites exceeded the B-IBI threshold of 58, indicating that the sites were categorized as meeting the criteria for unimpaired streams by
NHDES standards (fig. 20; David Neils, NHDES, written commun., April 2011).

Jaccard's indices were used to compare species diversity within and between stream reaches. The percentage of similarity within stream reaches was $51 \pm 9$ (average plus or minus $( \pm$ ) standard deviation). This compares closely to the percentage of similarity among stream reaches AR2, AR3, AR8, and AR9 $(55 \pm 5)$. AR4 was the most different from other stream reaches with the percentage of similarity equal to $35 \pm 2$. This section of the river is highly regulated, and the rock baskets were not in flowing water the entire 6.5 weeks they were in the river. Jaccard's indices did not show differences in species diversity upstream and downstream from the point source; however, Jaccard's indices did suggest flow characteristics were a major factor controlling species diversity in the study area.

Differences in total abundance, total taxa, and Ephemeroptera, Plecoptera, Trichoptera (EPT) taxa between invertebrate assemblages upstream and downstream from the point source were compared using nonparametric WRS and KWRS tests. The total abundance of organisms is a general indicator of productivity, whereas total taxa and EPT taxa are two indicators of taxonomic complexity in the assemblages. The highest total abundance occurred at AR3 adjacent to the former chloralkali facility (table 2-17). The higher abundance

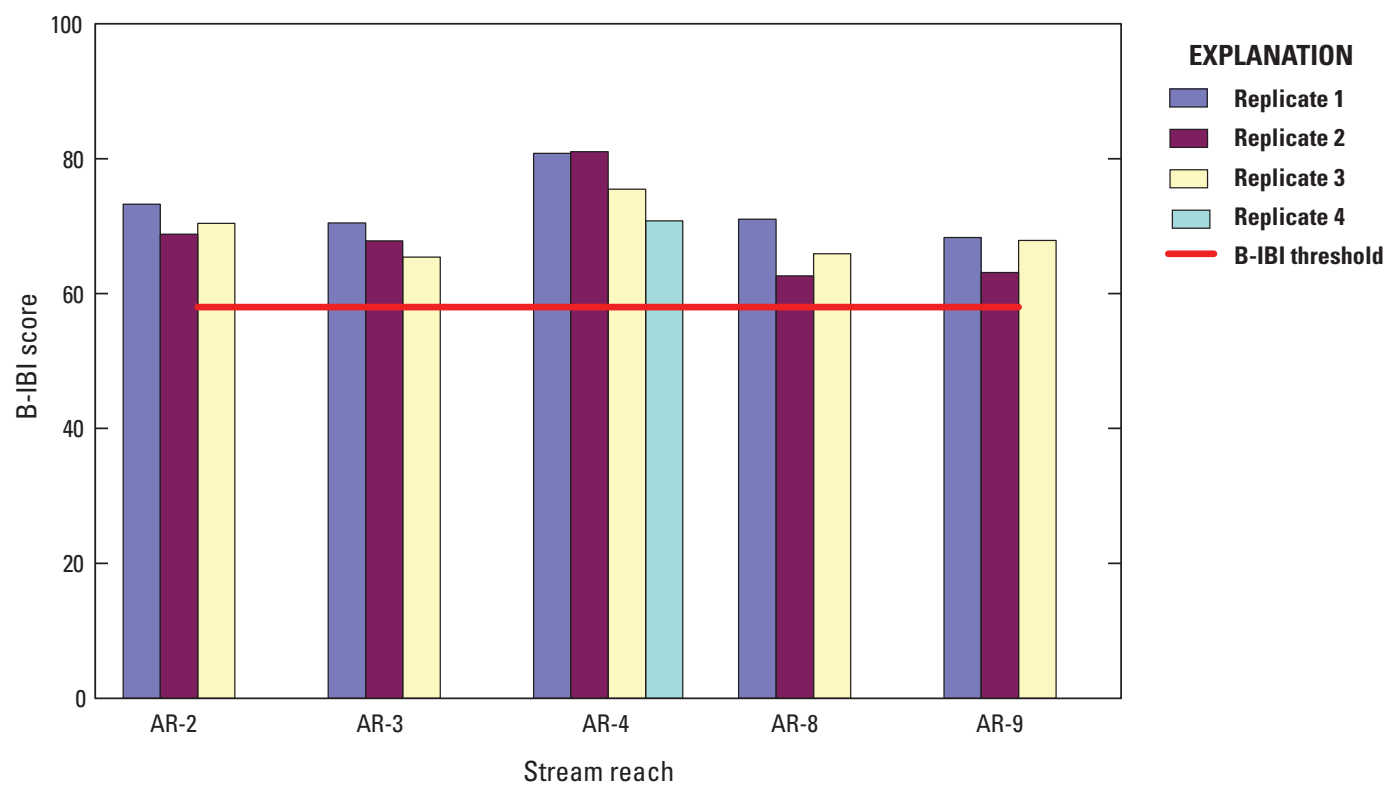

Figure 20. New Hampshire Department of Environmental Services (NHDES) benthic index of biotic integrity (B-IBI) for the Androscoggin River, Coos County, New Hampshire. The reference reach (AR2) is 16 kilometers $(\mathrm{km})$ upstream from a former chloralkali facility in Berlin, N.H., and stream reaches AR3, $A R 4, A R 8$, and $A R 9$ are 0 to $16 \mathrm{~km}$ downstream from the former chloralkali facility. Three replicate samples were collected at AR2, AR3, AR8, and AR9, and four replicate samples at AR4. The NHDES B-IBI threshold is 58. Stream reaches that score higher than the B-IBI threshold are categorized as unimpaired. 
at AR3 compared with other sites was mainly due to greater abundance of Diptera Simuliidae Simulium, which presumably favored the steady low-flow water conditions at this site. Abundance downstream from the point source was not significantly different from the reference site (table 4 , in back of report). Total taxa (the total number of taxa in the sample) and EPT taxa (taxa in the generally more environmentally sensitive orders Ephemeroptera (mayflies), Plecoptera, and Trichoptera (caddisflies)) were both highest at AR9 (table 5, in back of report); however, there was no significant difference in either metric among the spatial grouping of far (AR8, AR9), near (AR3, AR4), or reference (AR2) stream reaches.

Surface-water $\mathrm{THg}$ and $\mathrm{MeHg}$ concentrations in the Androscoggin River were all below the Canadian guideline for the protection of aquatic life (table 9; Canadian Council of Ministers of the Environment, 1999). One surfacewater THg concentration exceeded the 30-day standard of $1.3 \mathrm{ng} / \mathrm{L}$ set by the USEPA for Great Lakes fish-eating wildlife (U.S. Environmental Protection Agency, 1995). Sediment THg concentrations did not exceed the $1,060 \mathrm{ng} / \mathrm{g}$ dry weight consensus-based probable effect concentration (PEC) for adverse effects to benthic organisms in any sample (MacDonald and others, 2000), but one-quarter of the sediment samples did exceed the $180 \mathrm{ng} / \mathrm{g}$ dry weight consensus-based threshold effects concentration (TEC) for adverse effects to benthic organisms (MacDonald and others, 2000) and the $170 \mathrm{ng} / \mathrm{g}$ Canadian interim sediment quality guidelines (ISQG) for the protection of aquatic life (Canadian Council of Ministers of the Environment, 1999). The Wheeler Bay reference site was the only site that had no sediment sample with concentrations above the TEC and ISQG guidelines, and only AR5 had a median sediment THg concentration higher than the TEC and ISQG guidelines. Whereas water and sediment $\mathrm{THg}$ were mostly below guidelines, smallmouth bass $\mathrm{THg}$ concentrations in all samples (table 9) were higher than guidelines set for fish-eating birds (13 ng/g, kingfisher; Sample and others, 1996), fish-eating mammals (79 ng/g, river otter; Sample and others, 1996), and human health (140 ng/g; U.S. Environmental Protection Agency, 2001c, 2009).

\section{Comparison to Other Studies}

Data from the Androscoggin River were compared with datasets from the Northeastern Ecosystems Research Cooperative (NERC) and the USGS NAWQA (Kamman and others, 2005a, b; Shanley and others, 2005; Bauch and others, 2009). The NERC dataset is a compilation of regional stream data from New England, New York, Quebec, Ontario, and the Atlantic provinces of Canada, whereas the NAWQA dataset includes stream data from across the United States. Grouped medians from the Androscoggin River, the NERC, and the NAWQA datasets were compared using a KWRS test. For purposes of comparison, Androscoggin River smallmouth bass $\mathrm{THg}$ data from the NERC dataset were combined with data from the study of this report. Androscoggin River sediment $\mathrm{THg}$ concentrations were not significantly different than concentrations in the regional or national surveys. Sediment from the Androscoggin River had significantly lower $\mathrm{MeHg}$ concentrations than other streams in the Northeastern region but similar $\mathrm{MeHg}$ concentrations to streams across the country (table 10). However, comparisons between the surficial sediment from the Androscoggin River study and from other studies may have some bias because the sediment in the Androscoggin River study was sampled to $10 \mathrm{~cm}$, whereas sediments in the NERC and NAWQA studies were generally sampled to $2 \mathrm{~cm}$ and never deeper than $5 \mathrm{~cm}$. The greater sampling depth of the Androscoggin sediments could have a diluting effect, lowering $\mathrm{THg}$ and $\mathrm{MeHg}$ concentrations relative to the other surveys. Smallmouth bass $\mathrm{THg}$ concentrations from the Androscoggin River downstream from the point source were significantly higher than smallmouth bass from across the country, but only smallmouth bass from the furthest downstream stream reaches (AR7-AR9) were significantly higher than smallmouth bass from the Northeastern region studies (table 10). Surface-water THg and $\mathrm{MeHg}$ concentrations from the Androscoggin River study were similar to those from regional and national studies that focused on uncontaminated or nonpoint source lotic systems; however, the number of observations was too small $(n=1-2)$ for statistical evaluation. 
Table 9. Guidelines for total mercury in surface water, sediment, and fish and methylmercury in surface water.

[Guidelines are listed with the percentage of samples from the Androscoggin River that exceeded the guideline shown in brackets. Methylmercury (MeHg) guidelines are used for fish-eating wildlife and human health because more than 95 percent of mercury in smallmouth bass is MeHg. ng/L, nanograms per liter; dw, dry weight; THg, total mercury; ng/g, nanograms per gram; ww, wet weight; --, no data]

\begin{tabular}{|c|c|c|c|c|}
\hline \multirow{2}{*}{ Guideline } & \multicolumn{2}{|c|}{$\begin{array}{l}\text { Unfiltered surface water, } \\
\text { in ng/L }\end{array}$} & \multirow{2}{*}{$\begin{array}{l}\text { THg surfical sediment, } \\
\text { in } \mathbf{n g} / \mathbf{g ~ d w}\end{array}$} & \multirow{2}{*}{$\begin{array}{l}\text { THg smallmouth bass fillet, } \\
\text { in } n g / g \text { ww }\end{array}$} \\
\hline & $\mathrm{THg}$ & $\mathrm{MeHg}$ & & \\
\hline Aquatic life ${ }^{2}$ & $26[0]$ & $4[0]$ & $170[25]$ & -- \\
\hline Threshold effects level ${ }^{3}$ & -- & -- & $180[23]$ & -- \\
\hline Human health ${ }^{5}$ & -- & -- & -- & $140[100]$ \\
\hline
\end{tabular}

${ }^{1}$ U.S. Environmental Protection Agency, 1995a.

${ }^{2}$ Canadian Council of Ministers of the Environment, 1999.

${ }^{3}$ MacDonald and others, 2000.

${ }^{4}$ Sample and others, 1996.

${ }^{5}$ U.S. Environmental Protection Agency, 2001c, 2009.

Table 10. Comparison of mercury concentrations in the Androscoggin River, Coos County, New Hampshire, with National WaterQuality Assessment Program and Northeastern Ecosystem Research Cooperative datasets.

[Mercury concentrations are median values; values in bold are statistically different. Letters A, B, and C, indicate which medians are different: A medians are statistically different than $\mathrm{B}$ medians, $\mathrm{AB}$ medians are not statistically different than $\mathrm{A}$ or $\mathrm{B}$ but are different from $\mathrm{C}$, and $\mathrm{ABC}$ indicates medians are not statistically different than A, B, or C. The nonparametric Kruskal-Wallis rank sum test was run only for sites with at least five samples. Data are from streams only. Numbers in brackets are the number of samples from each site. Data for the Northeastern Ecosystem Research Cooperative (NERC) study were collected from 1983 through 2002; data for the National Water-Quality Assessment Program study were collected from 1998 through 2005; data for the Androscoggin River study were collected from 2009 through 2011. Surficial sediments are from the top 10 centimeters $(\mathrm{cm})$ in the Androscoggin study and the top 2 or $5 \mathrm{~cm}$ in other studies. For purposes of comparison, all smallmouth bass lengths were restricted to 25 to $38 \mathrm{~cm}$, and data for smallmouth bass from the NERC dataset have been combined with the Androscoggin River study data. All smallmouth bass samples are fillets. THg, total mercury; MeHg, methylmercury; dw, dry weight; $\mathrm{ng} / \mathrm{g}$, nanograms per gram; ng/L, nanograms per liter; ww, wet weight]

\begin{tabular}{|c|c|c|c|c|c|c|c|c|}
\hline Site location & $\begin{array}{l}\text { THg unfiltered } \\
\text { surface water, } \\
\text { in ng/L }\end{array}$ & $\begin{array}{l}\text { MeHg unfiltered } \\
\text { surface water, } \\
\text { in ng/L }\end{array}$ & $\begin{array}{l}\text { THg surfic } \\
\text { sediment } \\
\text { in } \mathrm{ng} / \mathrm{g} \mathrm{du}\end{array}$ & & $\begin{array}{c}\text { MeHg surfica } \\
\text { sediment, } \\
\text { in } \mathrm{ng} / \mathrm{g} \mathrm{dw}\end{array}$ & & $\begin{array}{r}\text { THg smallr } \\
\text { bass fill } \\
\text { in } \mathrm{ng} / \mathrm{g} \mathrm{v}\end{array}$ & $\begin{array}{l}\text { outh } \\
\text { t, } \\
\text { w }\end{array}$ \\
\hline \multicolumn{9}{|c|}{ Androscoggin River data } \\
\hline Upstream of point source & $1.00[1]$ & $0.05[1]$ & 30 [11] & $\mathrm{AB}$ & $0.23[5]$ & $\mathrm{B}$ & $418[10]$ & $\mathrm{ABC}$ \\
\hline Downstream near point source & $1.02[2]$ & $0.05[2]$ & $117[25]$ & $\mathrm{AB}$ & $0.74[7]$ & B & $528[26]$ & $\mathrm{AB}$ \\
\hline Downstream far from point source & $1.30[2]$ & $.06[2]$ & $111[35]$ & $\mathrm{AB}$ & $0.98[14]$ & $\mathrm{B}$ & $599[28]$ & A \\
\hline Northeastern North America ${ }^{1,2,3}$ & $2.20[388]$ & $0.20[101] \quad \mathrm{A}$ & $160[182]$ & A & $2.70[69]$ & A & 410 [179] & $\mathrm{B}$ \\
\hline United States ${ }^{4}$ & $2.06[287]$ & $0.09[288] \quad \mathrm{B}$ & $25.4[296]$ & $\mathrm{B}$ & $0.40[295]$ & B & $273[46]$ & $\mathrm{C}$ \\
\hline
\end{tabular}

${ }^{1}$ Shanley and others, 2005.

${ }^{2}$ Kamman and others, 2005b.

${ }^{3}$ Kamman and others, 2005a.

${ }^{4}$ Bauch and others, 2009. 


\section{Summary and Conclusions}

During operation of the chloralkali facility in Berlin, New Hampshire, elemental mercury $\left(\mathrm{Hg}^{0}\right)$ was spilled into the Androscoggin River, contaminating the overburden and underlying fractured rock on the east (left) bank of the Androscoggin River. In September 2005, Congress added the former chloralkali facility in Berlin to the national priorities list, commonly known as the Superfund list. Mercury contamination from historical paper and saw mill activities represents a significant potential risk to human health and the environment.

Total mercury (THg) and methylmercury (MeHg) concentrations in Androscoggin River sediment, pore water, and biota were elevated downstream from the former chloralkali facility relative to reference sites. Sequential extraction of surface sediment showed a distinct difference in mercury speciation upstream compared with downstream from the former chloralkali facility. The reference site was dominated by potassium hydroxide-extractable $\mathrm{THg}$ consistent with organic mercury or particle-bound divalent mercury $(\mathrm{Hg}(\mathrm{II}))$, whereas sites downstream from the point source were dominated by concentrated nitric acid-extractable $\mathrm{THg}$, indicative of $\mathrm{Hg}^{0}$ or mercurous chloride. Mercury metrics from the study indicated $\mathrm{Hg}(\mathrm{II})$ at the reference site was more available for $\mathrm{Hg}$ (II)methylation compared with sites downstream from the point source, but the absolute concentrations of whole sediment $\mathrm{Hg}(\mathrm{II})_{\mathrm{R}}$ and $\mathrm{THg}$ in biota were greater downstream from the point source. In addition, whole sediment $\mathrm{Hg}(\mathrm{II})_{\mathrm{R}}$ and smallmouth bass THg concentrations appeared to increase further downstream from the point source. The furthest downstream reach (AR9 from Gorham Dam to Shelburne Dam) had larger mass of fine sediment and larger estimated mass inventory of mercury species than any other stream reach by an order of magnitude for both masses.

Sediment organic carbon and bulk density were the dominant influences on sediment THg distribution. The availability of $\mathrm{Hg}(\mathrm{II})$ for methylation was best described as a positive function of sediment $\mathrm{THg}$, percent fines, and sediment oxidation reduction potential (redox; $\mathrm{E}_{\mathrm{h}}$ ). The microbial activity associated with $\mathrm{Hg}(\mathrm{II})$-methylation (as measured by the mercury methylation potential (MPP) constant $\left(\mathrm{k}_{\text {meth }}\right)$ ) was best described by $\mathrm{E}_{\mathrm{h}}$ alone. MPP was primarily a function of sediment $\mathrm{THg}$ concentration and $\mathrm{E}_{\mathrm{h}}$.

Toxicity tests and invertebrate community assessment suggest that impairment of invertebrates is not occurring at the current (2009 and 2010) levels of mercury contamination downstream from the point source. Concentrations of $\mathrm{THg}$ and $\mathrm{MeHg}$ in most water and sediment samples from the Androscoggin River were below Federal and consensus-based guidelines, whereas smallmouth bass mercury concentrations were above U.S. Environmental Protection Agency and regional guidelines in all samples. Smallmouth bass $\mathrm{THg}$ concentrations from the Androscoggin River downstream from the point source were significantly higher than those reported in a national survey, but only smallmouth bass mercury concentrations from the furthest downstream stream reaches (Cascade Dam to Shelburne Dam) were significantly higher than those in Northeastern region studies.

The apparent greater potential for $\mathrm{Hg}(\mathrm{II})$-methylation and mercury bioaccumulation in the lower gradient stream reaches of the Androscoggin River may reflect changes in the type and size of particles deposited to the benthos and the speciation and availability of mercury for $\mathrm{Hg}(\mathrm{II})$-methylation associated with those particles. These findings suggest that an even greater potential for $\mathrm{Hg}(\mathrm{II})$-methylation and mercury bioaccumulation may exist as the river gradient continues to flatten downstream from Shelburne Dam.

\section{Selected References}

\author{
Ainsworth, C.C., Cullinan, V.I., Crecelius, E.A., Wagnon, \\ K.B., and Nielwolny, L.A., 2005, Sample holding time \\ reevaluation: U.S. Environmental Protection Agency \\ EPA/600/R-05/124, 329 p., at http://www.epa.gov/esd/cmb/ \\ research/bs_033cmb06.pdf.
}

Amyot, Marc, Morel, F.M.M., and Ariya, P.A., 2005, Dark oxidation of dissolved and liquid elemental mercury in aquatic environments: Environmental Science and Technology, v. 39, no. 1, p. 110-114.

Avatar Environmental, 2009, Standard operating procedure for fish collection and processing, appendix A of Androscoggin River investigation, chloralkali superfund site, Berlin, N.H.: Avatar Environmental [variously paged].

Bauch, N.J., Chasar, L.C., Scudder, B.C., Moran, P.W., Hitt, K.J., Brigham, M.E., Lutz, M.A., and Wentz, D.A., 2009, Data on mercury in water, bed sediment, and fish from streams across the United States, 1998-2005: U.S. Geological Survey Data Series 307, 33 p., accessed January 8, 2013, at http://pubs.usgs.gov/ds/307/.

Blocksom, Karen, 2004, Development of the New Hampshire Benthic Index of Biotic Integrity, in Neils, David, 2007, $\mathrm{NH}$ benthic index of biotic integrity (B-IBI) for wadeable streams - 2006 threshold modification to account for natural variation: New Hampshire Department of Environmental Services, 39 p., accessed January 8, 2013, at http://des.nh.gov/organization/divisions/water/wmb/ swqa/2006/documents/appendix33.pdf.

Bloom, N.S., Gill, G.A., Cappellino, Steven, Dobbs, Charles, McShea, Larry, Driscoll, Charles, Mason, Robert, and Rudd, John, 1999, Speciation and cycling of mercury in Lavaca Bay, Texas, sediments: Environmental Science and Technology, v. 33, no. 1, p. 7-13. 
Bloom, N.S., Preus, Eve, Katon, Jodie, and Hiltner, Misti, 2003, Selective extractions to assess the biogeochemically relevant fractionation of inorganic mercury in sediments and soils: Analytica Chimica Acta, v. 479, p. 233-248.

Buck, David, and Evers, David, 2011, Standard operating procedure for bird and mammal tissue for contaminant analysis, former chloralkali facility, Berlin, N.H., RFP 80013-040 of Nobis Engineering, quality assurance project plan, ecological investigation, chloralkali facility (former) superfund site, Berlin, New Hampshire: U.S. Environmental Protection Agency Task Order 0013-RI-CO-01BQ, Remedial Action Contract EP-S1-06-03 [variously paged].

Canadian Council of Ministers of the Environment, 1999, Canadian environmental quality guidelines: Canadian Council of Ministers of the Environment, accessed April 16, 2013, at http://st-ts.ccme.ca/.

Degnan, J.R., Clark, S.F., Harte, P.T., and Mack, T.J., 2005, Geology and preliminary hydrogeological characterization of the Cell-House site, Berlin, New Hampshire, 2003-04: U.S. Geological Survey Scientific Investigations Report 2004-5282, 55 p., 1 pl. (Also available at http://pubs.usgs. gov/sir/2004/5282/.)

Degnan, J.R., Teeple, A.P., Johnston, C.M., MarvinDiPasquale, M.C., and Luce, Darryl, 2011, Geophysical bed sediment characterization of the Androscoggin River from the former chloralkali facility superfund site, Berlin, New Hampshire, to the state border with Maine, August 2009: U.S. Geological Survey Scientific Investigations Report 2011-5158, 27 p. (Also available at http://pubs.usgs.gov/ $\operatorname{sir} / 2011 / 5158 /$.

Dennis, I.F., Clair, T.A., Driscoll, C.T., Kamman, Neil, Chalmers, Ann, Shanley, Jamie, Norton, S.A., and Kahl, Steve, 2005, Distribution patterns of mercury in lakes and rivers of northeastern North America: Ecotoxicology, v. 14, p. 113-123.

Dong, Wenming, Liang, Liyuan, Brooks, Scott, Southworth, George, and Gu, Baohua, 2010, Roles of dissolved organic matter in the speciation of mercury and methylmercury in a contaminated ecosystem in Oak Ridge, Tennessee: Environmental Chemistry, v. 7, no. 1, p. 94.

Environmental Services Assistance Team, 2009a, Two species, 96-hour, acute toxicity testing results using pore water samples collected from the Androscoggin River in areas associated with former chloralkali facility in Berlin, N.H.: U.S. Environmental Protection Agency Task Order 26-04, TDF No. 1501, Project Numbers 09090027 and 09090039 , $57 \mathrm{p}$.
Environmental Services Assistance Team, 2009b, Two species, chronic toxicity testing results using surface water samples collected from the Androscoggin River in areas associated with former chloralkali facility in Berlin, N.H.: U.S. Environmental Protection Agency Task Order 26-04, TDF No. 1501, Project Number 09090023, 46 p.

EnviroSystems, 2010a, 20-day Hyalella azteca survival and growth sediment toxicity test, in Nobis Engineering, Inc. Project 80013 DAS-RAC2-030, Toxicity evaluation of freshwater sediment samples: U.S. Environmental Protection Agency Task Order 10-NH-80013-045-TO-01, p. 14.

EnviroSystems, 2010b, 20-day Chironomus dilutes survival and growth sediment toxicity test, in Nobis Engineering, Inc. Project 80013 DAS-RAC2-030, Toxicity evaluation of freshwater sediment samples: U.S. Environmental Protection Agency Task Order 10-NH-80013-045-TO-01, p. 13.

Gerbig, C.A., Kim, C.S., Stegemeier, J.P., Ryan, J.N., and Aiken, G.R., 2011, Formation of nanocolloidal metacinnabar in mercury-DOM-sulfide systems: Environmental Science and Technology, v. 45, no. 21, p. 9180-9187.

Gilmour, C.C., Henry, E.A., and Mitchell, R., 1992, Sulfate stimulation of mercury methylation in freshwater sediments: Environmental Science and Technology, v. 26, p. 22812287.

Hammerschmidt, C.R., and Fitzgerald, W.F., 2006, Methylmercury cycling in sediments on the continental shelf of southern New England: Geochimica et Cosmochimica Acta, v. 70 , no. 4 , p. $918-930$.

Han, S., Obraztsova, A., Pretto, P., Choe, K.Y., Gieskes, J., Deheyn, D.D., and Tebo, B.M., 2007, Biogeochemical factors affecting mercury methylation in sediments of the Venice Lagoon, Italy: Environmental Toxicology and Chemistry, v. 26, no. 4, p. 655-663.

Helsel, D.R., 2005, Nondetects and data analysis-Statistics for censored environmental data: New York, John Wiley \& Sons, Inc., 250 p.

Hill, J.R., O’Driscoll, N.J., and Lean, D.R.S., 2009, Size distribution of methylmercury associated with particulate and dissolved organic matter in freshwaters: Science of the Total Environment, v. 408, no. 2, p. 408-414.

Horvat, Milena, Liang, Lian, and Bloom, N.S., 1993, Comparison of distillation with other current isolation methods for the determination of methyl mercury compounds in low level environment samples - Part II. Water: Analytica Chimica Acta, v. 282, p. 153-168.

Huerta-Diaz, M.A., and Morse, J.W., 1992, Pyritization of trace metals in anoxic marine sediments: Geochimica et Cosmochimica Acta, v. 56, p. 2681-2702. 
Kamman, N.C., Burgess, N.M., Driscoll, C.T., Simonin, H.A., Goodale, Wing, Linehan, Janice, Estabrook, Robert, Hutcheson, Michael, Major, Andrew, Scheuhanmer, A.M., and Scruton, D.A., 2005a, Mercury in freshwater fish of northeast North America-A geographic perspective based on fish tissue monitoring databases: Ecotoxicology, v. 14, nos. 1-2, p. 163-180.

Kamman, N.C., Chalmers, Ann, Clair, T.A., Major, Andrew, Moore, R.B., Norton, S.A., and Shanley, J.B., 2005b, Factors influencing mercury in freshwater surface sediments of northeast North America: Ecotoxicology, v. 14, nos. 1-2, p. 101-111.

Kendall, Carol, Silva, S.R., and Kelly, V.J., 2001, Carbon and nitrogen isotopic compositions of particulate organic matter in four large river systems across the United States: Hydrological Processes, v. 15, no. 7, p. 1301-1346.

Krabbenhoft, D.P., Wiener, J.G., Brumbaugh, W.G., Olson, M.L., DeWild, J.F., and Sabin, T.J., 1999, A national pilot study of mercury contamination of aquatic ecosystems along multiple gradients: U.S. Geological Survey WaterResources Investigations Report 99-4018B [not paged]. (Also available at http://toxics.usgs.gov/pubs/wri99-4018/ Volume2/sectionB/2301_Krabbenhoft/index.html.)

Lambertsson, Lars, and Nilsson, Mats, 2006, Organic material-The primary control on mercury methylation and ambient methyl mercury concentrations in estuarine sediments: Environmental Science and Technology, v. 40, no. 6, p. $1822-1829$.

Lutz, M.A., Brigham, M.E., and Marvin-DiPasquale, Mark, 2008, Procedures for collecting and processing streambed sediment and pore water for analysis of mercury as part of the National Water-Quality Assessment Program: U.S. Geological Survey Open-File Report 2008-1279, 68 p. (Also available at http://pubs.usgs.gov/of/2008/1279/.)

MacDonald, D.D., Ingersoll, C.G., and Berger, T.A., 2000, Development and evaluation of consensus-based sediment quality guidelines for freshwater ecosystems: Archives of Environmental Contamination and Toxicology, v. 39, no. 1, p. 20-31.

Maine Department of Environmental Protection, 2009, Surface Water Ambient Toxics Monitoring Program-2009 final report: Augusta, Maine, Maine Department of Environmental Protection, 168 p., accessed January 14, 2013, at http:/www.maine.gov/dep/water/monitoring/ toxics/swat/2009/2009_SWAT_report_final.pdf.

Marvin-DiPasquale, M.C., and Agee, J.L., 2003, Microbial mercury cycling in sediments of the San Francisco BayDelta: Estuaries, v. 26, p. 1517-1528.
Marvin-DiPasquale, M.C., Agee, J.L., Kakouros, Evangelos, Kieu, L.H., Fleck, J.A., and Alpers, C.N., 2011, The effects of sediment and mercury mobilization in the South Yuba River and Humbug Creek confluence area, Nevada County, California-Concentrations, speciation and environmental fate-Part 2. Laboratory experiments: U.S. Geological Survey Open-File Report 2010-1325B, 53 p., accessed January 14, 2013, at http://pubs.usgs.gov/of/2010/1325B.

Marvin-DiPasquale, M.C., Alpers, C.N., and Fleck, J.A., 2009b, Mercury, methylmercury, and other constituents in sediment and water from seasonal and permanent wetlands in the Cache Creek Settling basin and Yolo bypass, Yolo County, California, 2005-06: U.S. Geological Survey Open-File Report 2009-1182, 69 p., accessed January 14, 2013, at http://pubs.usgs.gov/of/2009/1182/.

Marvin-DiPasquale, M.C., and Cox, M.H., 2007, Legacy mercury in Alviso Slough, south San Francisco Bay, California-Concentration, speciation and mobility: U.S. Geological Survey Open-File Report 2007-1240, 98 p. (Also available at http://pubs.usgs.gov/of/2007/1240/.)

Marvin-DiPasquale, M.C., Hall, B.D., Flanders, J.R., Ladizinski, N., Agee, J.L., Kieu, L.H., and WindhamMyer, Lisamarie, 2006, Ecosystem investigations of benthic methylmercury production-A tin-reduction approach for assessing the inorganic mercury pool available for methylation: Mercury 2006-Eighth International Conference on Mercury as a Global Pollutant, Madison, Wisc., August 6-11, 2006 [abstract].

Marvin-DiPasquale, M.C., Lutz, M.A., Brigham, M.E., Krabbenhoft, D.P., Aiken, G.R., Orem, W.H., and Hall, B.D., 2009a, Mercury cycling in stream ecosystems-2. Benthic methylmercury production and bed sediment-pore water partitioning: Environmental Science and Technology, v. 43 , no. 8 , p. $2726-2732$.

Marvin-DiPasquale, M.C., Lutz, M.A., Krabbenhoft, D.P., Aiken, G.R., Orem, W.H., Hall, B.D., DeWild, J.F., and Brigham, M.E., 2008, Total mercury, methylmercury, methylmercury production potential, and ancillary streambed-sediment and pore water data for selected streams in Oregon, Wisconsin, and Florida, 2003-04: U.S. Geological Survey Data Series 375, 25 p. (Also available at http://pubs.usgs.gov/ds/375/.)

Matthes, W.J., Jr., Sholar, C.J., and George, J.R., 1992, Quality-assurance plan for the analysis of fluvial sediment by laboratories of the U.S. Geological Survey: U.S. Geological Survey Open-File Report 91-467, 37 p. (Also available at http://pubs.usgs.gov/of/1991/0467/report.pdf.)

Morel, F.M.M., Kraepiel, A.M.L., and Amyot, Marc, 1998, The chemical cycle and bioaccumulation of mercury: Annual Review of Ecology and Systematics, v. 29, p. 543566. 
Neils, David, 2007, NH benthic index of biotic integrity (BIBI) for wadeable streams-2006 threshold modification to account for natural variation: New Hampshire Department of Environmental Services, 39 p., accessed January 8, 2013, at http://des.nh.gov/organization/divisions/water/wmb/ swqa/2006/documents/appendix33.pdf.

New Hampshire Department of Environmental Services, 2004, Biomonitoring program protocols: New Hampshire Department of Environmental Services, accessed January 8, 2013, at http://des.nh.gov/organization/divisions/water/ $\mathrm{wmb} /$ biomonitoring/documents/protocols.pdf.

Nobis Engineering, 2009, Appendix B-Fish sampling plan and biological sampling plan, in Quality assurance project plan, ecological investigation, chloralkali facility (former) superfund site, Berlin, New Hampshire: U.S. Environmental Protection Agency Task Order 0013-RI-CO-01BQ, Remedial Action Contract EP-S1-06-03 [variously paged].

Nobis Engineering, 2011, Appendix A-Ecological investigation QAPP sampling SOP reference S-3, Standard operating procedure tree swallow sampling and tissue processing, in Quality assurance project plan, ecological investigation, chloralkali facility (former) superfund site, Berlin, New Hampshire: U.S. Environmental Protection Agency Task Order 0013-RI-CO-01BQ, Remedial Action Contract EPS1-06-03 [variously paged].

Olson, M.L., and DeWild, J.F., 1999, Techniques for the collection and species-specific analysis of low levels of mercury in water, sediment, and biota, in U.S. Geological Survey Toxic Substances Hydrology Program-Proceedings of the technical meeting, Charleston, South Carolina, March 8-12, 1999: U.S. Geological Survey WaterResources Investigations Report 99-4018B, p. 191-200. (Also available at http://toxics.usgs.gov/pubs/wri99-4018/ Volume2/sectionB/2305_Olson/.)

Olund, S.D., DeWild, J.F., Olson, M.L., and Tate, M.T., 2004, Methods for the preparation and analysis of solids and suspended solids for total mercury: U.S. Geological Survey Techniques and Methods, book 5, chap. A8, 23 p. (Also available at http://pubs.usgs.gov/tm/2005/tm5A8/.)

Parker, J.L., and Bloom, N.S., 2005, Preservation and storage techniques for low-level aqueous mercury speciation: Science of the Total Environment, v. 337, nos. 1-3, p. 253-263.

Sample, B.E., Opresko, D.M., and Suter, G.W., 1996, Toxicological benchmarks for wildlife, 1996: Oak Ridge, Tenn., Oak Ridge National Laboratory, Publication ES/ER/TM-86/ R3, 43 p.
Scudder, B.C., Chasar, L.C., Wentz, D.A., Bauch, N.J., Brigham, M.E., Moran, P.W., and Krabbenhoft, D.P., 2009, Mercury in fish, bed sediment, water from streams across the United States, 1998-2005: U.S. Geological Survey Scientific Investigations Report 2009-5109, 74 p. (Also available at http://pubs.usgs.gov/sir/2009/5109/.)

Shanley, J.B., Kamman, N.C., Clair, T.A., and Chalmers, A.T., 2005, Physical controls on total and methylmercury concentrations in streams and lakes of northeastern USA: Ecotoxicology, v. 14, p. 125-134.

Shelton, L.R., and Capel, P.D., 1994, Guidelines for collecting and processing samples of stream bed sediment for analysis of trace elements and organic contaminants for the National Water-Quality Assessment Program: U.S. Geological Survey Open-File Report 94-458, 20 p. (Also available at http://water.usgs.gov/nawqa/pnsp/pubs/ofr94-458/.)

Slowey, A.J., 2010, Rate of formation and dissolution of mercury sulfide nanoparticles-The dual role of natural organic matter: Geochimica et Cosmochimica Acta, v. 74, p. 4693-4708.

Sunderland, E.M., Gobas, F.A.P.C., Branfireun, B.A., and Heyes, Andrew, 2006, Environmental controls on the speciation and distribution of mercury in coastal sediments: Marine Chemistry, v. 102, p. 111-123.

U.S. Environmental Protection Agency, 1995, Great Lakes water quality initiative technical support document for wildlife criteria: U.S. Environmental Protection Agency 820-B95-009, 53 p.

U.S. Environmental Protection Agency, 2000, Methods for measuring the toxicity and bioaccumulation of sedimentassociated contaminants with freshwater invertebrates (2d ed.): U.S. Environmental Protection Agency EPA/600R-99/064, 192 p.

U.S. Environmental Protection Agency, 2001a, Acute (96hour) reference toxicity test methods for Hyalella azteca and Chironomous tentans: U.S. Environmental Protection Agency, Biology Section, Standard Operating Procedure [variously paged].

U.S. Environmental Protection Agency, 2001b, Appendix to method 1631-Total mercury in tissue, sludge, sediment, and soil by acid digestion and $\mathrm{BrCl}$ oxidation: U.S. Environmental Protection Agency EPA-821-R-01-013, 13 p. (Also available at http://www.tekran.com/files/EPA_1631 Appendix_for_Solids.pdf.)

U.S. Environmental Protection Agency, 2001c, Water quality criterion for protection of human health-Methylmercury: U.S. Environmental Protection Agency Technical Report EPA/823/R-01/001 [variously paged]. 
U.S. Environmental Protection Agency, 2002, Method 1631, revision E-Mercury in water by oxidation, purge and trap, and cold vapor atomic fluorescence spectrometry: U.S. Environmental Protection Agency EPA-821-R-02-019, 38 p. (Also available at http://water.epa.gov/scitech/ methods/cwa/metals/mercury/index.cfm.)

U.S. Environmental Protection Agency, 2005, National priorities list for uncontrolled hazardous waste sites: Federal Register, v. 70, no. 177, September 14, 2005, p. 54286-54293, accessed January 10, 2013, at http://www.gpo.gov/fdsys/ pkg/FR-2005-09-14/pdf/05-18235.pdf.

U.S. Environmental Protection Agency, 2008a, Chronic toxicity method for Ceriodaphnia dubia (revision 5.0): U.S. Environmental Protection Agency, Biology Section Standard Operating Procedure, Office of Environmental Measurements and Evaluation, U.S. Environmental Protection Agency, Region 1.

U.S. Environmental Protection Agency, 2008b, Chronic toxicity method for Pimephales promelas (revision 6.0): U.S. Environmental Protection Agency, Biology Section Standard Operating Procedure, Office of Environmental Measurements and Evaluation, U.S. Environmental Protection Agency, Region 1.

U.S. Environmental Protection Agency, 2010, Guidance for implementing the January 2001 methylmercury water quality criterion: Washington D.C., Office of Water, EPA823-R-10-001, 209 p., accessed February 4, 2013, at http://water.epa.gov/scitech/swguidance/standards/criteria/ aqlife/methylmercury/upload/mercury2010.pdf.
U.S. Geological Survey, 2005, National field manual for the collection of water-quality data: U.S. Geological Survey Techniques of Water-Resources Investigations, book 9, $46 \mathrm{p}$.

Weston Solutions, Inc., 2005, Site Investigation ReportFormer Chlor Alkali Facility below Saw Mill Dam: Berlin, N.H., February 10, 2004, 203 p.

Wilde, F.D., 2008, Field measurements: U.S. Geological Survey Techniques of Water-Resources Investigations, book 9, chap. A6, accessed January 15, 2013, at http://pubs.water.usgs.gov/twri9A6/.

Xianchao, Y., Chandrasekhar, T.M., and Tate, K., 2005, Analysis of methylmercury in sediment and tissue by $\mathrm{KOH} / \mathrm{CH} 3 \mathrm{OH}$ digestion followed by aqueous phase ethylation: Florida Department of Environmental Protection HG-003-2.2.

Yeardley, R.B., Jr., Lazorchak, J.M., and Paulsen, S.G., 1998, Elemental fish tissue contamination in northeastern U.S. lakes-Evaluation of an approach to regional assessment: Environmental Toxicology and Chemistry, v. 17, no. 9, p. $1875-1884$.

Zimmerman, M.J., Massey, A.J., and Campo, K.W., 2005, Pushpoint sampling for defining spatial and temporal variations in contaminant concentrations in sediment pore water near the ground-water/surface water interface: U.S. Geological Survey Scientific Investigations Report 2005-5036, 70 p. (Also available at http://pubs.usgs.gov/ $\operatorname{sir} / 2005 / 5036 /$. 
THIS PAGE INTENTIONALLY LEFT BLANK 
Tables 2, 4, 5, and 6 


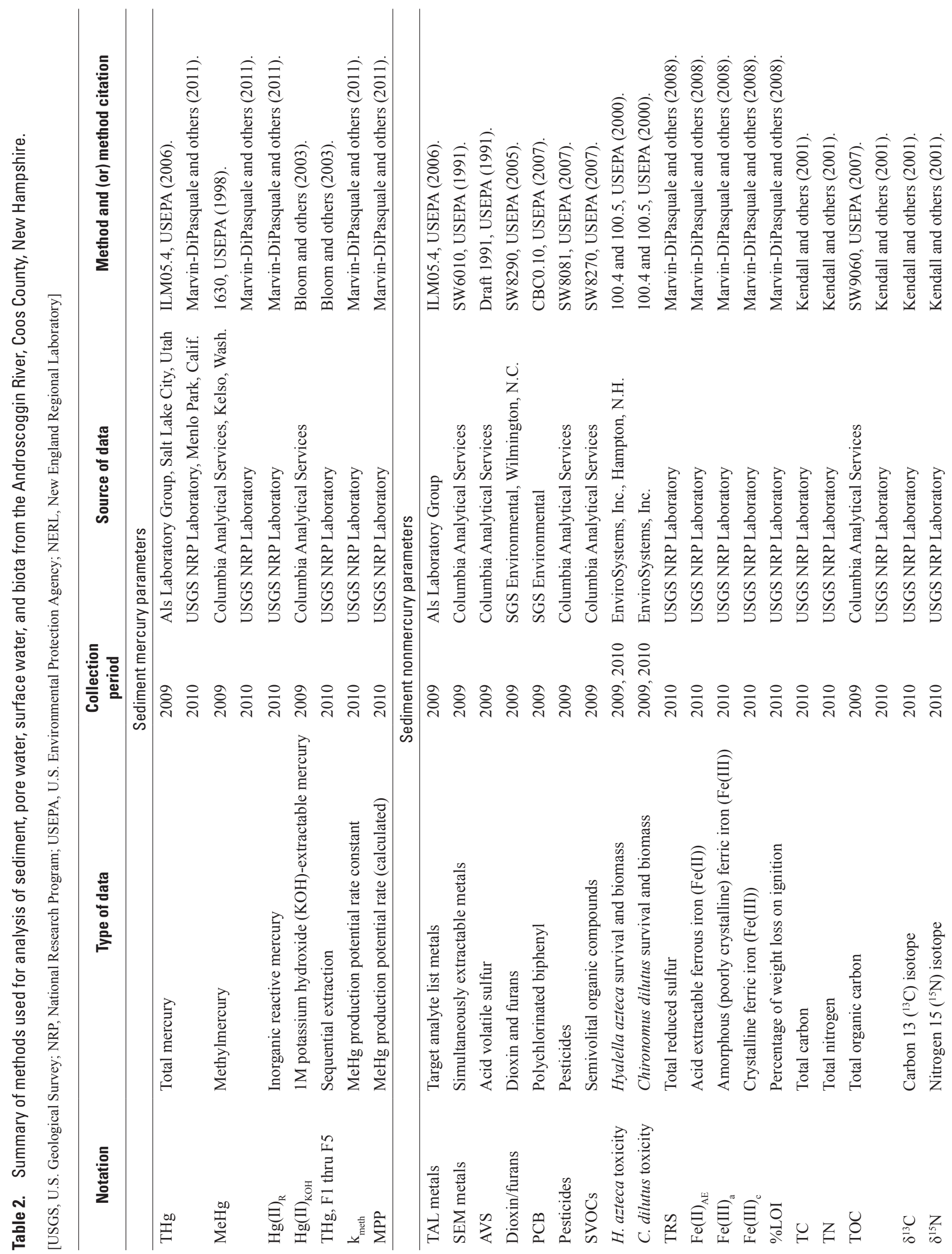




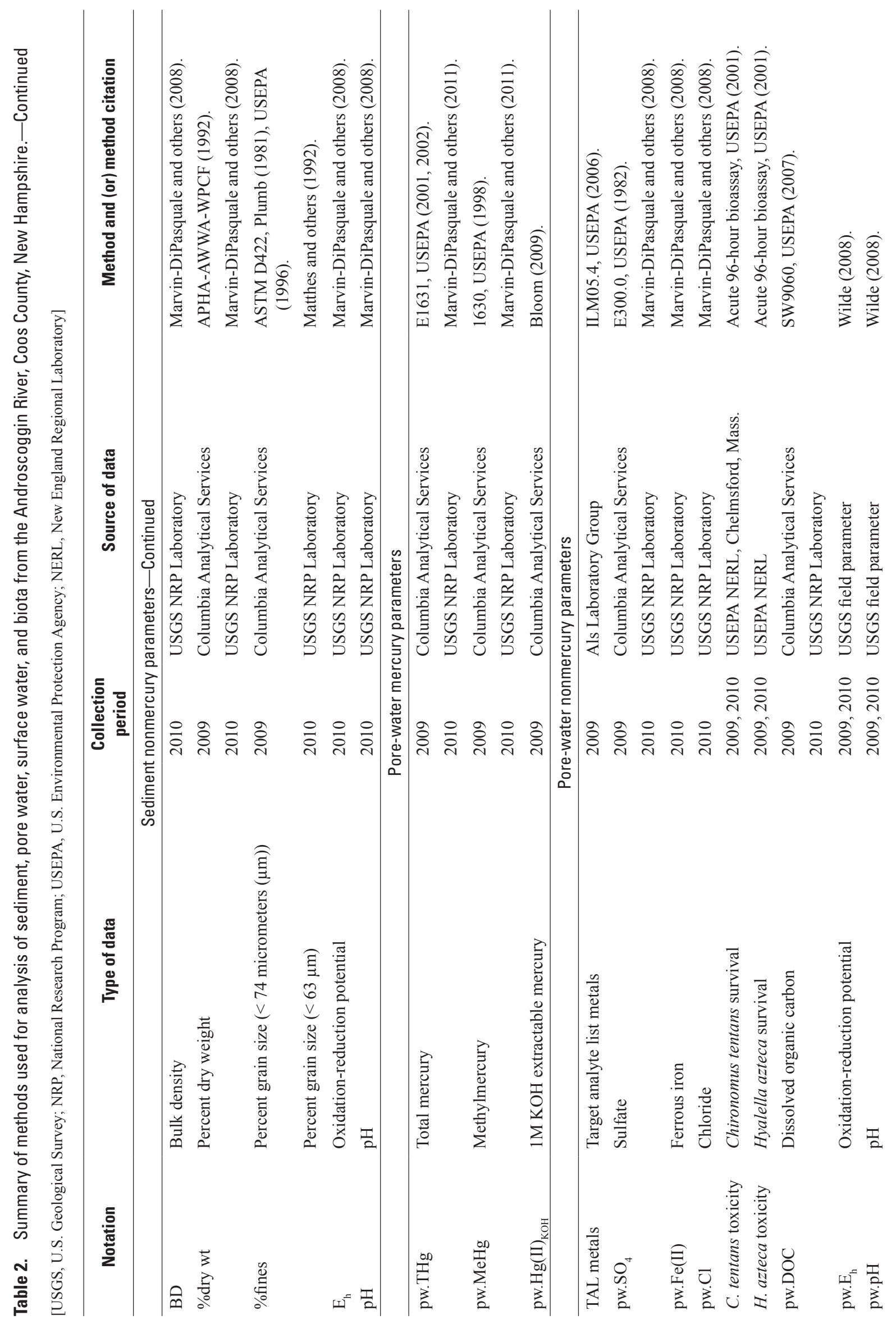




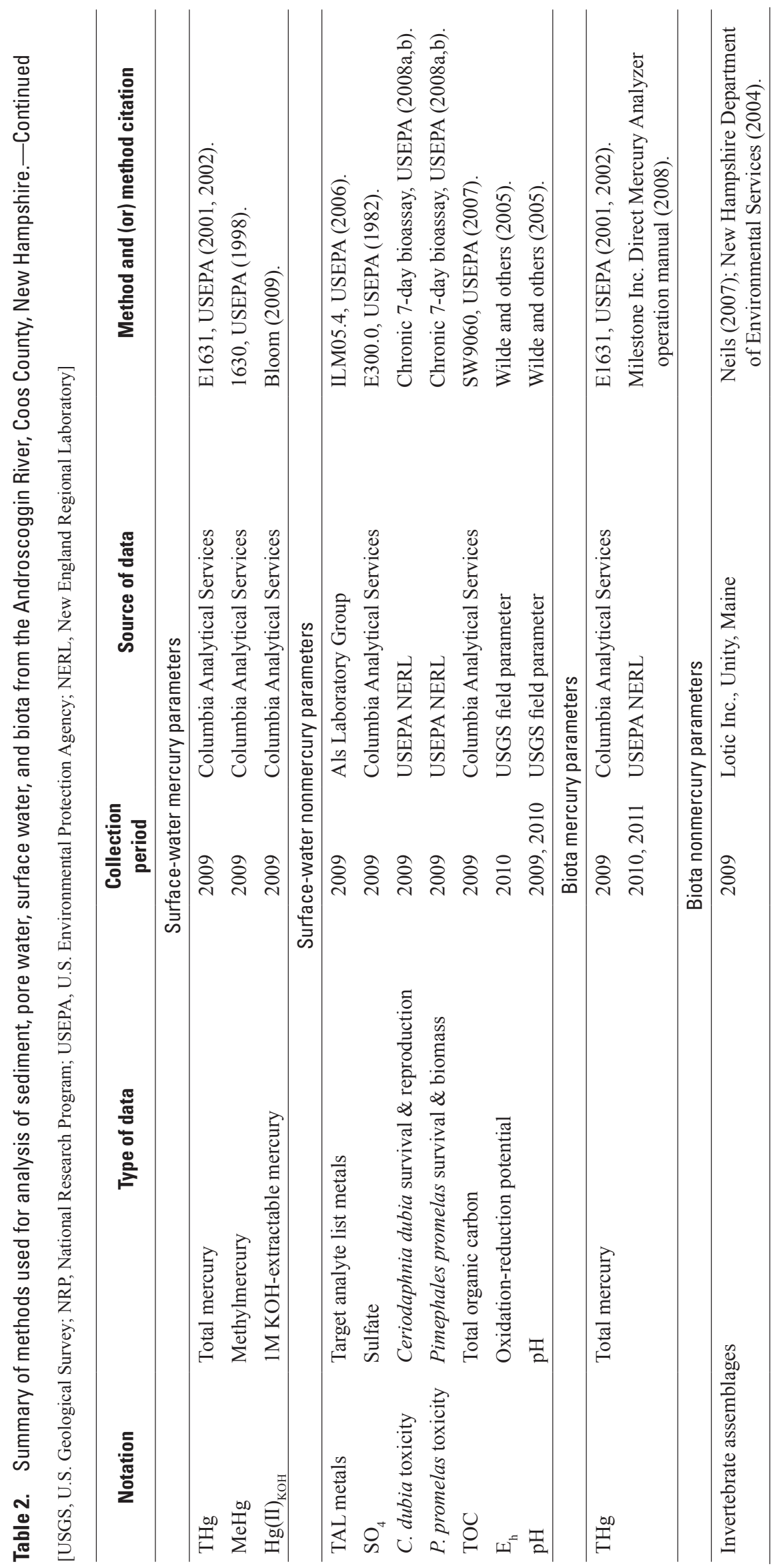


Table 4
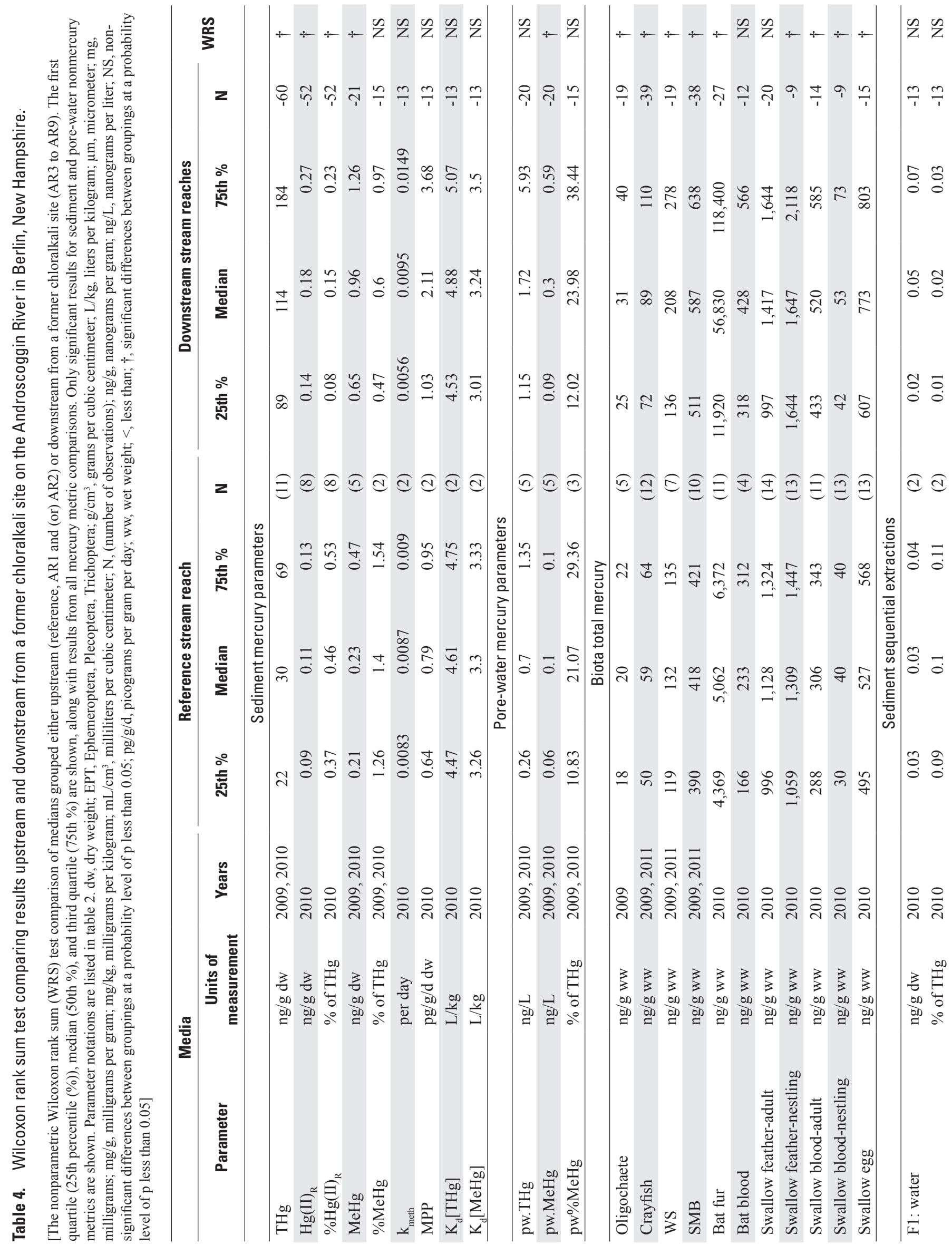

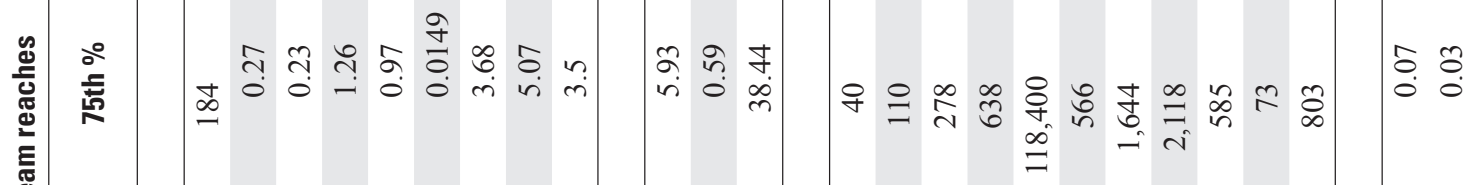

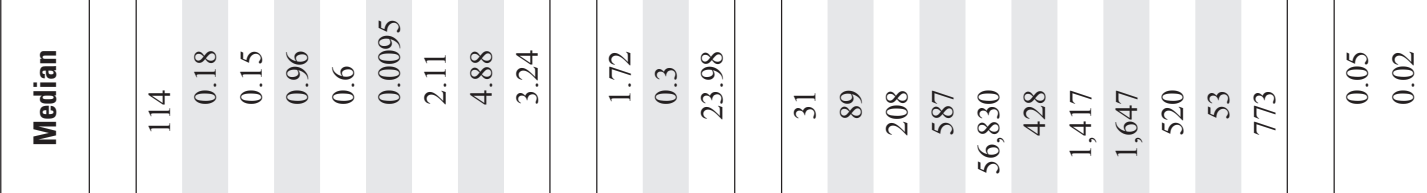

䓂

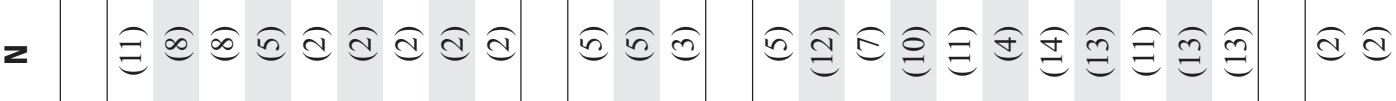

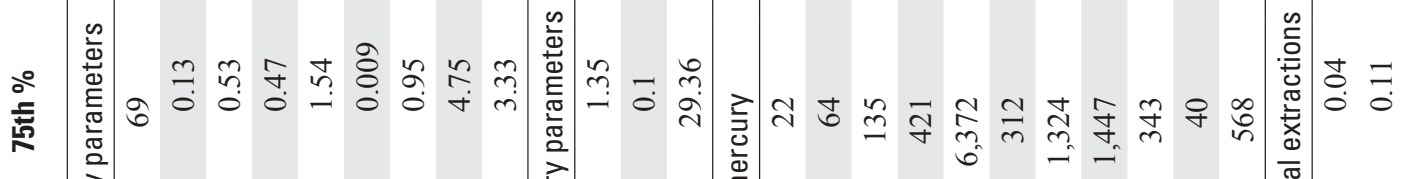

言

$\stackrel{\frac{\pi}{2}}{\frac{\pi}{2}}$

空

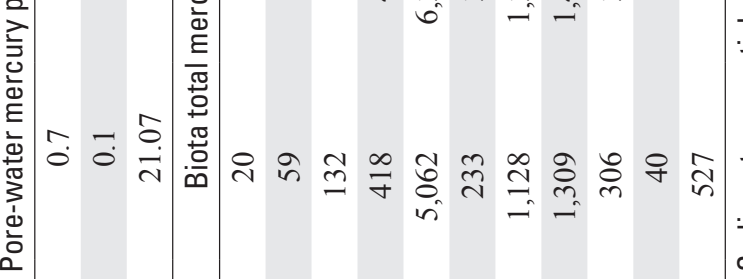

竞

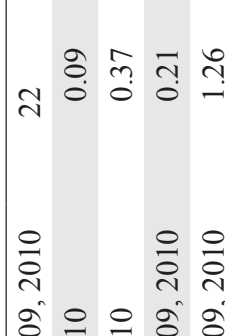

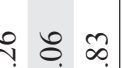

œ

离

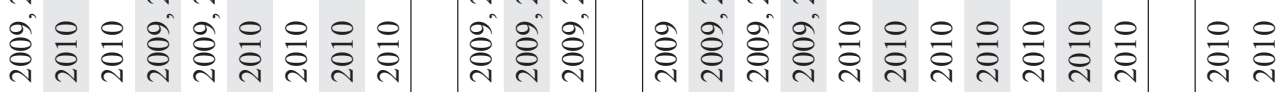

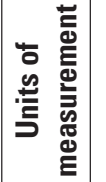

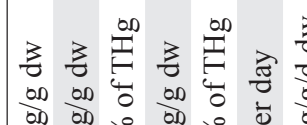

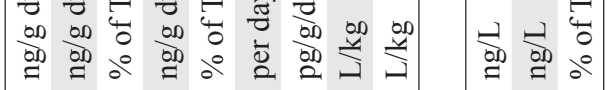

$3 \sum_{3}^{3} \sum_{3}^{3}$

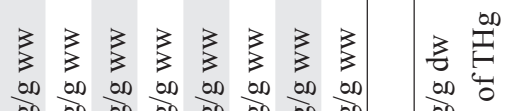

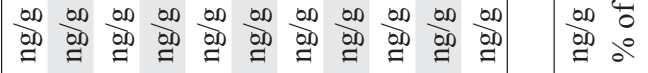

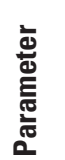

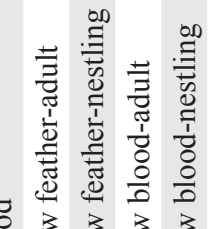

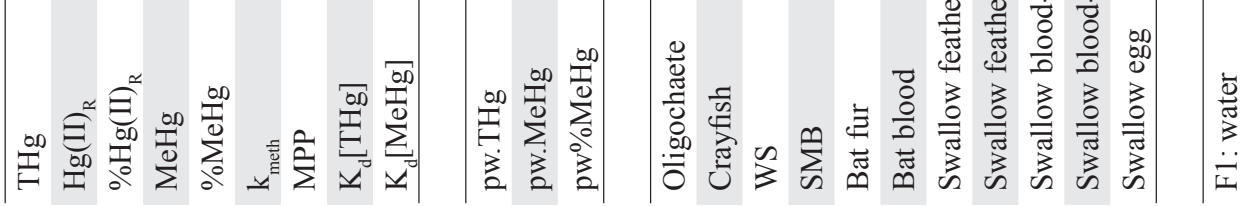



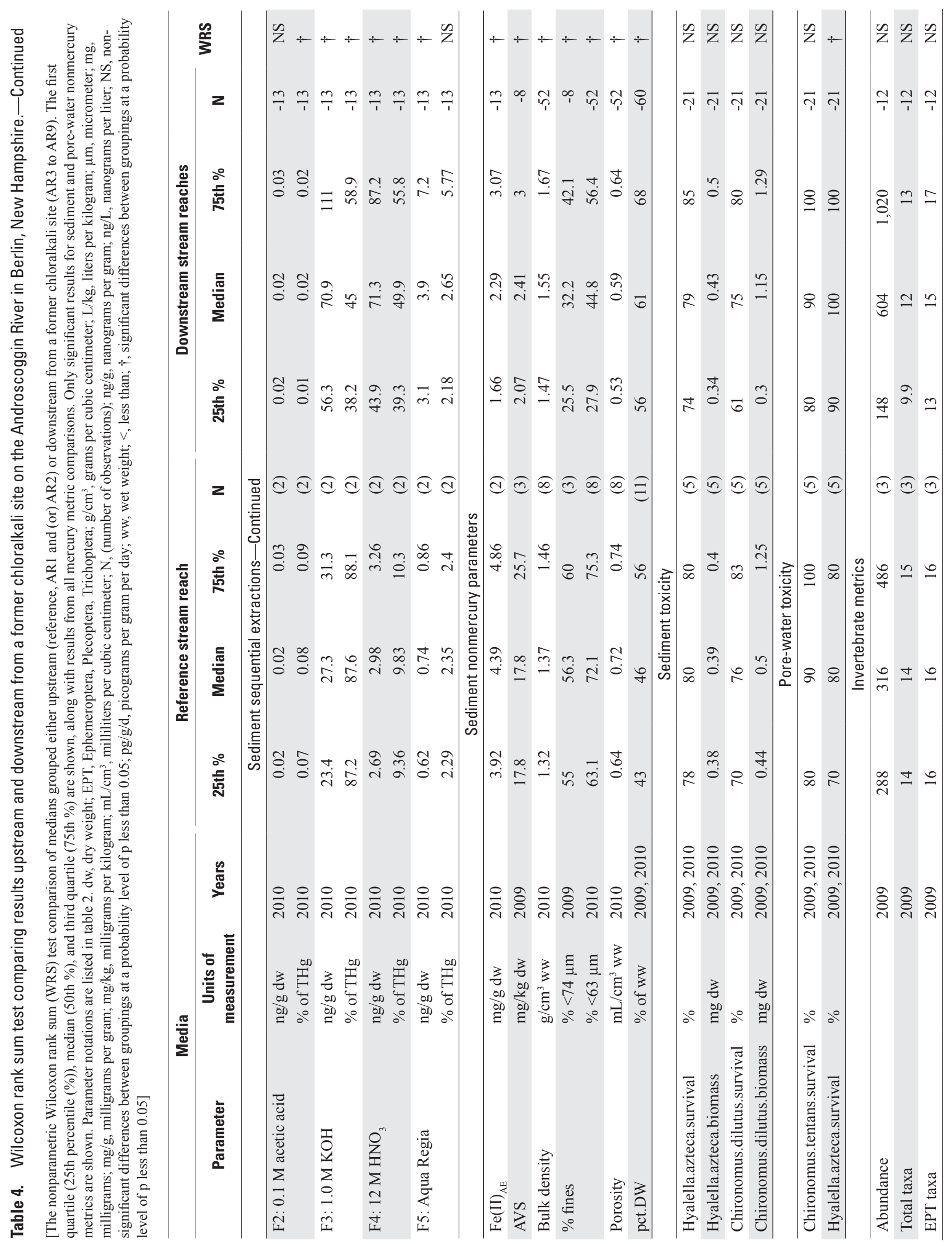
Table 5

47

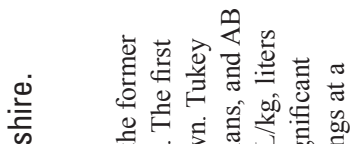

कू छ

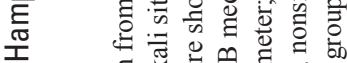

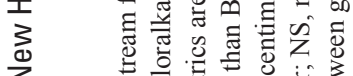

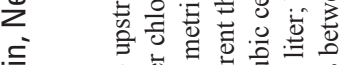

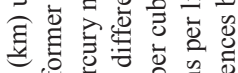

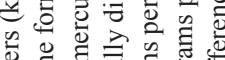

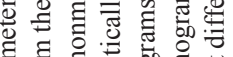

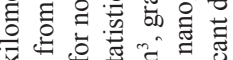

可

焉

a

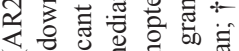

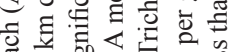

巴㔾

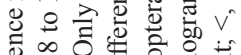

计

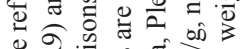

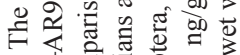

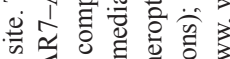

牙.

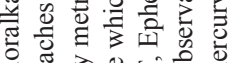

긍

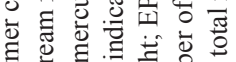

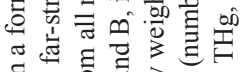

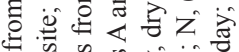

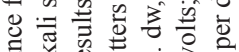

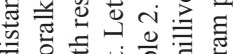

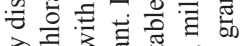

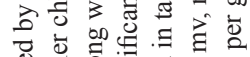

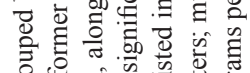

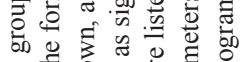

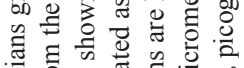

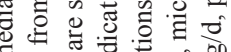

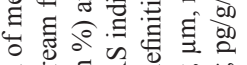

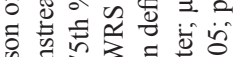

की है

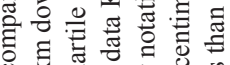

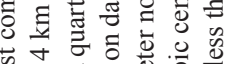

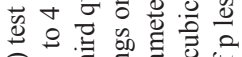

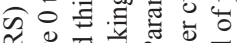

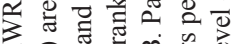

00

원의

क

넝

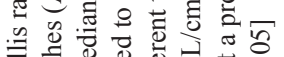

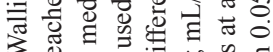

1 0 on

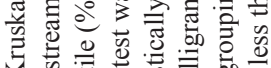

击

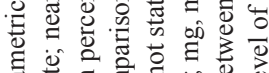

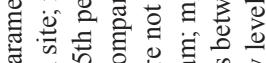

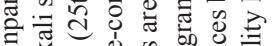

要

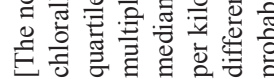
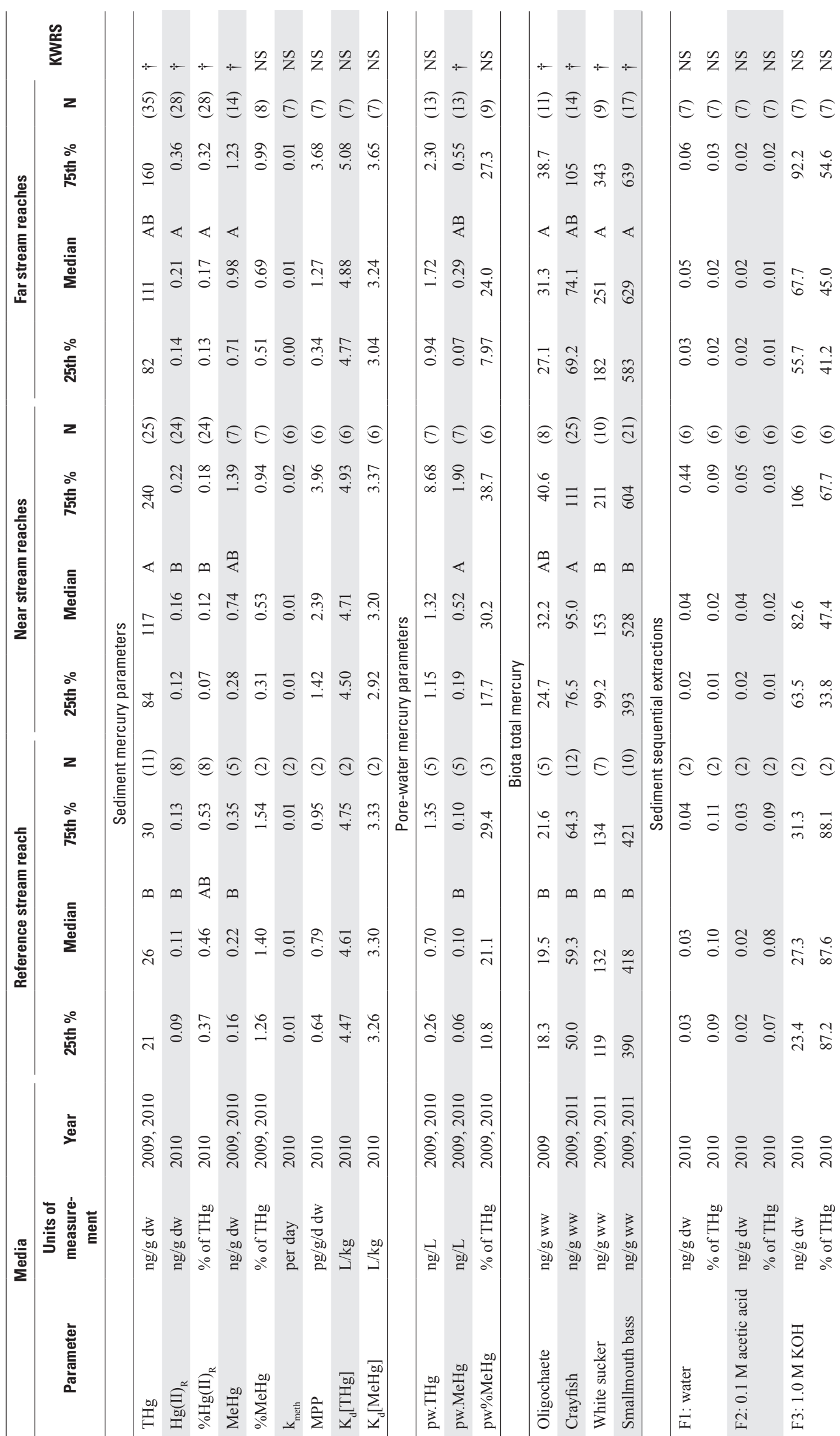

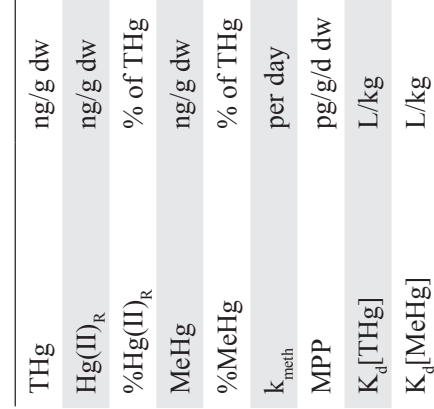

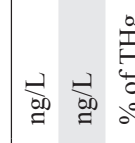

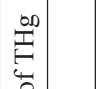

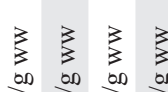

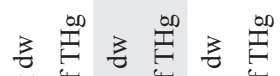

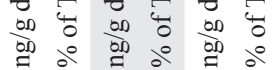

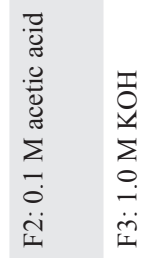




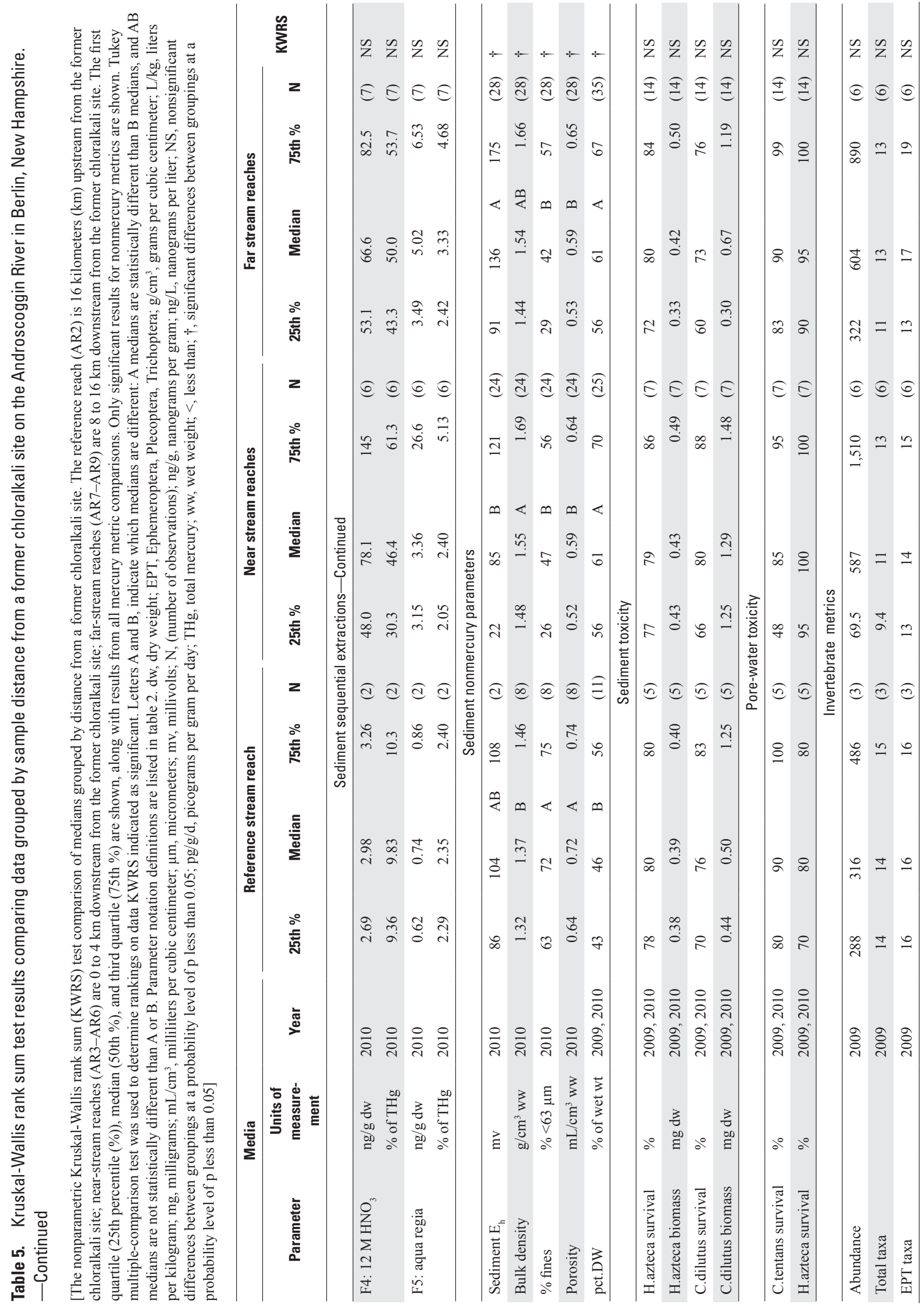


Table 6. Sequential extraction results for surface sediment, Androscoggin River, Coos County, New Hampshire.

[Surface sediment encompasses 0- to 10-centimeter (cm) interval. See table 3 for details on the specific fraction number (F\#) and associated dominant mercury species extracted. THg, total mercury; ng/g, nanograms per gram; --, no data]

\begin{tabular}{|c|c|c|c|c|}
\hline \multirow[t]{2}{*}{ F\# } & \multicolumn{3}{|c|}{$\begin{array}{c}\mathrm{THg}, \\
\text { in ng/g dry weight }\end{array}$} & \multirow{2}{*}{$\begin{array}{c}\text { THg, average } \\
\text { in percent }\end{array}$} \\
\hline & Replicate 1 & Replicate 2 & Average & \\
\hline \multicolumn{5}{|c|}{ AR2-4 } \\
\hline $\mathrm{F} 1$ & 0.02 & 0.07 & 0.05 & 0.12 \\
\hline $\mathrm{F} 2$ & 0.03 & 0.02 & 0.03 & 0.07 \\
\hline F3 & 34.2 & 36.2 & 35.2 & 88.6 \\
\hline F4 & 3.79 & 3.29 & 3.54 & 8.9 \\
\hline F5 & 0.96 & 1 & 0.98 & 2.46 \\
\hline Total & 39 & 40.5 & 39.8 & 100 \\
\hline \multicolumn{5}{|c|}{ AR2-5 } \\
\hline $\mathrm{F} 1$ & 0.02 & -- & 0.02 & 0.08 \\
\hline $\mathrm{F} 2$ & 0.02 & -- & 0.02 & 0.09 \\
\hline F3 & 19.4 & -- & 19.4 & 86.8 \\
\hline $\mathrm{F} 4$ & 2.41 & -- & 2.41 & 10.8 \\
\hline F5 & 0.5 & -- & 0.5 & 2.24 \\
\hline Total & 22.4 & -- & 22.4 & 100 \\
\hline \multicolumn{5}{|c|}{ AR4-1 } \\
\hline F1 & 0.83 & 0.96 & 0.89 & 0.11 \\
\hline $\mathrm{F} 2$ & 0.03 & 0.07 & 0.05 & 0.01 \\
\hline F3 & 62.8 & 57.6 & 60.2 & 7.64 \\
\hline $\mathrm{F} 4$ & 338 & 1,020 & 680 & 86.3 \\
\hline F5 & 37.8 & 56.4 & 47.1 & 5.97 \\
\hline Total & 439 & 1,140 & 788 & 100 \\
\hline \multicolumn{5}{|c|}{ AR4-2 } \\
\hline $\mathrm{F} 1$ & 0.56 & 0.59 & 0.58 & 0.44 \\
\hline $\mathrm{F} 2$ & 0.02 & 0.02 & 0.02 & 0.02 \\
\hline F3 & 35.2 & 47.9 & 41.6 & 31.9 \\
\hline $\mathrm{F} 4$ & 78.5 & 91.4 & 84.9 & 65.1 \\
\hline F5 & 3.66 & 3.17 & 3.41 & 2.62 \\
\hline Total & 118 & 143 & 130 & 100 \\
\hline \multicolumn{5}{|c|}{ AR5-1 } \\
\hline $\mathrm{F} 1$ & 0.02 & -- & 0.02 & 0.01 \\
\hline $\mathrm{F} 2$ & 0.03 & -- & 0.03 & 0.02 \\
\hline F3 & 111 & -- & 111 & 71.9 \\
\hline F4 & 40.2 & -- & 40.2 & 26.1 \\
\hline F5 & 3.1 & -- & 3.1 & 2.01 \\
\hline Total & 154 & -- & 154 & 100 \\
\hline \multicolumn{5}{|c|}{ AR5-2 } \\
\hline F1 & 0.05 & -- & 0.05 & 0.01 \\
\hline $\mathrm{F} 2$ & 0.1 & -- & 0.1 & 0.03 \\
\hline F3 & 131 & -- & 131 & 39.7 \\
\hline F4 & 165 & -- & 165 & 49.9 \\
\hline F5 & 34.3 & -- & 34.3 & 10.4 \\
\hline Total & 331 & -- & 331 & 100 \\
\hline
\end{tabular}


Table 6. Sequential extraction results for surface sediment, Androscoggin River, Coos County, New Hampshire.

\section{-Continued}

[Surface sediment encompasses 0- to 10-centimeter $(\mathrm{cm})$ interval. See table 3 for details on the specific fraction number (F\#) and associated dominant mercury species extracted. THg, total mercury; ng/g, nanograms per gram; --, no data]

\begin{tabular}{|c|c|c|c|c|}
\hline \multirow[t]{2}{*}{ F\# } & \multicolumn{3}{|c|}{$\begin{array}{c}\mathrm{THg}, \\
\text { in ng/g dry weight }\end{array}$} & \multirow{2}{*}{$\begin{array}{c}\text { THg, average } \\
\text { in percent }\end{array}$} \\
\hline & Replicate 1 & Replicate 2 & Average & \\
\hline \multicolumn{5}{|c|}{ AR6-2 } \\
\hline $\mathrm{F} 1$ & 0.03 & -- & 0.03 & 0.03 \\
\hline $\mathrm{F} 2$ & 0.04 & -- & 0.04 & 0.05 \\
\hline F3 & 73.5 & -- & 73.5 & 77.6 \\
\hline F4 & 19.1 & -- & 19.1 & 20.2 \\
\hline F5 & 2.06 & -- & 2.06 & 2.18 \\
\hline Total & 94.7 & -- & 94.7 & 100 \\
\hline \multicolumn{5}{|c|}{ AR6-3 } \\
\hline F1 & 0.01 & -- & 0.01 & 0.01 \\
\hline $\mathrm{F} 2$ & 0.01 & -- & 0.01 & 0.01 \\
\hline F3 & 91.8 & -- & 91.8 & 55.2 \\
\hline F4 & 71.3 & -- & 71.3 & 42.8 \\
\hline F5 & 3.3 & -- & 3.3 & 1.98 \\
\hline Total & 166 & -- & 166 & 100 \\
\hline \multicolumn{5}{|c|}{ AR7-1 } \\
\hline $\mathrm{F} 1$ & 0.07 & -- & 0.07 & 0.05 \\
\hline $\mathrm{F} 2$ & 0.02 & -- & 0.02 & 0.01 \\
\hline F3 & 56.3 & -- & 56.3 & 38.2 \\
\hline $\mathrm{F} 4$ & 87.2 & -- & 87.2 & 59.1 \\
\hline F5 & 3.9 & -- & 3.9 & 2.65 \\
\hline Total & 147 & -- & 147 & 100 \\
\hline \multicolumn{5}{|c|}{ AR7-2 } \\
\hline $\mathrm{F} 1$ & 0.05 & -- & 0.05 & 0.03 \\
\hline $\mathrm{F} 2$ & 0.02 & -- & 0.02 & 0.01 \\
\hline F3 & 114 & -- & 113.5 & 69.5 \\
\hline F4 & 43.8 & -- & 43.8 & 26.8 \\
\hline F5 & 5.85 & -- & 5.85 & 3.58 \\
\hline Total & 163 & -- & 163 & 100 \\
\hline \multicolumn{5}{|c|}{ AR8-4 } \\
\hline $\mathrm{F} 1$ & 0.02 & -- & 0.02 & 0.01 \\
\hline $\mathrm{F} 2$ & 0.03 & -- & 0.03 & 0.02 \\
\hline F3 & 70.9 & -- & 70.9 & 50.4 \\
\hline F4 & 66.6 & -- & 66.6 & 47.4 \\
\hline F5 & 3.08 & -- & 3.08 & 2.19 \\
\hline Total & 141 & -- & 141 & 100 \\
\hline \multicolumn{5}{|c|}{ AR8-5 } \\
\hline F1 & 0.03 & -- & 0.03 & 0.02 \\
\hline $\mathrm{F} 2$ & 0.02 & -- & 0.02 & 0.02 \\
\hline F3 & 55.1 & -- & 55.1 & 44.1 \\
\hline F4 & 62.4 & -- & 62.4 & 50 \\
\hline F5 & 7.2 & -- & 7.2 & 5.77 \\
\hline Total & 125 & -- & 125 & 100 \\
\hline
\end{tabular}


Table 6. Sequential extraction results for surface sediment, Androscoggin River, Coos County, New Hampshire. -Continued

[Surface sediment encompasses 0- to 10-centimeter (cm) interval. See table 3 for details on the specific fraction number (F\#) and associated dominant mercury species extracted. THg, total mercury; ng/g, nanograms per gram; --, no data]

\begin{tabular}{|c|c|c|c|c|}
\hline \multirow[t]{2}{*}{ F\# } & \multicolumn{3}{|c|}{$\begin{array}{c}\text { THg, } \\
\text { in ng/g dry weight }\end{array}$} & \multirow{2}{*}{$\begin{array}{l}\text { THg, average, } \\
\text { in percent }\end{array}$} \\
\hline & Replicate 1 & Replicate 2 & Average & \\
\hline \multicolumn{5}{|c|}{ AR9-5 } \\
\hline $\mathrm{F} 1$ & 0.01 & -- & 0.01 & 0.02 \\
\hline $\mathrm{F} 2$ & 0.02 & -- & 0.02 & 0.05 \\
\hline $\mathrm{F} 3$ & 28.7 & -- & 28.7 & 58.9 \\
\hline $\mathrm{F} 4$ & 19.2 & -- & 19.2 & 39.3 \\
\hline F5 & 0.86 & -- & 0.86 & 1.77 \\
\hline Total & 48.8 & -- & 48.8 & 100 \\
\hline \multicolumn{5}{|c|}{ AR9-6 } \\
\hline $\mathrm{F} 1$ & 0.05 & -- & 0.05 & 0.03 \\
\hline $\mathrm{F} 2$ & 0.02 & -- & 0.02 & 0.01 \\
\hline F3 & 67.7 & -- & 67.7 & 45 \\
\hline $\mathrm{F} 4$ & 77.8 & -- & 77.8 & 51.7 \\
\hline F5 & 5.02 & -- & 5.02 & 3.33 \\
\hline Total & 151 & -- & 151 & 100 \\
\hline \multicolumn{5}{|c|}{ AR9-7 } \\
\hline $\mathrm{F} 1$ & 0.1 & -- & 0.1 & 0.02 \\
\hline $\mathrm{F} 2$ & 0.02 & -- & 0.02 & 0 \\
\hline F3 & 120 & -- & 119.8 & 24.2 \\
\hline $\mathrm{F} 4$ & 276 & -- & 276 & 55.8 \\
\hline F5 & 98.7 & -- & 98.7 & 20 \\
\hline Total & 494 & -- & 494 & 100 \\
\hline
\end{tabular}


THIS PAGE INTENTIONALLY LEFT BLANK 


\section{Appendix 1. Quality Assurance and Control at the U.S. Geological Survey Laboratory in Menlo Park, California}

\section{Tables}

1-1. Holding times and preservation used for sediment samples collected from the Androscoggin River, Coos County, New Hampshire, August 23-27, 2010

1-2. Method blanks and method detection limits used for the study of the Androscoggin River, Coos County, New Hampshire

1-3. Laboratory analytical replicate results for sediment and pore-water samples from the Androscoggin River, Coos County, New Hampshire, collected August 23-27, 2010

1-4. Matrix spike results for sediment and pore-water samples collected from the Androscoggin River, Coos County, New Hampshire, August 23-27, 2010

1-5. Certified reference material recovery results for the study of the Androscoggin River, Coos County, New Hampshire 


\section{Appendix 1. Quality Assurance and Control at the U.S. Geological Survey Laboratory in Menlo Park, California}

Quality assurance (QA) and quality control (QC) results for all parameters assayed by the U.S. Geological Survey (USGS) Western Region Research Laboratory in Menlo Park, Calif., are listed below.

\section{Holding Times}

All assays were conducted within the prescribed holding times, as established by either the U.S. Environmental Protection Agency (USEPA), the U.S. Geological Survey (USGS), or peer-reviewed studies from the literature (Horvat and others, 1993; Parker and Bloom, 2005; table 1-1). In the case of studies published in the literature, the USGS laboratory takes a conservative prescribed holding time approach by setting sample holding limits lower than the published study results.

\section{Blanks}

Method blanks were run to assess contamination introduced in the laboratory. In most cases, values from the method blanks were below our method detection limit (table 1-2), indicating that the methods and equipment used were free of (or did not introduce) contamination. The exceptions were for pore-water dissolved organic carbon (pw.DOC) and chloride (pw.Cl) where small amounts of the analyte were detected.

\section{Laboratory Replicates}

Laboratory analytical replicates represent multiple samples taken from the same container of site-specific sediment as a measure of both sample homogeneity and laboratory reproducibility. At least one analytical replicate was analyzed for each sediment and pore-water parameter; the results are listed in table 1-3.

\section{Matrix Spike Samples}

Matrix spike percent recoveries were evaluated to determine acceptable accuracy based on method-specific percent recoveries, which are generally set to be 75 - to 125 -percent recovery for the laboratory's control limit (table 1-4). Typically when spikes are reported below this accepted range, they indicate a low bias, and when reported above this range, they indicate a high bias. However, if the spike concentration was low compared with the sample concentration, a poor recovery is not in itself indicative of a QC problem. Further, not all sediment parameters are amenable to matrix spikes. For example, the addition of mercuric chloride to sediment quickly partitions itself between tin-reducible and nonreducible pools and thus cannot be used as a reliable matrix spike for the reactive divalent mercury $\left(\mathrm{Hg}(\mathrm{II})_{\mathrm{R}}\right)$ assay. Similarly, there is no commercially available material that can mimic the operationally defined amorphous ferric iron $\left(\mathrm{Fe}(\mathrm{III})_{\mathrm{a}}\right)$ sediment pool, and thus the $\mathrm{Fe}(\mathrm{III})_{\mathrm{a}}$ assay is not subject to a matrix spike assay.

\section{Certified Reference Material}

Certified reference material (CRM) is available for only a limited number of the analytes assayed in the study of the Androscoggin River, specifically for sediment total mercury ( $\mathrm{THg}$ ) and methylmercury (MeHg). Like matrix spikes, CRM recoveries were evaluated to determine acceptable accuracy based on method-specific percent recoveries, which are generally set to be 75 to 125 percent for the laboratory's control limit. CRM recovery results for $\mathrm{THg}$ and $\mathrm{MeHg}$ are listed in table $1-5$. 


\section{Appendix 2. Surface-Water, Pore-Water, Sediment, Invertebrate, and Biota Data}

Data in the following tables are for whole (unsieved) streambed-sediment, filtered porewater, and filtered and unfiltered surface-water samples. Pore-water samples were collected directly from the streambed using a push-point sampler and peristaltic pump.

\section{Tables}

2-1. Sampling dates, and site descriptions for sediment, water, and benthic invertebrate samples from the Androscoggin River, Coos County, New Hampshire

2-2. Parameters used in the analysis of surface-water samples from the Androscoggin River, Coos County, New Hampshire

2-3. Concentrations of metals in streambed-sediment samples from the Androscoggin River, Coos County, New Hampshire

2-4. Parameters used in the analysis of pore-water samples from the Androscoggin River, Coos County, New Hampshire

2-5. Concentrations of metals in filtered and unfiltered pore-water samples from the Androscoggin River, Coos County, New Hampshire

2-6. Parameters used in the analysis of streambed-sediment samples from the Androscoggin River, Coos County, New Hampshire

2-7. Concentrations of metals in streambed-sediment samples from the Androscoggin River, Coos County, New Hampshire

2-8. Concentrations of acid volatile sulfide and simultaneously extractable metals in streambed-sediment samples from the Androscoggin River, Coos County, New Hampshire

2-9. Concentrations of pesticides in streambed-sediment samples from the Androscoggin River, Coos County, New Hampshire

2-10. Concentrations of semivolatile organic compounds in streambed-sediment samples from the Androscoggin River, Coos County, New Hampshire

2-11. Concentrations of polychlorinated biphenyl compounds in streambed-sediment samples from the Androscoggin River, Coos County, New Hampshire

2-12. Concentrations of dioxin and furan compounds in streambed-sediment samples from the Androscoggin River, Coos County, New Hampshire

2-13. Results of 7-day toxicity tests for cladoceran and fathead minnow exposed to surface water from the Androscoggin River, Coos County, New Hampshire

2-14. Survival rate from 96-hour toxicity tests for amphipod Hyalella azteca and midge Chironomus tentans exposed to pore-water from the Androscoggin River, Coos County, New Hampshire

2-15. Results of 28-day toxicity tests for amphipod Hyalella azteca and 20-day toxicity tests for midge Chironomus dilutus exposed to sediments from the Androscoggin River, Coos County, New Hampshire

2-16. Concentrations of total mercury in biota in the Androscoggin River, Coos County, New Hampshire

2-17. New Hampshire Department of Environmental Services benthic index of biotic integrity for the Androscoggin River, Coos County, New Hampshire 
2-18. Benthic invertebrates from the Androscoggin River downstream from Pontook Dam, Coos County, New Hampshire

2-19. Benthic invertebrates from the Androscoggin River downstream from Sawmill Dam, Coos County, New Hampshire

2-20. Benthic invertebrates from the Androscoggin River downstream from Riverside Dam, Coos County, New Hampshire

2-21. Benthic invertebrates from the Androscoggin River downstream from Brown Dam, Coos County, New Hampshire

2-22. Benthic invertebrates from the Androscoggin River downstream from Gorham Dam, Coos County, New Hampshire 
Prepared by the Pembroke, Columbus, and West Trenton Publishing Service Centers.

For more information concerning this report, contact:

Office Chief

U.S. Geological Survey

New England Water Science Center

New Hampshire-Vermont Office

331 Commerce Way, Suite 2

Pembroke, NH 03275

dc_nh@usgs.gov

or visit our Web site at:

http://nh.water.usgs.gov 


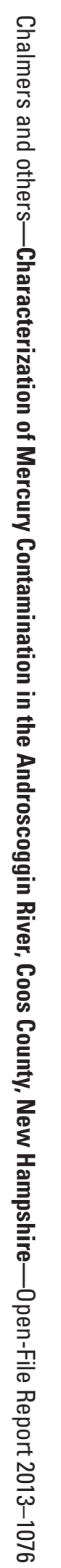

